\title{
ECOLOGICAL MONITORING AND COMPLIANCE PROGRAM FISCAL YEAR 2003 REPORT
}

\section{December 2003}

Prepared by

Bechtel Nevada

Ecological Services

P.O. Box 98521

Las Vegas, NV 89193-8521 


\title{
ECOLOGICAL MONITORING AND COMPLIANCE PROGRAM FISCAL YEAR 2003 REPORT
}

\author{
December 2003 \\ WORK PERFORMED UNDER \\ CONTRACT NO. DE-AC08-96NV11718 \\ Prepared for the \\ U.S. Department of Energy \\ National Nuclear Security Administration \\ Nevada Site Office \\ Environment, Safety, and Health Division \\ P.O. Box 98518 \\ Las Vegas, NV 89193-8518
}

Prepared by

\section{Bechtel Nevada}

Ecological Services

P.O. Box 98521

Las Vegas, NV 89193-8521 


\section{DISCLAIMER STATEMENT}

Reference herein to any specific commercial product, process, or service by trade name, trademark, manufacturer, or otherwise, does not necessarily constitute or imply its endorsement, recommendation, or favoring by the U.S. Government or any agency thereof or its contractors or subcontractors.

\section{AVAILABILITY STATEMENT}

Available for sale to the public from:

U.S. Department of Commerce

National Technical Information Service

5285 Port Royal Road

Springfield, VA 22161-0002

Telephone: 800-553-6847

Fax: 703-605-6900

E-mail: orders@ntis.gov

Online ordering: http://www.ntis.gov/ordering.htm

Available electronically at http://www.osti.gov/bridge

Available for a processing fee to the U.S. Department of Energy and its contractors, in paper, from:

U.S. Department of Energy

Office of Scientific and Technical Information

P.O. Box 62

Oak Ridge, TN 37831-0062

Telephone: 865-576-8401

Fax: 865-576-5728

E-Mail: reports@adonis.osti.gov 
THIS PAGE IS INTENTIONALLY LEFT BLANK 


\section{CONTENTS}

ACRONYMS AND ABBREVIATIONS $\ldots \ldots \ldots \ldots \ldots \ldots \ldots \ldots \ldots \ldots \ldots$ vii

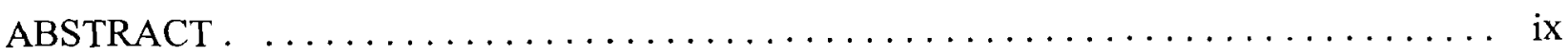

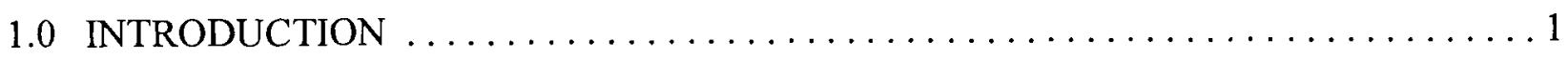

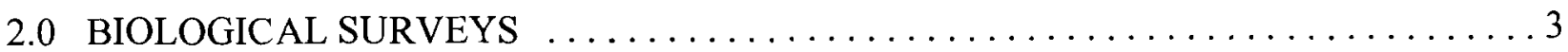

2.1 Sites Surveyed and Sensitive Species Observed $\ldots \ldots \ldots \ldots \ldots \ldots \ldots$

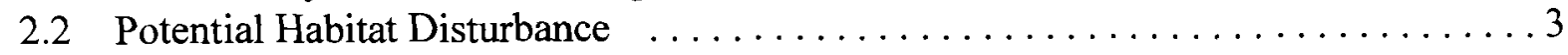

3.0 DESERT TORTOISE COMPLIANCE $\ldots \ldots \ldots \ldots \ldots \ldots \ldots \ldots \ldots \ldots \ldots \ldots$

3.1 Project Surveys and Compliance Documentation $\ldots \ldots \ldots \ldots \ldots \ldots \ldots \ldots$

3.2 Transect Surveys to Determine Relative Tortoise Abundance . . . . . . . . . 16

3.3 Proposed Habitat Revegetation Plan for Loss of Tortoise Habitat . . . . . . . . . 16

3.4 Coordination With Other Wildlife Agencies/Biologists $\ldots \ldots \ldots \ldots \ldots \ldots \ldots$

4.0 ECOSYSTEM MAPPING/DATA MANAGEMENT . . . . . . . . . . . . . 19

4.1 Acquisition of Orthophoto Digital Images $\ldots \ldots \ldots \ldots \ldots \ldots \ldots \ldots \ldots \ldots$

4.2 Adjustment of Mapped ELU Polygon Boundaries $\ldots \ldots \ldots \ldots \ldots \ldots \ldots$

4.3 Recalculation of Spatial Coordinates for ELUs $\ldots \ldots \ldots \ldots \ldots \ldots \ldots \ldots$

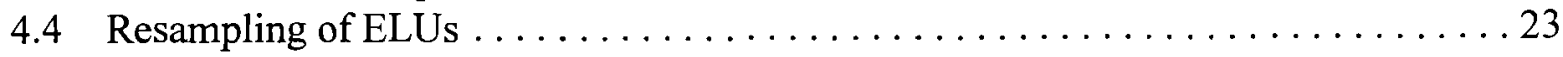

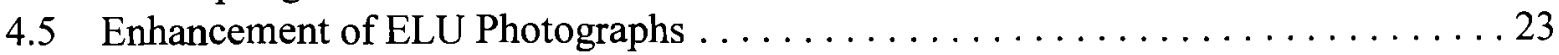

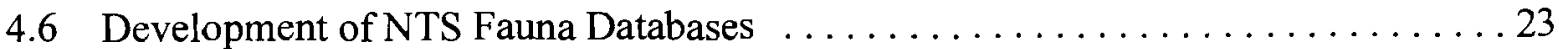

4.7 Coordination With Ecosystem Management Agencies/Scientists . . . . . . . . . 24

5.0 SENSITIVE SPECIES AND HABITAT MONITORING $\ldots \ldots \ldots \ldots \ldots \ldots \ldots \ldots . \ldots \ldots$

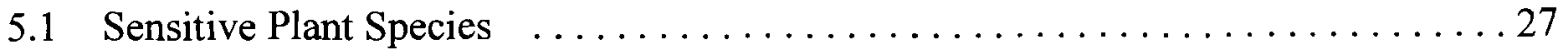

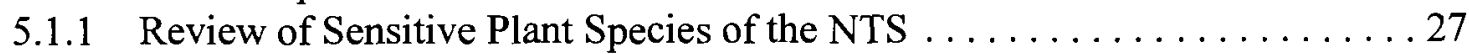

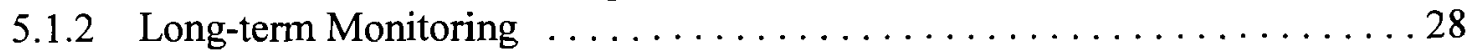

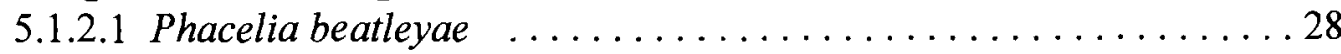

5.1 .2 .2 Astragalus funereus . . . . . . . . . . . . . . . . 33

5.1.3 Coordination With Natural Resource Agency Botanists . . . . . . . . 35

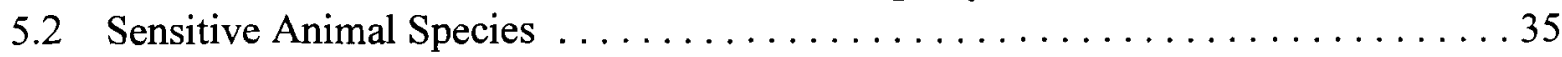

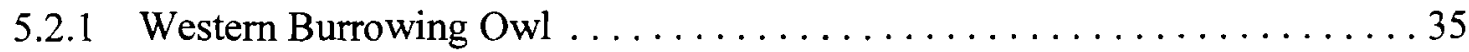

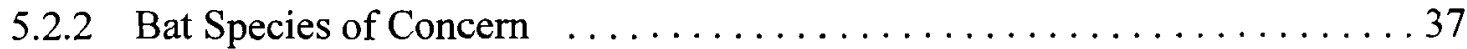

5.2.2.1 Bat Occurrence at Monitored Sites $\ldots \ldots \ldots \ldots \ldots \ldots \ldots \ldots$

5.2 .2 .2 Identification of Roost Sites . . . . . . . . . . . . . . . 42

5.2 .2 .3 Reported Day Roosts . . . . . . . . . . . . . . . . 45

5.2.2.4 Installation of Passive Acoustic Monitoring System . . . . . . . . 45

5.2.2.5 Coordination With Other Wildlife Agencies/Biologists . . . . . . 45

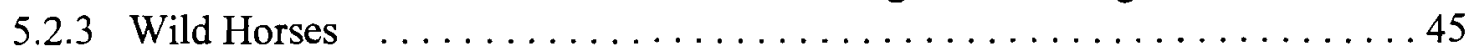

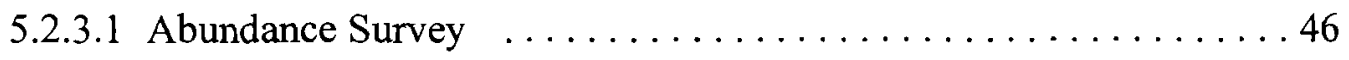

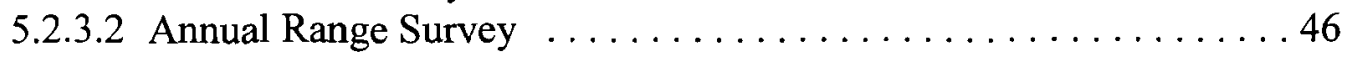




\section{CONTENTS}

5.2.3.3 Use of NTS Water Sources $\ldots \ldots \ldots \ldots \ldots \ldots \ldots \ldots \ldots \ldots$

5.2 .4 Raptors . ................................. 49

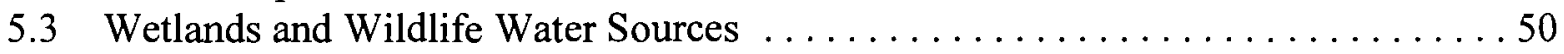

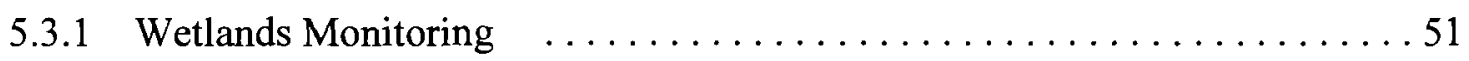

5.3 .2 Monitoring of Man-made Water Sources $\ldots \ldots \ldots \ldots \ldots \ldots \ldots \ldots \ldots$

6.0 HABITAT RESTORATION MONITORING . . . . . . . . . . . . . . . . . . . . 57

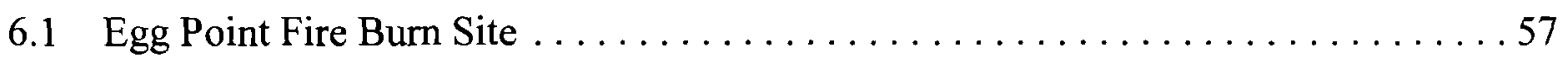

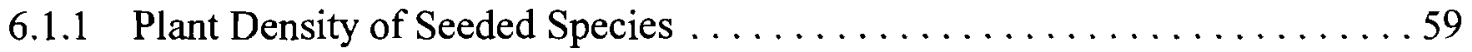

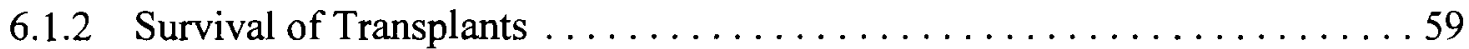

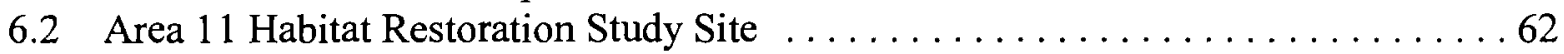

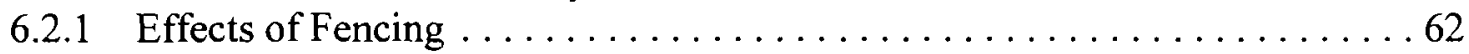

6.2 .2 Effects of Using Native Plant Material . . . . . . . . . . . . . 63

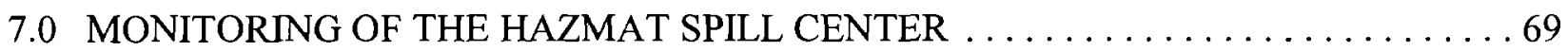

7.1 Task Description . . . . . . . . . . . . . . . . . . . . . . . . . . 69

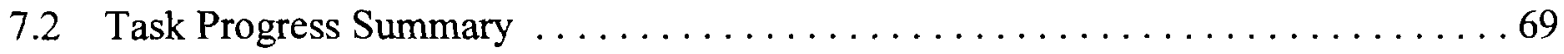

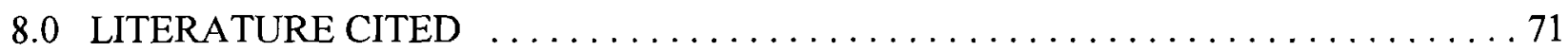

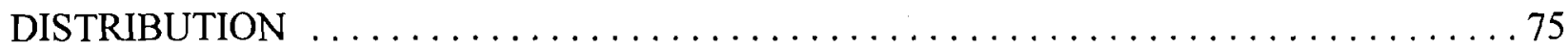

\section{List of Tables}

Table 1. Sensitive species that are protected under state or federal regulations which are known to occur on or adjacent to the NTS $\ldots \ldots \ldots \ldots \ldots \ldots \ldots \ldots \ldots$

Table 2. Summary of biological surveys conducted on the NTS during FY $2003 \ldots \ldots \ldots .8$

Table 3. Total acreage proposed for disturbance within important habitats in FY 2003

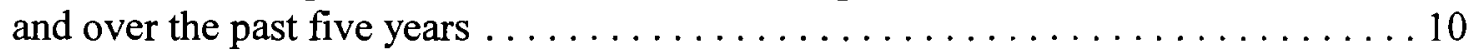

Table 4 Summary of tortoise compliance activities conducted by BN biologists

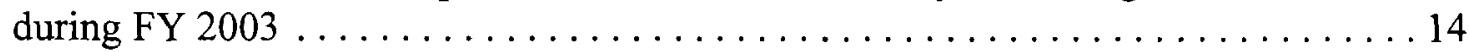

Table 5 Parameters and threshold values for desert tortoise monitoring on the NTS $\ldots \ldots 15$

Table 6. Characteristics of Phacelia beatleyae habitat on the NTS . . . . . . . . . . 32

Table 7. Characteristics of Astragalus funereus habitat on the NTS ............... 34

Table 8. Number of bats captured by sex and reproductive condition* (in italics) and number of electronic files of bat calls (regular font) at sites monitored in FY 2003.40

Table 9. Number of horse individuals observed on the NTS by age class, gender, and year since 1995 . . . . . . . . . . . . . . . . . . . . . . . . . . . . . . . 47

Table 10. Summary of NTS raptor mortality records from $1990-2003 \ldots \ldots \ldots \ldots \ldots . \ldots 50$

Table 11. Seasonal data from selected natural water sources on the NTS collected during FY 2003 


\section{List of Tables (Continued)}

Table 12. Wildlife observed at selected NTS natural water sources* (date of observation shown below name of water source) during FY $2003 \ldots \ldots \ldots \ldots \ldots \ldots$

Table 13. Plant densities on the upper and lower slopes of the Egg Point Fire

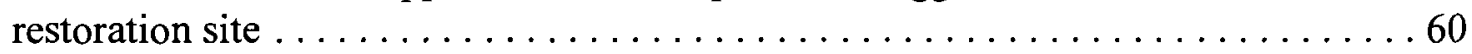

Table 14. Survival of transplants planted on the Egg Point Fire restoration site .........61

\section{List of Figures}

Figure 1. Biological surveys conducted on the NTS during FY $2003 \ldots \ldots \ldots \ldots \ldots$

Figure 2. Biological surveys conducted in important habitats of the NTS during FY $2003 \ldots 11$

Figure 3. Tortoise abundance transects sampled on the NTS in FY 2003 . . . . . . . . 17

Figure 4. Example of inaccurate registration of ELU polygons with orthophotos in Jackass Flats (upper photo) and accurate registration after spatial adjustments

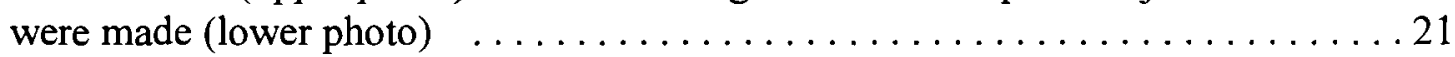

Figure 5. Example of old inaccurate locations of vegetation sampling transects in Jackass Flats (yellow) and their new accurate locations after corrections were made (red) . . 22

Figure 6. Data fields developed for the Mammals Database ................... 25

Figure 7. Data fields developed for the Photo Status Database .................. 25

Figure 8. Examples of digital image files of NTS wildlife collected for

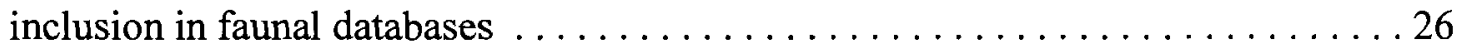

Figure 9. Phacelia beatleyae in flower east of Orange Blossom Road .............. 29

Figure 10. Typical habitat of Phacelia beatleyae on western slope of Skull Mountain in volcanic tuff on mid to upper slopes ........................ 29

Figure 11. Sensitive plant populations monitored on the NTS during FY $2003 \ldots \ldots \ldots .30$

Figure 12. Astragalus funereus with seed pods found on east slope of Shoshone Mountain,

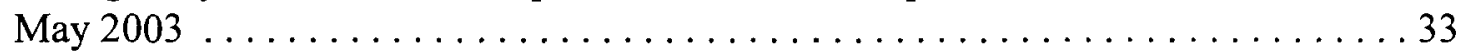

Figure 13. Typical habitat for Astragalus funereus on eastern slope of Shoshone Mountain . . 33

Figure 14. Known western burrowing owl distribution on the NTS .............. 36

Figure 15. Sites monitored for bat use on the NTS, roost site designations, and species present based on capture and acoustic monitoring data collected during FY 2003 . . 38

Figure 16. Sites monitored for bat use in the northeast portion of the NTS, roost site designations, and species present based on capture and acoustic monitoring data

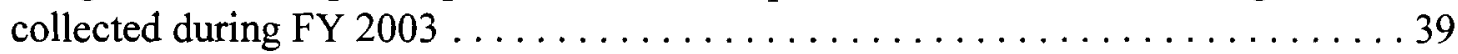

Figure 17. Female Townsend's big-eared bat captured at Oak Spring Middle Basin Adit 2,

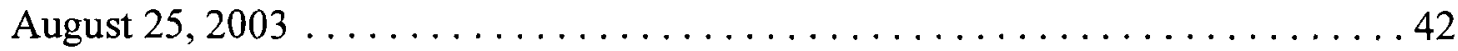

Figure 18. Anabat II system (on ground) and NightSight ${ }^{\mathrm{TM}}$ camera (on tripod) outside the

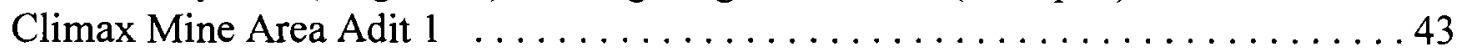

Figure 19. Feral horse sightings and horse sign observed on the NTS during FY $2003 \ldots \ldots 48$

Figure 20. Natural water sources on the NTS sampled during FY $2003 \ldots \ldots \ldots \ldots \ldots \ldots 2$

Figure 21. Man-made water sources monitored for wildlife use and mortality on the NTS

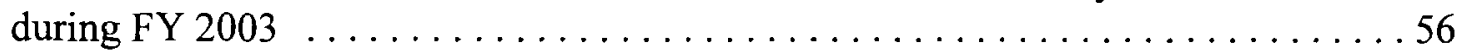

Figure 22. Aerial view of Egg Point Fire burn site on the lower east-facing slopes of

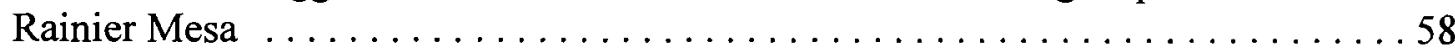




\section{List of Figures (Continued)}

Figure 23. Line transect sampling in June 2003 for plant density of seeded species along lower slopes of Egg Point Fire burn site . .................... 58

Figure 24. Coleogyne ramosissima seedling observed during line transect surveys at the

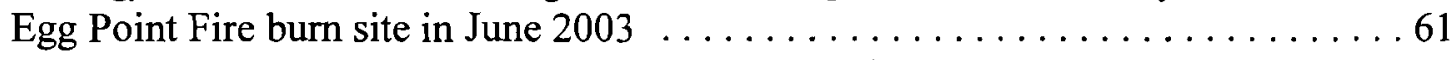

Figure 25. Container-grown transplant of Artemisia nova monitored June 2003 at the

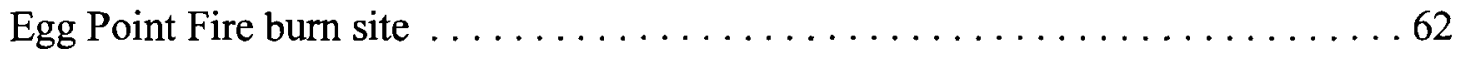

Figure 26. Survival of fenced and unfenced transplants at the Area 11 habitat restoration

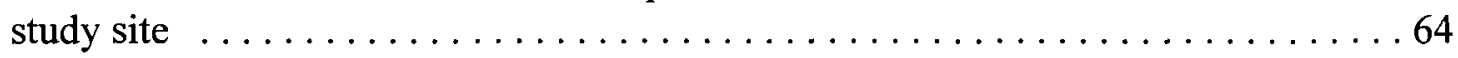

Figure 27. Shrub volume (in cubic millimeters) of fenced and unfenced transplants at the

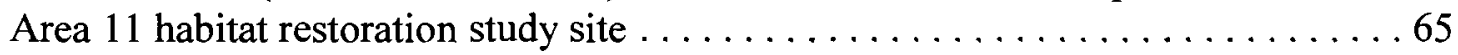

Figure 28. Percent survival of transplants grown from native and non-native seed sources at the Area 11 habitat reclamation study site $\ldots \ldots \ldots \ldots \ldots \ldots \ldots \ldots \ldots$

Figure 29. Shrub volume (in cubic millimeters) of transplants grown from native and non-native seeds at the Area 11 habitat restoration study site .68 


\section{ACRONYMS AND ABBREVIATIONS}

$\mathrm{BN}$

Bechtel Nevada

RSL

Remote Sensing Laboratory

CAU

Corrective Action Unit

CWA

Clean Water Act

DOE/NV

U.S. Department of Energy, Nevada Operations Office

DOQQ

Digital Orthophoto Quarter Quadrangle

EGIS

Ecological Geographic Information System

ELU

Ecological Landform Unit

EMAC

Ecological Monitoring and Compliance

ESA

Endangered Species Act

ESHD

Environment, Safety, and Health Division

$\mathrm{ft}$

Feet

FWS

U.S. Fish and Wildlife Service

FY

Fiscal Year

GPS

Global Positioning System

$\mathrm{km}$

Kilometers

$\mathrm{mi}$

Miles

$\mathrm{mm}$

Millimeter

NAD27

North American Datum of 1927

NAD83

North American Datum of 1983

NNHP

Nevada Natural Heritage Program

NNPS

Nevada Native Plant Society

NNSA/NSO

U.S. Department of Energy, National Nuclear Security Administration Nevada Site Office

$\mathrm{NNSA} / \mathrm{NV}$

U.S. Department of Energy, National Nuclear Security Administration Nevada Operations Office

NTS

Nevada Test Site

RMP

Resource Management Plan

USGS

U.S. Geological Survey

UTM

Universal Transverse Mercator

vii 
THIS PAGE IS INTENTIONALLY LEFT BLANK 


\section{ABSTRACT}

The Ecological Monitoring and Compliance program (EMAC), funded through the U.S. Department of Energy, National Nuclear Security Administration Nevada Site Office (NNSA/NSO), monitors the ecosystem of the Nevada Test Site (NTS) and ensures compliance with laws and regulations pertaining to NTS biota. This report summarizes the program's activities conducted by Bechtel Nevada (BN) during fiscal year 2003. Program activities included: (1) biological surveys at proposed construction sites, (2) desert tortoise compliance, (3) ecosystem mapping and data management, (4) sensitive species and unique habitat monitoring, (5) habitat restoration monitoring, and (6) biological monitoring at the HAZMAT Spill Center.

Sensitive species of the NTS include 22 plants, 2 reptiles, over 250 birds, and 18 mammals protected, managed, or considered sensitive as per state and federal regulations. The threatened desert tortoise is the only species on the NTS protected under the Endangered Species Act. Biological surveys for the presence of sensitive species and important biological resources they depend on were conducted for 18 projects. A total of 264 acres and 90 buildings scheduled for demolition were surveyed. Survey findings included 13 bird nests, 1 possible bat roost, 7 tortoise burrows, and 23 predator burrows.

Eleven of the 18 projects were in desert tortoise habitat. NNSA/NSO must comply with the terms and conditions of a permit (called a Biological Opinion) from the U.S. Fish and Wildlife Service (FWS) when conducting work in tortoise habitat. This year, only 3.11 acres of tortoise habitat were disturbed by fiscal year 2003 projects. To date, 215 acres of tortoise habitat have been disturbed on the NTS. No tortoises were found in or displaced from project areas, and no tortoises were accidentally injured or killed at project areas or along paved roads. In 1992, the U.S. Department of Energy, Nevada Operations Office (now NNSA/NSO) prepaid a required mitigation fee for the loss of 250 acres of tortoise habitat on the NTS. This year, a proposal was submitted to NNSA/NSO to revegetate disturbed tortoise habitat, which is allowed by the FWS, in lieu of paying a mitigation fee. The prepayment for the 35 remaining acres would be used as mitigation for acreage which cannot be released for revegetation or are of such poor quality that revegetation would be too costly or unsuccessful.

The ecosystem mapping and data management task of EMAC focused this year on updating and correcting geospatial data used for mapping vegetation associations on the NTS. New orthophoto digital aerial images of the NTS were acquired, adjustments of ecological landform unit (ELU) boundaries and field sampling locations were made, and selected ELUs were resampled to take new digital photographs and to collect shrub canopy cover data not sampled during previous years. A multi-year effort was started to collect wildlife data that will be spatially correlated with the mapped vegetation associations on the NTS. The computer databases for all geospatially-linked wildlife data were designed.

The annual review of the list of sensitive plants of the NTS was conducted. No changes to the list, containing 17 vascular and 5 non-vascular plants, were made. Two sensitive plants were selected for monitoring this year. Six known populations of Phacelia beatleyae (Beatley's phacelia) and three known populations of Astragalus funereus (black woollypod) were visited. 
P. beatleyae plants were found at only five of the six sites and at numbers $(130-800)$ reduced from those of previous years $(500-23,000)$. Only two fruiting $A$. funereus plants were found at one site, and only one seedling thought to be $A$. funereus was found at a second site. Previous reported population numbers have ranged from 16 to over 23,000 during visits to these three sites from 1991 to 1993 . Insufficient rainfall for growth and reproduction of these plants is believed responsible for the greatly reduced numbers and distribution of these two sensitive plants.

Field data collected over the past four years on the sensitive western burrowing owl was summarized this year into a topical report titled Ecology of the Western Burrowing Owl on the Nevada Test Site (DOE/NV/11717-701). It addresses the owl's distribution, burrow use, reproduction, activity patterns, and food habits.

Field monitoring of sensitive animals and important habitats of the NTS focused on bats, horses, and natural and man-made water sources. Seventeen potential bat roost sites and five water sources were monitored for bat activity. Bats were observed at all sites, and nine species, including four sensitive species were detected. One maternity roost and one day roost of the Townsend's big-eared bat (a sensitive species) were found in mine adits. Three day-roosts and eight night-roost/foraging sites used by multiple bat species were also identified.

Thirty adult horses and five foals were counted this year during the horse population census survey. Foal survival continues to be very low and no immigration of new adults was observed. Only eight adult males are known to be a part of the NTS horse population. The herd consists of one larger group (about 20 individuals) that spend summers west of the Eleana Range and one smaller group (7-10 individuals) that summer east of the Eleana Range on Yucca Flat. They probably intermix during the winter. Horses remain dependent on Captain Jack Spring and Camp 17 Pond during the summer. Except for Camp 17 pond, no man-made ponds or plasticlined sumps are used by horses.

Three incidents of raptor mortality were reported this year; one electrocuted red-tailed hawk, one electrocuted great-horned owl, and one road-killed western burrowing owl. No surveys were conducted this year to locate new or to monitor known raptor nests.

Thirteen wetlands and 54 man-made water sources were monitored for physical parameters and wildlife use. Signs of horse grazing and trampling of vegetation at four natural wetlands were observed. Over 550 birds representing 17 species were observed at wetlands which was an increase over last year. Over 30 dead mourning doves were observed at water sources. The majority were deaths believed to be caused by trichomoniasis, a disease of doves and pigeons caused by a protozoan that is spread by water and harmless to humans. No dead animals were observed this year in any plastic-lined sump.

NTS sites which have been revegetated with native seeds and transplants to control soil erosion, reduce the time-cycle of wildland fires, and reduce the invasion of non-native weed species, are periodically monitored under EMAC. The revegetation success of such sites are documented in order to learn from past methods and to develop better techniques for site restoration whenever NNSA/NSO is required to restore disturbances caused by project activities and wildland fires. This year, two sites were monitored: the 300-acre Egg Point Fire burn site and the historic Area 11 habitat restoration study site. At the burn site, line transects were sampled and density of 
seeded species was 0.85 plants $/ \mathrm{m}^{2}$ (plants per square meter) on upper slopes and 1.13 plants $/ \mathrm{m}^{2}$ on lower slopes. Of over 840 transplants sampled, 75 percent survived.

The Area 11 site was sampled to gather plant survival and volume data ten years after revegetation occurred. The status of transplants planted inside and outside of a fence was monitored as well as the status of transplants grown from shrub seeds collected on the NTS and from shrub seeds acquired commercially outside of Nevada. Hymenoclea salsola (white burrobrush) survival was not improved by fencing to protect against herbivory, and almost 98 percent of this species had died by the tenth year after planting. Shrub volumes were larger among fenced plants for three species, but the size of Larrea tridentata (creosote bush) did not appear to be improved by fencing. Generally, plants which survived outside the fence were orders of magnitude smaller in volume than those inside the fence. Percent survival was almost three times greater for transplants of Atriplex canescens (fourwing saltbush) grown from seed collected on the NTS. Use of local seed sources appeared to improve the survival of $A$. canescens transplants and the growth of both $L$. tridentata and $A$. canescens.

Chemical release test plans for five activities at the HAZMAT Spill Center on Frenchman Lake playa were reviewed. Seasonal sampling of downwind and upwind transects near the spill center was conducted to document baseline conditions of biota. No differences in vegetation or in the presence of animals and animal signs were noted along downwind versus upwind transects. 
THIS PAGE IS INTENTIONALLY LEFT BLANK 


\subsection{INTRODUCTION}

In accordance with DOE Order 450.1 "Environmental Protection Program", the Environment, Safety, and Health Division (ESHD) of the U.S. Department of Energy, National Nuclear Security Administration Nevada Site Operations Office (NNSA/NSO) requires ecological monitoring and biological compliance support for activities and programs conducted at the Nevada Test Site (NTS). Bechtel Nevada (BN) Ecological Services has implemented the Ecological Monitoring and Compliance (EMAC) program to provide this support. EMAC is designed to ensure compliance with applicable laws and regulations, delineate and define NTS ecosystems, and provide ecological information that can be used to predict and evaluate the potential impacts of proposed projects and programs on those ecosystems.

The ecological monitoring tasks conducted in fiscal year (FY) 2003 (October 1, 2002, through September 30, 2003) included: (1) Biological Surveys, (2) Desert Tortoise Compliance,

(3) Ecosystem Mapping/Data Management, (4) Sensitive Species and Habitat Monitoring, (5) Habitat Restoration Monitoring, and (6) HAZMAT Spill Center Monitoring. The sections of this report document work performed under these six program areas. 
THIS PAGE IS INTENTIONALLY LEFT BLANK 


\subsection{BIOLOGICAL SURVEYS}

Biological surveys are performed at proposed project sites where land disturbance will occur. The goal is to minimize adverse effects of land disturbance on sensitive plant and animal species, their associated habitat, and important biological resources. Sensitive species include those protected under state or federal regulations which are known or suspected to occur on the NTS (Table 1). Important biological resources include such things as cover sites, nest or burrow sites, roost sites, or water sources important to sensitive species. Survey reports are written to document species and resources found and to provide mitigation recommendations.

\subsection{Sites Surveyed and Sensitive Species Observed}

Biological surveys for 18 projects were conducted on or near the NTS (Figure 1, Table 2). For some of the projects, multiple sites were surveyed (Figure 1). A total of 264.37 acres was surveyed for the projects (Table 2). Eleven of the projects had sites within the range of the threatened desert tortoise (Gopherus agassizii). Sensitive species and important biological resources found included 13 bird nests and 1 possible bat roost within buildings scheduled for demolition, 1 inactive tortoise burrow, 12 inactive predator burrows, 6 tortoise burrows and 11 predator burrows which may have been active, and mature Joshua trees (Table 2). BN provided a written summary report of all survey findings and mitigation recommendations, where applicable (Table 2). All flagged burrows, except one inactive predator burrow, were avoided during construction activities. At two buildings scheduled for demolition, bird nests found during biological surveys were not removed by project personnel in time to prevent their use by breeding ravens in the spring. Demolition of these two buildings, one in Area 12 and one in Area 6 , was postponed. Biologists monitored the raven nests from April through June and informed project personnel when all young ravens (10 total) had fledged and the nests were empty.

\subsection{Potential Habitat Disturbance}

Four of the projects for which surveys were conducted were entirely on sites previously disturbed (e.g., industrial waste sites, building sites, existing borrow areas, existing well pads) (Table 2). Surveys are conducted at old industrial or nuclear weapons testing sites whenever vegetation has reinvaded a site or it is suspected that a sensitive species may be found. For example, tortoises may move through revegetated earthen sumps and may be concealed under vegetation during activities where heavy equipment is used. Preactivity surveys are conducted at such revegetated sites to ensure that tortoises are not in harm's way. Also, burrowing owls frequently inhabit burrows and culverts at disturbed sites, so preactivity surveys are conducted to ensure that adults, eggs, and nestlings in burrows are not harmed.

Fourteen projects were located either partially or entirely in areas that had not been previously disturbed. These projects have the potential to disturb a total of 82.45 acres. Over 30 acres of undisturbed land in Topopah Wash in Area 25 were surveyed (Project 03-16) for off-road driving of a vehicle equipped with radiation detection equipment, and over 20 acres of undisturbed land were surveyed in northern Yucca Flat in Area 8 where experimental soil stabilization plots will be constructed (Project 03-12) (Table 2). 
Table 1. Sensitive species that are protected under state or federal regulations which are known to occur on or adjacent to the NTS

\begin{tabular}{|c|c|c|}
\hline Flowering Plant Species & Common Names & Status $^{a}$ \\
\hline Arctomecon merriamii & White bearpoppy & SOC, W, IA \\
\hline Astragalus beatleyae & Beatley's milkvetch & $\mathrm{SOC}, \mathrm{T}, \mathrm{W}, \mathrm{A}$ \\
\hline Astragalus funereus & Black woollypod & SOC, W, A \\
\hline Astragalus oopherus var. clokeyanus & Clokey's egg milkvetch & SOC, W, A \\
\hline Camissonia megalantha & Cane Spring suncup & SOC, W, IA \\
\hline Cymopterus ripleyi var. saniculoides & Ripley's springparsley & SOC, W, IA \\
\hline Eriogonum concinnum & Darin's buckwheat & W, A \\
\hline Eriogonum heermannii var. clokeyi & Clokey's buckwheat & W, A \\
\hline $\begin{array}{l}\text { Frasera pahutensis or } F \text {. albicaulis var. } \\
\text { modocensis }\end{array}$ & $\begin{array}{l}\text { Pahute green gentian or Modoc } \\
\text { elkweed }\end{array}$ & SOC, W, IA \\
\hline Galium hilendiae ssp. kingstonense & Kingston Mountain bedstraw & SOC, W, IA \\
\hline Hulsea vestita ssp. inyoensis & Inyo hulsea & W, IA \\
\hline Ivesia arizonica var. saxosa & Whitefeather ivesia & W, A \\
\hline Lathyrus hitchcockianus & Hitchcock's peavine & W, A \\
\hline Penstemon pahutensis & Pahute penstemon & SOC, W, IA \\
\hline Phacelia beatleyae & Beatley's phacelia & $\mathrm{SOC}, \mathrm{W}, \mathrm{A}$ \\
\hline Phacelia mustelina & Weasel phacelia & W, IA \\
\hline Phacelia parishii & Parish's phacelia & SOC, W, IA \\
\hline \multicolumn{3}{|l|}{ Moss Species } \\
\hline Crossidiium seriatum & Seriate crossidium & $\mathrm{W}, \mathrm{E}$ \\
\hline Didymodon nevadensis & Gold Butte moss & $\mathrm{W}, \mathrm{E}$ \\
\hline Entosthodon planoconvexus & Planoconvex enthosthodon & $\mathrm{W}, \mathrm{E}$ \\
\hline Grimmia americana & American grimmia & $\mathrm{W}, \mathrm{E}$ \\
\hline Trichostomum sweetii & Sweet tricohostomum & $\mathrm{W}, \mathrm{E}$ \\
\hline \multicolumn{3}{|l|}{ Reptile Species } \\
\hline Gopherus agassizii & Desert tortoise & LT, NPT \\
\hline Sauromalus obesus & Chuckwalla & SOC \\
\hline \multicolumn{3}{|l|}{ Bird Species } \\
\hline Athene cunicularia hypugea & Western burrowing owl & $\mathrm{SOC}, \mathrm{P}$ \\
\hline Alectoris chukar & Chukar & $\mathrm{G}$ \\
\hline Aquila chrysaetos & Golden eagle & EA, $P$ \\
\hline
\end{tabular}


Table 1. (Continued)

\begin{tabular}{|c|c|c|}
\hline Bird Species & Common Name & Status $^{\mathrm{a}}$ \\
\hline Buteo regalis & Ferruginous hawk & $\mathrm{SOC}, \mathrm{P}$ \\
\hline Callipepla gambelii & Gambel's quail & G \\
\hline Charadrius montanus & Mountain plover & PT, P \\
\hline Chlidonias niger & Black tern & $\mathrm{SOC}$ \\
\hline Empidonax wrightii & Gray flycatcher & SOC \\
\hline Falco peregrinus anatum & American peregrine falcon & $<\mathrm{LE}, \mathrm{P}$ \\
\hline Haliaeetus leucocephalus & Bald eagle & LT-PD, EA, P \\
\hline Ixobrychus exillis hesperis & Western least bittern & $\mathrm{SOC}, \mathrm{P}$ \\
\hline Phainopepla nitens & Phainopepla & $\mathrm{SOC}$ \\
\hline Phasianus colchicus & Ring-necked pheasant & G \\
\hline Plegadis chihi & White-faced ibis & SOC, $\mathrm{P}$ \\
\hline \multicolumn{3}{|l|}{ Mammal Species } \\
\hline Antilocapra americana & Pronghorn antelope & G \\
\hline Corynorhinus townsendii pallescens & Townsend's big-eared bat & $\mathrm{SOC}$ \\
\hline Equus asinus & Burro & $\mathrm{H} \& \mathrm{~B}$ \\
\hline Equus caballus & Horse & $\mathrm{H} \& \mathrm{~B}$ \\
\hline Euderma maculatum & Spotted bat & SOC, NPT \\
\hline Felis concolor & Mountain lion & G \\
\hline Lynx rufus & Bobcat & F \\
\hline Myotis ciliolabrum & Small-footed myotis & SOC \\
\hline Myotis evotis & Long-eared myotis & SOC \\
\hline Myotis thysanodes & Fringed myotis & SOC \\
\hline Myotis volans & Long-legged myotis & SOC \\
\hline Myotis yumanensis & Yuma myotis & SOC \\
\hline Ovis canadensis nelsoni & Desert bighorn sheep & G \\
\hline Odocoileus hemionus & Mule deer & G \\
\hline Sylvilagus audubonii & Audubon's cottontail & G \\
\hline Sylvilagus nuttallii & Nuttall's cottontail & G \\
\hline Urocyon cinereoargenteus & Gray fox & F \\
\hline Vulpes velox macrotis & Kit fox & $\mathrm{F}$ \\
\hline
\end{tabular}


${ }^{\text {a }}$ Status Codes:

Endangered Species Act, U.S. Fish and Wildlife Service

LT - Listed Threatened

PT - Proposed for listing as Threatened

PD - Proposed for delisting

RA - Former Candidate or Proposed species; current information does not support proposal to list because species has proven more abundant or widespread, or to lack identifiable threats; a species of concern

$<\mathrm{LE}$ - Former listed endangered species

SOC - Species of concern

U.S. Department of Interior

H\&B - Protected under Wild Free Roaming Horses and Burros Act

EA - Protected under Bald and Golden Eagle Act

\section{State of Nevada Wildlife}

NPT - Protected

G - Regulated as game

F - Regulated as fur-bearer

P - Protected bird
State of Nevada Plants

W - On Nevada Natural Heritage Program's plant watch list

T - Nevada Treatened

E - Nevada Endangered

Long-term Plant Monitoring Status for the NTS (see Section 5.1.1 of this report)

A - Active

IA - Inactive

E - Evaluate

${ }^{b}$ Does not include all bird species that are protected by the Migratory Bird Treaty Act or by the state. Additionally, there are 26 birds which have been observed on the NTS, which are all protected by the state. 


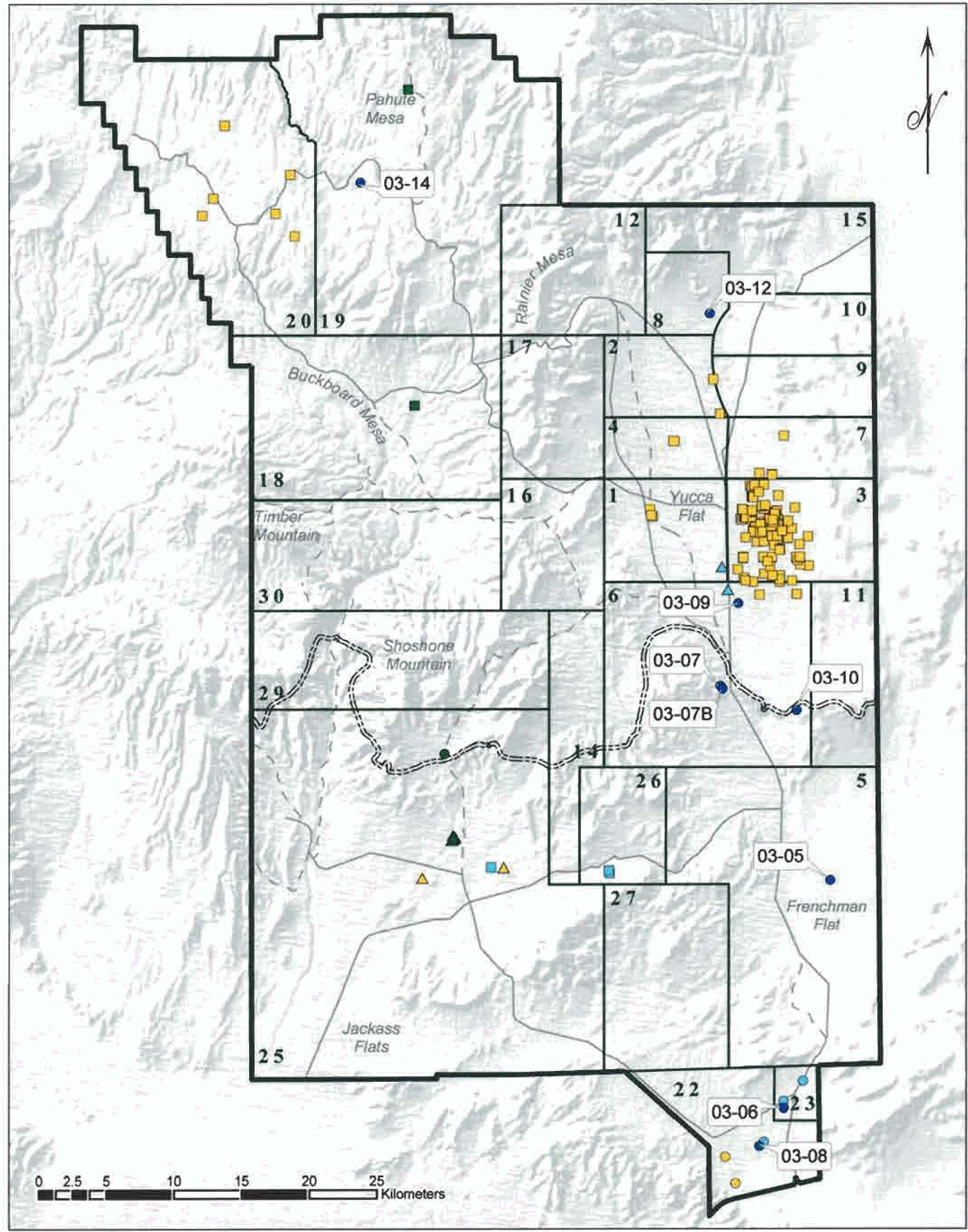

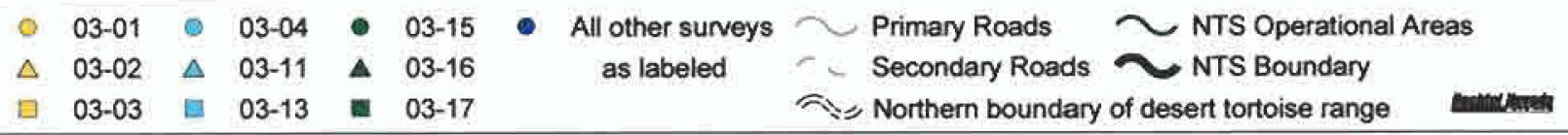

Figure 1. Biological surveys conducted on the NTS during FY 2003 
Table 2. Summary of biological surveys conducted on the NTS during FY 2003

\begin{tabular}{|c|c|c|c|c|c|}
\hline $\begin{array}{l}\text { Project } \\
\text { No. }\end{array}$ & Project & $\begin{array}{l}\text { Important } \\
\text { Species/ Resources } \\
\text { Found }\end{array}$ & $\begin{array}{c}\text { Area } \\
\text { Surveyed } \\
\text { (acres) }\end{array}$ & $\begin{array}{c}\text { Proposed Project } \\
\text { Area in } \\
\text { Undisturbed } \\
\text { Habitat (acres) }\end{array}$ & $\begin{array}{c}\text { Mitigation } \\
\text { Recommendations }\end{array}$ \\
\hline $03-01$ & Road and Culvert Repairs (2 sites) & $\begin{array}{l}\text { Inactive predator burrow, } \\
\text { tortoise burrow }\end{array}$ & 17.50 & 2.69 & Avoid flagged tortoise burrow \\
\hline 03-02 & $\begin{array}{l}\text { Area } 25 \text { Septic Systems and Underground } \\
\text { Discharge Point Closure (CAU* 262) (2 sites) }\end{array}$ & Inactive predator burrow & 2.25 & 1.11 & None \\
\hline 03-03 & Borehole Management (150 sites) & Four inactive predator burrows & 106.95 & 0 & None \\
\hline 03-04 & $\begin{array}{l}\text { Areas 6, 22, and } 23 \text { Tanks and Spill Sites (CAU } \\
330)(3 \text { sites) }\end{array}$ & None & 2.69 & 1.51 & None \\
\hline 03-05 & Area 5 Leachfield and Septic Tank (1 site) & None & 1.19 & 0.59 & None \\
\hline 03-06 & Area 23 Fire Drill (1 site) & None & 1.73 & 1.73 & None (PROJECT CANCELLED) \\
\hline $03-07^{* *}$ & Building Demolitions (55 sites) & $\begin{array}{l}\text { Ten bird nests, possible bat } \\
\text { roost }\end{array}$ & 3.73 & 0.05 & $\begin{array}{l}\text { Remove nests and periodically inspect } \\
\text { buildings to ensure nests are not rebuilt } \\
\text { prior to demolition; postpone } \\
\text { demolition until bat species identified. }\end{array}$ \\
\hline $03-08$ & $\begin{array}{l}\text { Area } 22 \text { Desert Rock Runway Lighting System } \\
\text { Renovation (1 site) }\end{array}$ & None & 20.46 & 0.5 & None \\
\hline 03-09 & Unicorn Subcritical Experiment ( 1 site) & None & 16.33 & 14.7 & None \\
\hline $03-10$ & Cleanup of Area 6 WSI Firing Range (1 site) & $\begin{array}{l}\text { Six predator burrows, inactive } \\
\text { tortoise burrow, Joshua trees }\end{array}$ & 10.82 & 3.21 & Avoid flagged burrows and Joshua trees \\
\hline $03-11$ & Surface Laid Power Cables ( 2 sites) & None & 3.31 & 0.44 & None \\
\hline $03-12$ & Legacy Rehabilitation Demarcation - SMOKEY & $\begin{array}{l}\text { Seven inactive predator } \\
\text { burrows }\end{array}$ & 20.76 & 20.76 & None \\
\hline $03-13$ & Cleanup of R-MAD Yard and Port Gaston (3 sites) & None & 2.12 & 0.74 & None \\
\hline $03-14$ & CHANCELLOR Post-Shot Drillback & None & 2.27 & 0.91 & None \\
\hline 03-15 & $\begin{array}{l}\text { Cleanup of Topopah Wash Military Firing Range } \\
\text { (2 sites) }\end{array}$ & None & 3.78 & 0 & None \\
\hline $03-16$ & $\begin{array}{l}\text { Area } 25 \text { Contaminated Wash and Land Parcels } \\
\text { near Test Cell C (CAU 259) (10 sites) }\end{array}$ & $\begin{array}{l}\text { Five tortoise burrows, five } \\
\text { predator burrows }\end{array}$ & 43.32 & 33.51 & Avoid all burrows \\
\hline
\end{tabular}

${ }^{*} \mathrm{CAU}=$ Corrective Action Unit

**Building locations not shown on Figure 1. 
Table 2. (Continued)

\begin{tabular}{|c|c|c|c|c|c|}
\hline $\begin{array}{l}\text { Project } \\
\text { Number }\end{array}$ & Project & $\begin{array}{l}\text { Important } \\
\text { Species/Resources } \\
\text { Found }\end{array}$ & $\begin{array}{c}\text { Area } \\
\text { Surveyed } \\
\text { (acres) }\end{array}$ & $\begin{array}{c}\text { Proposed Project } \\
\text { Area in } \\
\text { Undisturbed } \\
\text { Habitat (acres) } \\
\end{array}$ & $\begin{array}{c}\text { Mitigation } \\
\text { Recommendations }\end{array}$ \\
\hline $03-17$ & Areas 18 and 19 Borrow Pit Reactivation (2 sites) & None & 5.16 & 0 & None \\
\hline \multirow[t]{2}{*}{$03-18$} & Building Demolitions ( 35 sites) & $\begin{array}{l}\text { Three bird nests, bird perch } \\
\text { sites }\end{array}$ & 0 & 0 & $\begin{array}{l}\text { Demolish buildings before February } \\
2004 \text { to avoid reuse of nests in the } \\
\text { spring. }\end{array}$ \\
\hline & Total & & 264.37 & 82.45 & \\
\hline
\end{tabular}


Four of the 14 projects that will cause new disturbances occur in areas designated as important habitat (Figure 2). During vegetation mapping of the NTS, Ecological Landform Units (ELUs) were evaluated and some were identified as Pristine (having few man-made disturbances), Unique (containing uncommon biological resources such as a natural wetland), Sensitive (containing vegetation associations which recover very slowly from direct disturbance), and Diverse (having high plant species diversity) (DOE/NV, 1998). A single ELU could be classified as more than one type of important habitat. Figure 2 shows the distribution of these important habitats which were ranked so that pristine habitat overlays unique, which then overlays sensitive, which then overlays diverse habitat.

The expected acreage to be disturbed in sensitive habitat due to FY 2003 projects is 24.48 (Table 3). No pristine, unique, or diverse habitats will be disturbed by construction of FY 2003 projects. Since FY 1999, a tally of all acreage proposed for disturbance within important habitats has been kept (Table 3). This tally may be used in the future to estimate the area and rate of establishment of invasive species into these habitats. Land-disturbing activities are known to cause the spread of invasive species such as Bromus rubens (red brome) into areas of the NTS where they have not previously occurred. Such non-native weeds can degrade important habitats by decreasing plant biodiversity and increasing the risk and spread of wildfires. The monitoring and control of invasive plants on federal lands is encouraged under Executive Order 13112, Invasive Species.

Table 3. Total acreage proposed for disturbance within important habitats in FY 2003 and over the past five fiscal years

\begin{tabular}{|c|c|c|c|c|c|}
\hline $\begin{array}{l}\text { Project } \\
\text { No. }\end{array}$ & Project Name & $\begin{array}{l}\text { Pristine } \\
\text { Habitat }\end{array}$ & $\begin{array}{r}\text { Unique } \\
\text { Habitat }\end{array}$ & $\begin{array}{l}\text { Sensitive } \\
\text { Habitat }\end{array}$ & Diverse Habitat \\
\hline $03-01$ & Road and Culvert Repairs (2 sites) & 0 & 0 & 2.69 & 0 \\
\hline $03-05$ & Area 5 Leachfield and Septic Tank & 0 & 0 & 0.59 & 0 \\
\hline $03-11$ & $\begin{array}{l}\text { Surface Laid Power Cables (U1g-U1h } \\
\text { Complex site) }\end{array}$ & 0 & 0 & 0.44 & 0 \\
\hline \multirow[t]{3}{*}{$03-12$} & $\begin{array}{l}\text { Legacy Rehabilitation Demarcation - } \\
\text { SMOKEY }\end{array}$ & 0 & 0 & 20.76 & 0 \\
\hline & Total FY 2003 & $\mathbf{0}$ & $\mathbf{0}$ & 24.48 & $\mathbf{0}$ \\
\hline & Total $1999-2003$ & 18.95 & 19.85 & 213.31 & 193.85 \\
\hline
\end{tabular}




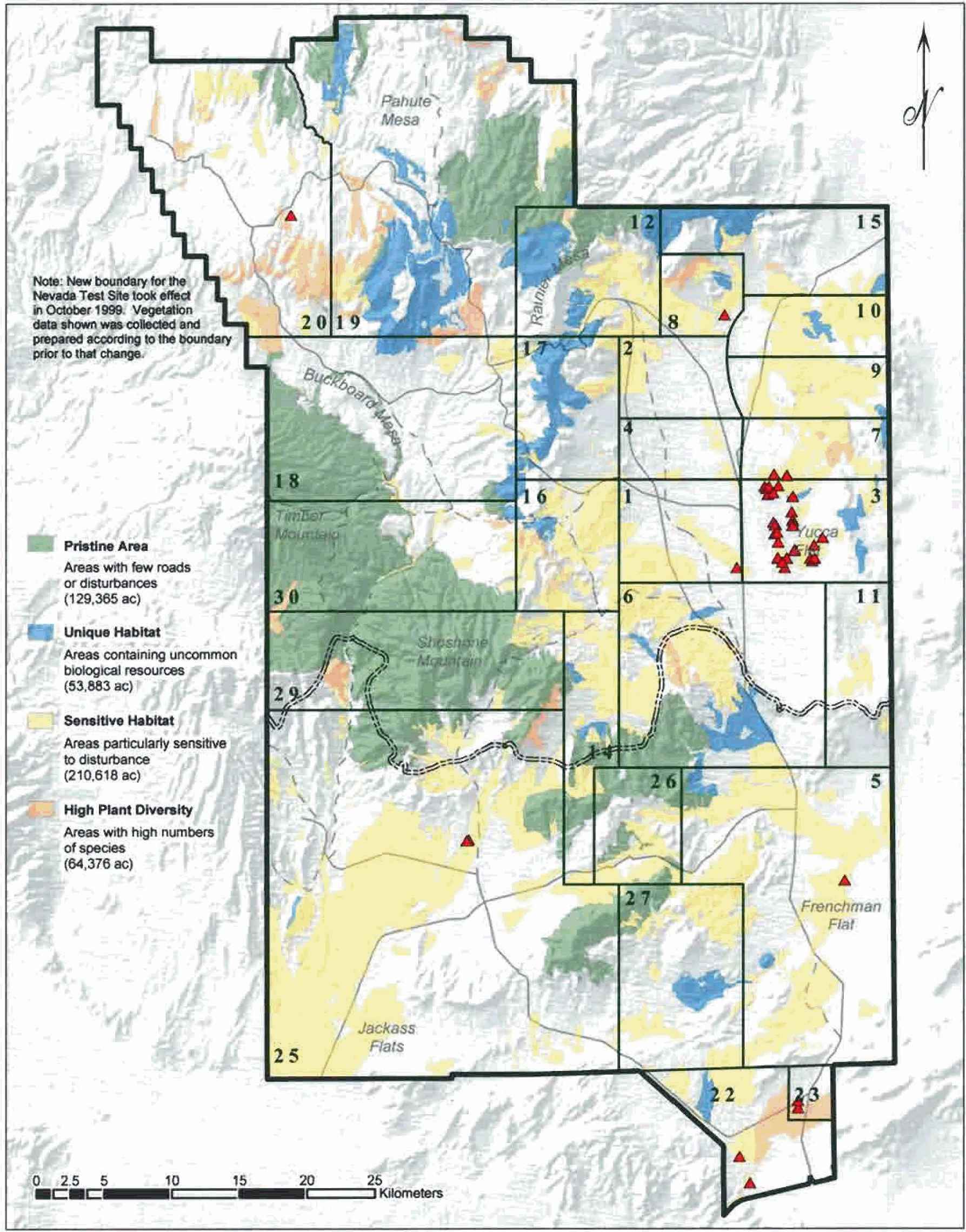
$\triangle$ Biological survey
Primary roads
Fs Northern boundary of desert tortoise range
Secondary roads

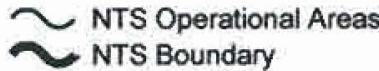


THIS PAGE IS INTENTIONALLY LEFT BLANK 


\subsection{DESERT TORTOISE COMPLIANCE}

The desert tortoise occurs within the southern one-third of the NTS. This species is listed as threatened under the Endangered Species Act (ESA). In December 1995, NNSA/NSO completed consultation with the U.S. Fish and Wildlife Service (FWS) concerning the effects of NNSA/NSO activities, as described in the Final Environmental Impact Statement for the Nevada Test Site and Off-Site Locations in the State of Nevada (DOE/NV, 1996), on the desert tortoise. A final Biological Opinion (Opinion) (FWS, 1996) was received from the FWS in August 1996. The Opinion concluded that the proposed activities on the NTS were not likely to jeopardize the continued existence of the Mojave population of the species and that no critical habitat would be destroyed or adversely modified. All terms and conditions listed in the Opinion must be followed when activities are conducted within the range of the desert tortoise on the NTS.

The Desert Tortoise Compliance task of EMAC was developed to implement the terms and conditions of the Opinion, to document compliance actions taken by NNSA/NSO, and to assist NNSA/NSO in FWS consultations. The terms and conditions that were implemented by BN staff biologists in FY 2003 included (a) conducting clearance surveys at project sites within one to seven days from the start of project construction, (b) ensuring that environmental monitors are on-site during heavy equipment operation, and (c) preparing an annual compliance report submitted to the FWS.

\subsection{Project Surveys and Compliance Documentation}

Biologists conducted desert tortoise clearance surveys prior to ground-disturbing activities for 11 proposed projects at 27 sites (Table 4, Figure 1). All but one of the project sites (Project Number 03-16, off-road driving routes in Topopah Wash) were in, or immediately adjacent to, existing facilities and disturbances. These 27 sites do not include the locations of any buildings surveyed for bird nests and bat roosts (Projects 03-07 and 03-18) which happened to be in the Mercury or $\mathrm{CP}$ complex within the geographic range of the desert tortoise. No viable tortoise habitat was found at these building sites and their locations are not shown on Figure 1.

One inactive tortoise burrow and six tortoise burrows which may be active were found during tortoise clearance surveys (Table 2). For Project 03-16, over 30 acres of undisturbed land in Topopah Wash in Area 25 was surveyed for off-road driving of a vehicle equipped with radiation detection equipment. A biologist walked in front of the vehicle and all tortoise burrows observed were avoided. No loss of tortoise habitat occurred as a result of the off-road driving. BN Ecological Services ensured that on-site construction monitoring was conducted by a designated environmental monitor at all sites where clearance surveys were performed.

Post-activity surveys to quantify the acreage of tortoise habitat actually disturbed were conducted for five FY 2003 projects (Table 4). Post-activity surveys were not conducted if viable tortoise habitat was not found within the project area boundaries during the clearance survey and if the environmental monitor documented that the project stayed within its proposed boundaries. This fiscal year, a total of 3.11 acres of disturbed tortoise habitat were documented (Table 4). 
Table 4. Summary of tortoise compliance activities conducted by BN biologists during FY 2003

\begin{tabular}{|c|c|c|c|}
\hline $\begin{array}{l}\text { Project } \\
\text { Number }\end{array}$ & Project & Compliance Activities & $\begin{array}{l}\text { Tortoise Habitat } \\
\text { Disturbed (acres) }\end{array}$ \\
\hline $03-01$ & Road and Culvert Repairs (2 sites) & $\begin{array}{l}100 \text { percent-coverage clearance survey, } \\
\text { flagged tortoise burrow avoided, } \\
\text { post-activity survey }\end{array}$ & 2.27 \\
\hline $03-02$ & $\begin{array}{l}\text { Area } 25 \text { Septic Systems and } \\
\text { Underground Discharge Point Closure } \\
\text { (CAU 262) (2 sites) }\end{array}$ & $\begin{array}{l}100 \text { percent-coverage clearance survey, } \\
\text { post-activity survey }\end{array}$ & 0.14 \\
\hline 03-04 & $\begin{array}{l}\text { Areas 6, 22, and } 23 \text { Tanks and Spill Sites } \\
\text { (CAU 330) (3 sites) }\end{array}$ & $\begin{array}{l}100 \text { percent-coverage clearance survey, } \\
\text { post-activity survey }\end{array}$ & 0.61 \\
\hline $03-05$ & $\begin{array}{l}\text { Area } 5 \text { Leachfield and Septic Tank (1 } \\
\text { site) }\end{array}$ & $\begin{array}{l}\text { Voluntary } 100 \text { percent-coverage clearance } \\
\text { survey, site is in area exempt from terms } \\
\text { and conditions of Biological Opinion }\end{array}$ & $\mathrm{N} / \mathrm{A}^{\mathrm{l}}$ \\
\hline $03-06$ & Area 23 Fire Drill (1 site) & 100 percent-coverage clearance survey & $\begin{array}{c}0 \\
\text { Project cancelled }\end{array}$ \\
\hline $03-07^{*}$ & $\begin{array}{l}\text { Building Demolitions - road widening at } \\
1 \text { site) }\end{array}$ & $\begin{array}{l}100 \text { percent-coverage clearance survey, } \\
\text { post-activity survey }\end{array}$ & 0.09 \\
\hline $03-08$ & $\begin{array}{l}\text { Area } 22 \text { Desert Rock Runway Lighting } \\
\text { System Renovation ( } 1 \text { site) }\end{array}$ & 100 percent-coverage survey & $\mathrm{TBD}^{2}$ \\
\hline $03-10$ & $\begin{array}{l}\text { Cleanup of Area } 6 \text { WSI Firing Range } \\
\text { (1site) }\end{array}$ & 100 percent-coverage clearance survey & 0 \\
\hline $03-13$ & $\begin{array}{l}\text { Cleanup of R-MAD Yard and Port } \\
\text { Gaston ( } 3 \text { sites) }\end{array}$ & $\begin{array}{l}100 \text { percent coverage clearance survey, } \\
\text { post-activity survey }\end{array}$ & 0 \\
\hline $03-15$ & $\begin{array}{l}\text { Cleanup of Topopah Wash Military } \\
\text { Firing Range ( } 2 \text { sites) }\end{array}$ & 100 percent- coverage clearance survey & 0 \\
\hline \multirow[t]{2}{*}{$03-16$} & $\begin{array}{l}\text { Area } 25 \text { Contaminated Wash and Land } \\
\text { Parcels near Test Cell C (CAU 259) (10 } \\
\text { sites) }\end{array}$ & $\begin{array}{l}\text { Off-road driving route surveys, avoided all } \\
\text { observed burrows while driving, } 100 \\
\text { percent-coverage clearance surveys at } \\
\text { drilling and sampling sites }\end{array}$ & $\begin{array}{l}\text { TBD at drilling and } \\
\text { sampling sites }\end{array}$ \\
\hline & & Total & 3.11 \\
\hline$V / A=N$ & $\begin{array}{l}\text { plicable } \\
\text { letermined }\end{array}$ & & \\
\hline
\end{tabular}


In January, BN submitted to ESHD the annual report that summarized tortoise compliance activities conducted on the NTS from January 1 through December 31, 2002. This report, required under the Opinion, contains (a) the location and size of land disturbances that occurred within the range of the desert tortoise during the reporting period; (b) the number of desert tortoises injured, killed, or removed from project sites; (c) a map showing the location of all tortoises sighted on or near roads on the NTS; and (d) a summary of construction mitigation and monitoring efforts.

Compliance with the Opinion will ensure that the two goals of the Nevada Test Site Resource Management Plan (DOE/NV, 1998) are being met; namely, that the desert tortoise is protected on the NTS and that the cumulative impacts on this species are minimized. In the Opinion, the FWS has determined that the "incidental take"1 of tortoises on the NTS and the cumulative acreage of tortoise habitat disturbed on the NTS are parameters to be measured and monitored annually. During this fiscal year, the threshold levels established by the FWS for these parameters were not exceeded (Table 5). No desert tortoises were accidentally injured or killed, nor were any captured or displaced from project sites.

Table 5. Parameters and threshold values for desert tortoise monitoring on the NTS

\begin{tabular}{|c|c|c|c|}
\hline Monitored Parameter & $\begin{array}{l}\text { Threshold } \\
\text { Value }\end{array}$ & Adaptive Management Action & $\begin{array}{l}\text { FY } 2003 \text { Value of } \\
\text { Monitored } \\
\text { Parameter }\end{array}$ \\
\hline $\begin{array}{l}\text { Number of tortoises accidentally injured or killed as a } \\
\text { result of NTS activities per year }\end{array}$ & 3 & $\begin{array}{l}\text { Reinitiate consultation with } \\
\text { FWS }\end{array}$ & 0 \\
\hline $\begin{array}{l}\text { Number of tortoises captured and displaced from NTS } \\
\text { project sites per year }\end{array}$ & 10 & $\begin{array}{l}\text { Reinitiate consultation with } \\
\text { FWS }\end{array}$ & 0 \\
\hline $\begin{array}{l}\text { Number of tortoises taken in form of injury or } \\
\text { mortality on paved roads on the NTS by vehicles other } \\
\text { than those in use during a project }\end{array}$ & Unlimited & $\begin{array}{l}\text { Supplemental employee } \\
\text { education and bulletins }\end{array}$ & 0 \\
\hline $\begin{array}{l}\text { Number of total acres of desert tortoise habitat } \\
\text { disturbed during NTS project construction since } 1992\end{array}$ & 3,015 & $\begin{array}{l}\text { Reinitiate consultation with } \\
\text { FWS }\end{array}$ & 215 \\
\hline
\end{tabular}

${ }^{1}$ To "take" a threatened or endangered species, as defined by the ESA, is to harass, harm, pursue, hunt, shoot, wound, kill, trap, capture or collect, or attempt to engage in any such conduct. 


\subsection{Transect Surveys to Determine Relative Tortoise Abundance}

The current Opinion includes a tortoise abundance map which delineates areas of none-to-verylow, low, and moderate tortoise abundance (Figure 3). According to the Opinion, tortoise clearance surveys and on-site construction monitoring are optional in none-to-very-low abundance areas, but are required in areas of higher or unknown tortoise abundance. The Opinion allows for updates of this map as better data become available. In FY 1996 and 1997, 209 ELUs of unknown tortoise abundance were sampled and the abundance map in the Opinion was updated in January 1998. There still remains many areas, predominantly mountain ranges including Skull Mountain, Little Skull Mountain, Red Mountain, and Mercury Ridge, that have not yet been sampled. The increase this year in winter and summer rains compared to the past several years was expected to trigger increased above-ground activity of tortoises and increase the likelihood of observing tortoises and their sign along transects within occupied habitat. Therefore, during August, BN biologists began to sample more ELUs of unknown tortoise abundance.

Twenty-eight transects totaling $54.8 \mathrm{~km}$ (kilometers) (34.0 mi [miles]) were sampled (Figure 3). The transects occurred within 25 ELUs. All tortoises and their sign observed on each transect were recorded using the methods of Berry and Nicholson (1984). More transects within other un-sampled ELUs will continue to be surveyed in 2003 prior to November when the majority of desert tortoises become inactive above ground. Data analysis of survey results will occur next fiscal year for transects sampled this August.

\subsection{Proposed Habitat Revegetation Plan For Loss of Tortoise Habitat}

Mitigation for the loss of tortoise habitat is required under the terms and conditions of the Opinion. The Opinion requires NNSA/NSO to perform either of two mitigation options: 1) pre-pay Clark County $\$ 648$ for each acre of habitat disturbed, or 2) revegetate disturbed habitat following specified criteria. Since 1992, NNSA/NSO has been using the balance of $\$ 81,000$ that NNSA/NSO deposited into a Clark County fund to pre-pay for the future disturbance of 250 acres of tortoise habitat on the NTS. This fund is almost depleted and it is necessary to develop a strategy for funding and implementing habitat mitigation so that work in tortoise habitat may continue without interruption in the future.

BN biologists submitted a letter to NNSA/NSO which proposed a new plan to revegetate tortoise habitat whenever it is reasonable and prudent to fund. The plan proposed that the pre-paid Clark County fund continue to be used for selected sites. These selected sites would be those which will not be released from project use in the near future and therefore cannot be revegetated, and those abandoned sites in very poor habitat where revegetation is expected to be costly or unsuccessful. BN Ecological Services plans to prepare and submit a draft habitat revegetation plan to NNSA/NSO and then to the FWS for their approval next fiscal year.

\subsection{Coordination With Other Wildlife Agencies/Biologists}

In late September 2002, a BN biologist accompanied a team of volunteer biologists, led by Phil Medica of the Southern Nevada Field Office of the FWS to Rock Valley in Area 25. The team captured, measured, and weighed desert tortoises within three 21 -acre circular enclosures in Rock 


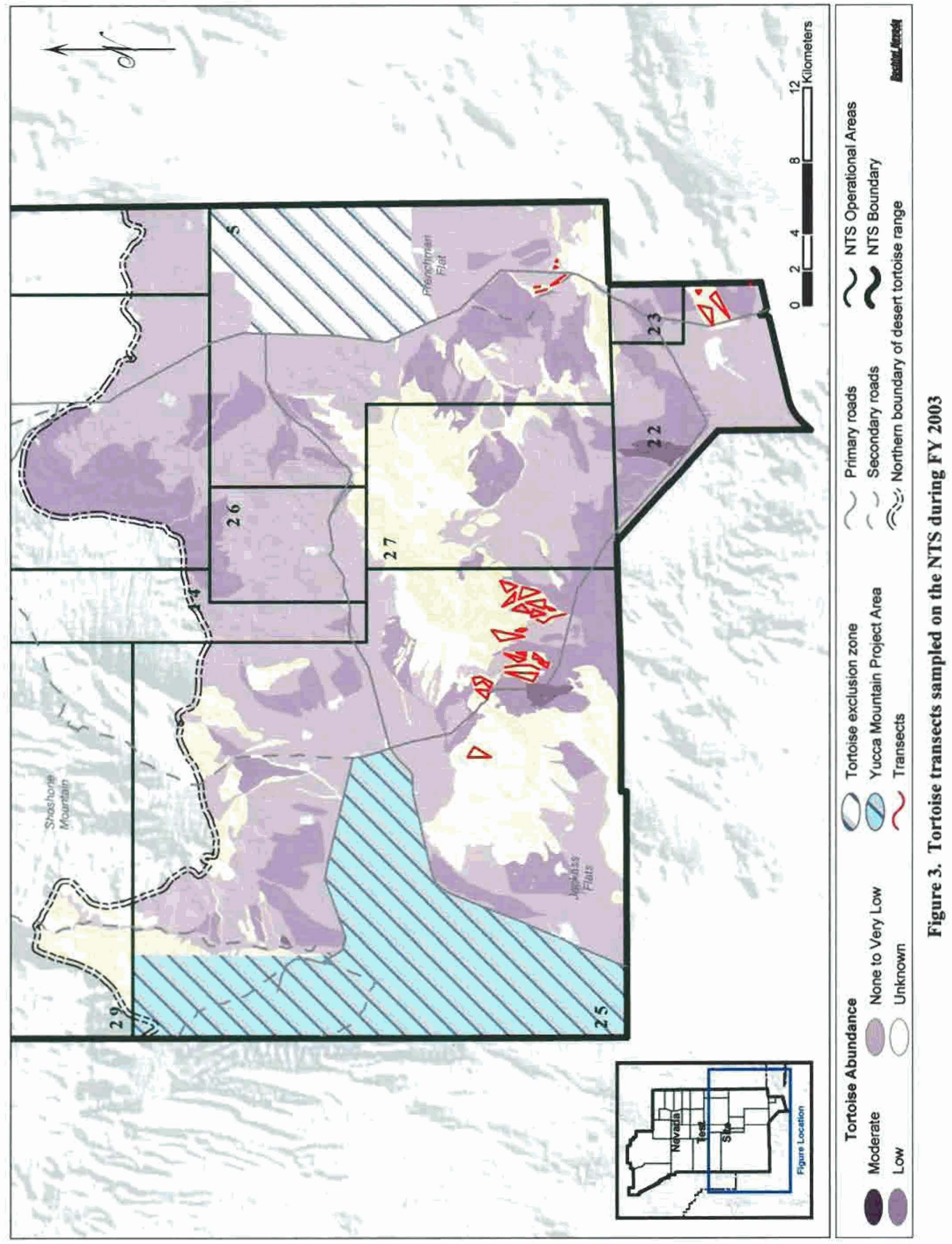


Valley. The circular enclosures were constructed during 1962-1963 to study the effects of chronic, low-level ionizing radiation on the desert flora and fauna. Over the past decades, at least 24 tortoises have been found, individually marked, and periodically measured. There are approximately 18 adult tortoises remaining in the enclosures. Results of the sampling trip were reported to BN biologists this fiscal year in November 2002. Thirteen of the 18 tortoises were captured, measured, and weighed. They included two immature, seven adult male, and four adult female tortoises. They are considered captive by the FWS and are not protected under the 1996 Biological Opinion. BN biologists assist in locating and photographing these tortoises each year. The annual census represents the longest continuous study of growth in wild desert tortoises. 


\subsection{ECOSYSTEM MAPPING/DATA MANAGEMENT}

In FY 1996, Ecological Services began to map wildlife and plant habitats of the NTS. Selected biotic and abiotic habitat features were collected within field mapping units called Ecological Landform Units (ELUs). ELUs are landforms with visually similar vegetation, soil types (Peterson, 1981), slope, and hydrology. Boundaries of the ELUs were defined using aerial photographs, satellite imagery, and field confirmation. ELUs are considered to be the most feasible mapping unit by which sensitive plant and animal habitats can be described. In December 2000, a topical report describing the classification of habitat types was published and distributed (Ostler et al., 2000). Ten vegetation alliances and 20 associations were recognized as occurring on the NTS. In FY 2003, a multi-year effort was started to identify and collect wildlife data that can be spatially correlated with the vegetation alliances and associations. This year efforts were focused on the following tasks in support of ecosystem mapping and data management of all NTS geospatial ecological data:

- Acquire new orthophoto digital images as photo base-maps for NTS ecosystems

- Adjust boundaries of ELU map polygons to correlate with the new orthophoto base images

- Recalculate spatial coordinates for vegetation sampling transects within 1,600 ELUs

- Resample ELUs to obtain shrub abundance, canopy cover, site photos, and to document plant species composition in the lower one-third of the NTS

- Digitally enhance existing photographs of ELUs

- Design databases and continue data entry for NTS faunal distribution data to be linked to ELU habitat data

\subsection{Acquisition of Orthophoto Digital Images}

Aerial photos of the NTS were acquired in August and September of 1994 by the Remote Sensing Laboratory (RSL). The missions were flown at 488 meters ( $\mathrm{m})(16,000 \mathrm{ft}$ [feet]) above ground using normal and infrared color film. More than 1,000 photos were taken. Each photo (approximately 1:24,000 scale in size) showed approximate $6.2 \mathrm{~km}$ (4 mi) on a side. These images were digitally scanned, cut, and combined into a photo atlas of the NTS comprising more than 240 photo maps. This photo atlas (DOE/NV, Undated) provided topographic details sufficient to identify major land forms and was used by BN biologists to identify potential ELUs that were used in the mapping of vegetation as described by Ostler et al. (2000). These images were never ortho-photographically rectified and contained small spatial errors due to variations in the airplane's position at the instant the photo was taken.

In the summer of 1998 , new aerial photographs were acquired by RSL. These new photographs (approximately 1:40,000 scale in size) were orthophoto-graphically rectified to produce a collection of 528 geometrically corrected aerial-photo images. These images were obtained by Ecological Services from RSL as digital orthophoto quarter-quadrangle (3.75-minutes of latitude by 3.75-minutes of longitude) images (DOQQs) cast on the Universal Transverse Mercator (UTM) projection using North American Datum of 1983 (NAD83). BN biologists obtained 151 DOQQs this year for use in habitat mapping. These new DOQQs will provide the best resolution 
for landscape features and exceed the photo details of previous LANDSAT and SPOT images that were used for previously-published habitat maps (Ostler, et. al., 2000).

\subsection{Adjustment of Mapped ELU Polygon Boundaries}

Vegetation maps originally developed and reported by Ostler et. al. (2000) were based on ELUs that delineated geological land forms which correlated well with different soil types (Peterson, 1981 ) and vegetation. Boundaries of ELUs were initially drawn by hand on clear plastic overlays placed over aerial photographs using standard photo interpretation techniques such as differences in color, texture, and slope position. The photobases used were those individual maps published in the NTS Site Grid Map (DOE/NV, Undated). These photo sheets and overlays were then taken into the field and polygon boundaries verified. If the vegetation within these polygons was not homogeneous, then the polygon was subdivided and the new subpolygon area(s) were further characterized by sampling of the vegetation. The ELU polygons were then combined into a single GIS coverage (i.e., shapefile) that could be projected over the orthophoto satellite images to create habitat maps. The polygons were cast on the UTM projection using North American Datum of 1927 (NAD27). This projection corresponds to that of all topographic quadrangle maps produced by the U.S. Geological Survey (USGS) in the 1970s and 1980s.

Because the orthophoto images were originally compiled from several satellite scenes (up to eight scenes in the case of SPOT; four multispectral scenes and four panchromatic scenes), with spatial resolution ranging from 10 to $30 \mathrm{~m}$, the synchronization of the polygons with the underlying imagery did not always register well (Figure 4, upper half of image). The projected polygon details where often shifted up to $100 \mathrm{~m}$ from the underlying image details due to small errors in mosaicing, digitizing, and projecting or converting coordinate systems of the polygons and image pixels. With the acquisition of the new more accurate orthophoto image, came the ability to display landscape details in greater detail $(0.5$ to $1.0 \mathrm{~m}$ resolution). Therefore, it was desirable to adjust the ELU polygons to overlay the new imagery and hence, improve mapping accuracy and GIS analyses (e.g., spatial analyses measuring correlations of vegetation and elevation, slope, and aspect).

Using the new orthophotos as a base, the older polygon shapefile was edited and converted to the UTM projection using NAD83, the projection most commonly used since the 1990s. The resulting shapefile and projection file ensure that the registration of the polygon coverage and the orthophotos is as accurate as possible (Figure 4, lower half of image).

\subsection{Recalculation of Spatial Coordinates for ELUs}

The location of sampling transects within ELUs was documented using two field methods. The first was to record in the field the spatial coordinates of each transect using a hand-held Global Positioning System (GPS) instrument that estimated, from multiple satellite signals, the UTM projection using NAD27. This projection was used because it roughly corresponded with published USGS topographic quadrangle maps. Because no GPS base station was available and the satellite signals were frequently scrambled daily or offset for military reasons, the accuracy of the GPS coordinates was estimated to be between 100 and $300 \mathrm{~m}$. In some areas of the NTS, satellite signals were blocked by terrain and transect coordinates could not be taken. 


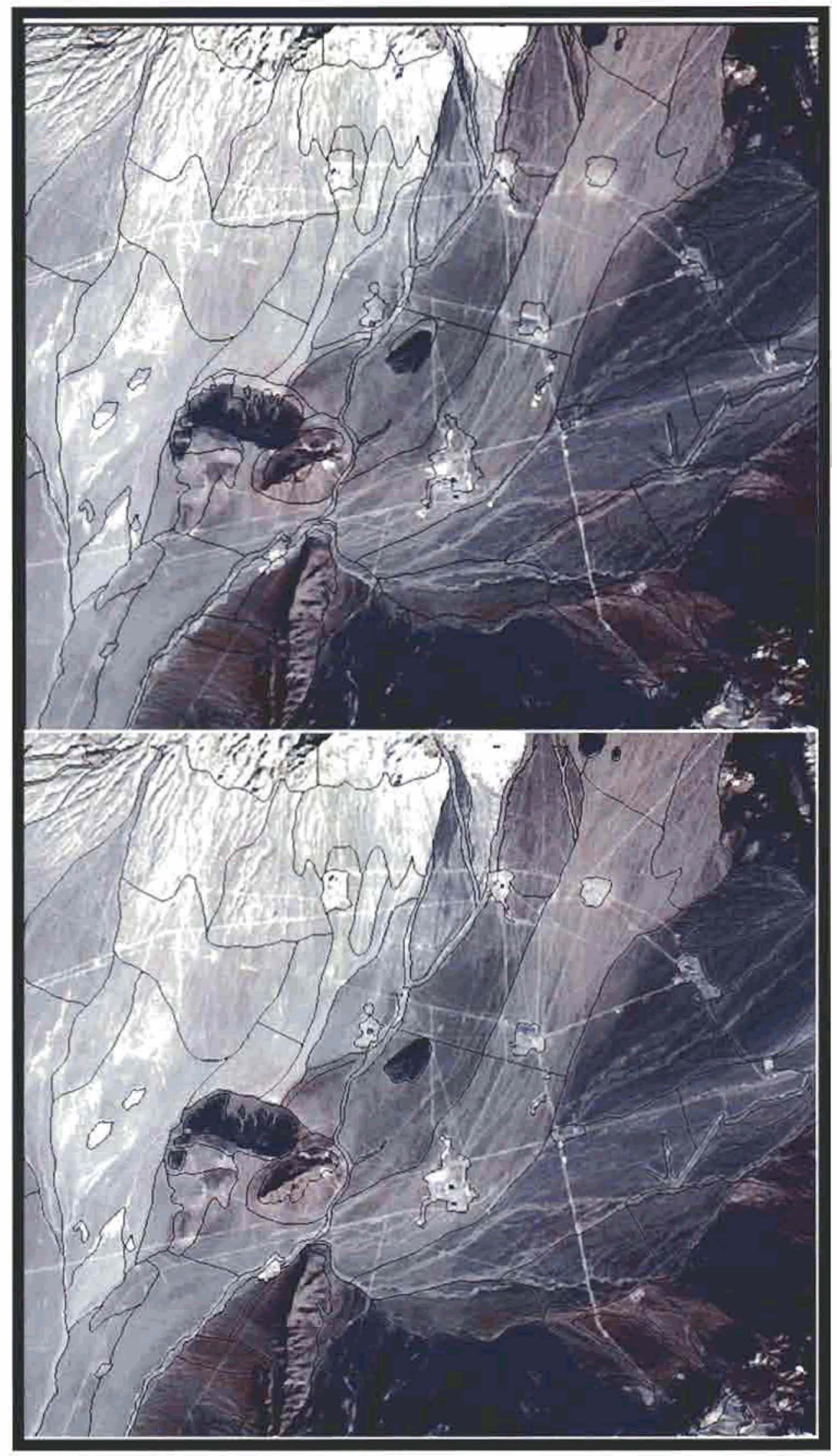

Figure 4. Example of inaccurate registration of ELU polygons with orthophotos in Jackass Flats (upper photo) and accurate registration after spatial adjustments were made (lower photo). 
The second field method consisted of marking the approximate location of the center of the transect on an aerial photograph. This location was frequently easy to locate because of the proximity of the transect to roads, washes, and other distinct landmarks that were readily apparent in the aerial photograph and in the field. Greater confidence was placed by the biologist in the latter method.

The acquisition of new orthophoto digital images this year made it desirable and possible to recalculate more accurate transect locations (i.e., spatial coordinates), based on the location of transects marked on the images while in the field. To do this, the field-acquired GPS coordinates of sample transects were projected on the new 1998 orthophoto images. The location of these projected coordinates were then compared with the locations of sample transect mid-points that had been drawn in the field on the original 1994 aerial photographs. Transect mid-points that were out of place on the orthophotos were repositioned into a correct location when viewed on the orthophoto images. Once all of the locations were compared and corrected, a new shapefile was created and converted to the UTM projection using NAD83. Figure 5 shows the projection of the old sample transect locations and the new, more accurate sample transect locations.

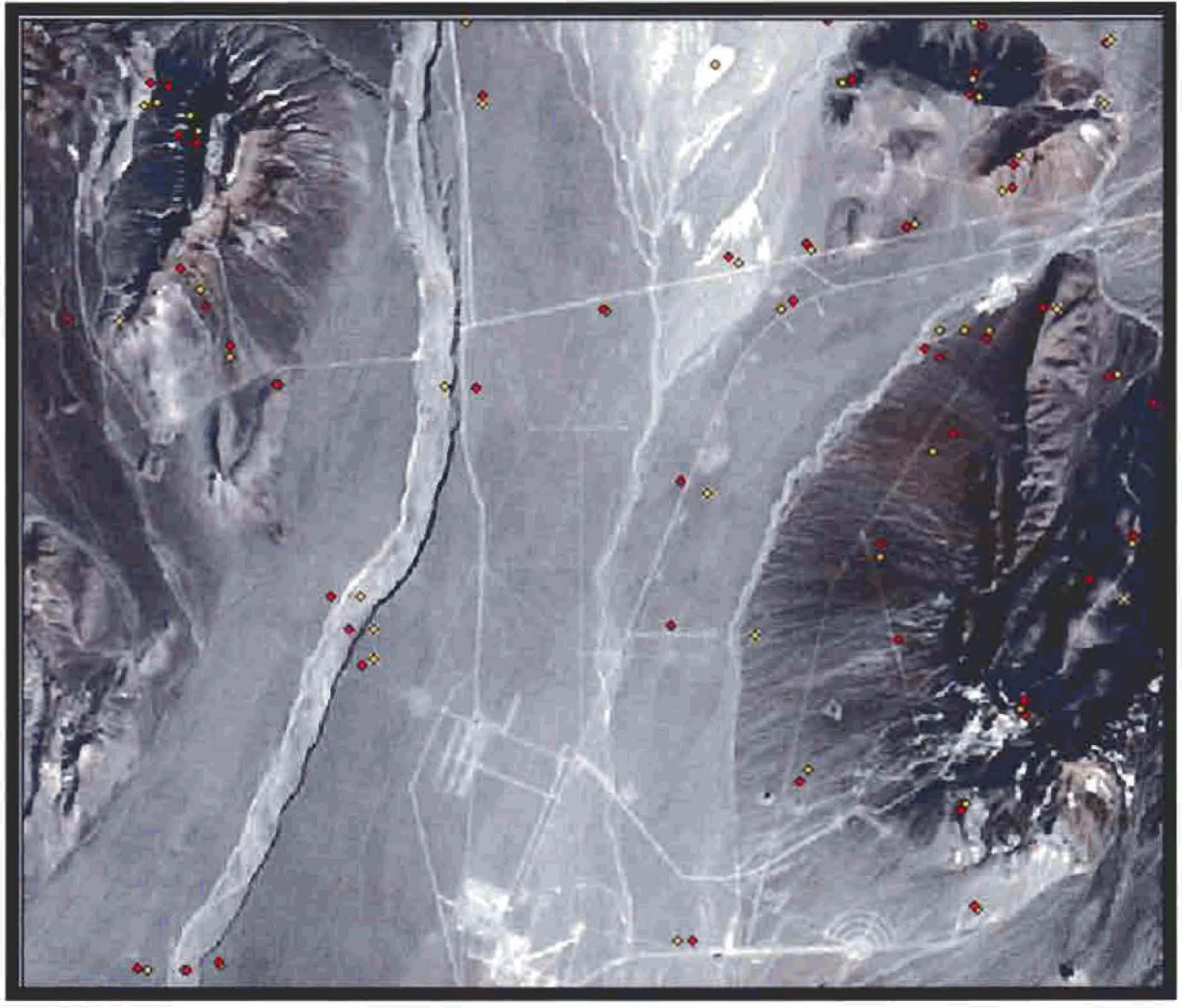

Figure 5. Example of old inaccurate locations of vegetation sampling transects in Jackass Flats (yellow) and their new accurate locations after corrections were made (red). 


\subsection{Resampling of ELUs}

ELUs that were sampled in 1996 lacked information about shrub canopy cover. Because 1996 was a drought year, few annual plant species were in bloom. Data collected after 1996 documented shrub canopy cover and had better representation of annual plant species. Photographs taken during 1996 were also substandard. They were made from transparency slides and the color quality of the slide film shifted dramatically through the season and during the five years since they were taken. Beginning in 1999, selected ELUs have been revisited as the opportunity presents itself, often during the conduct of other EMAC field activities, to obtain better photographs and vegetation data. During 2003, 280 ELUs were revisited to collect additional information and photographs. The new data and photographs were added or linked to the existing Ecological Geographic Information System (EGIS) database.

\subsection{Enhancement of ELU Photographs}

Original photographs taken during the sampling of vegetation to document site conditions at ELUs vary in quality. The first images were scanned from 35 millimeter $(\mathrm{mm})$ slides at rather low resolutions ( 300 kilobyte per image). The scanning resolution was low compared with resolutions achievable today (1-3 megabytes per image). The camera lens quality often contributed to vignetting with dark corners and a light center to the image, and the contrast, brightness, and color balance of the original photos were sometimes substandard. During 2003, many of the original photo quality problems were corrected using the photo-editing software

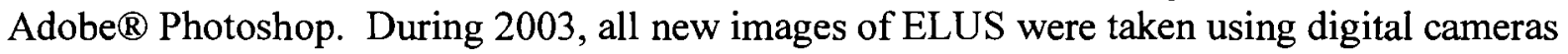
with high resolution images. Over 5,565 original and new images were edited to improve image quality.

Image file names were originally maintained to indicate the frame and roll number of the image. These names were altered in 2003 to reflect the ELU number, year, vegetation type, and image number at that site. This systematic renaming of images permits sorting of the files by year, vegetation type, or ELU and enables the printing of like categories of images. These images have been archived on DVD ROMs and linked to EGIS for easy retrieval.

\subsection{Development of NTS Fauna Databases}

Separate Microsoft $($ Access databases were developed for four groups of animals on the NTS: 1) invertebrates, 2) reptiles, 3) birds, and 4) mammals. Each database is comprised of five or more tables. Those tables that are common to each group's database include:

- Metadata Table - contains information about the database and is used to document changes to the database.

- Abundance - Alliance Table - contains a ranking of the abundance of the animal within each of the major NTS vegetation alliances.

- Phylogeny Table - contains all information describing the phylogeny of an animal.

- Species Summary Table - contains information on the animal's life history characteristics (e.g., foraging guilds, periods of activity).

- Observation Table - contains information that documents a sighting of an animal or its sign on the NTS. 
- Picklist Tables - contain selection lists for pull-down menus within other tables for standardization of spellings and data entry choices. Examples include the names of vegetation alliances, specimen locations, and techniques for collecting GPS coordinates.

All database tables were standardized for shared field names, data types, field lengths, date display preferences, and descriptions of the field with selected examples. They were also standardized whenever possible for assigned captions, validation rules, and default values of data fields. The standardization of formats provides consistency between databases and the ability to properly printout metadata that describes the database contents and structure in detail. Examples of the structure of tables within the mammals database are shown in Figure 6. During 2003, the phylogeny tables were completed for all four animal group types. The other tables will be completed during 2004 as funding permits.

A fifth database, the Photo Status Database, was developed to document the sources and use requirements for copyrighted digital images of animals (Figure 7). The database will document that permission to use an image is granted. Examples of digital images from the three groups of animal types are shown in Figure 8. During 2003, images were secured for all reptiles and for most of the birds and mammals of the NTS. Because of the diversity and number of invertebrates present on the NTS and lack of commercial images, no images of invertebrates will be collected as part of the faunal study.

Work continued this year on entering location coordinates of historical animal sightings and specimen collection sites from the NTS into the EGIS faunal databases. BN biologists continued to review published vertebrate and invertebrate inventories and research performed on the NTS to identify geographical information. Over 1,000 small mammal historical species' presence records from Janice Beatley plots established from 1964-1968 have been obtained and entered into the mammal database. Wildlife observations made by $\mathrm{BN}$ biologists or reported to Ecological Services by NTS workers this year were entered into the EGIS faunal databases. The completion of data entry of historical NTS wildlife data and the start of production of faunal distribution maps will occur next year as funding permits.

\subsection{Coordination With Ecosystem Management Agencies/Scientists}

BN biologists continued to assist the USGS Biological Services with the exchange of information about historical habitat plots established by Janice Beatley on the NTS in the 1970s. BN biologists also accompanied scientists from Neptune and Company, Inc., of Los Alamos, New Mexico to their NTS sampling locations and provided procedural oversight of their field research. Their research involves characterizing the potential biointrusion of ants and termites into buried waste. A BN biologist also assisted U.S. Forest Service personnel in the establishment of a permanent plot on Pahute Mesa. This plot is part of a western United States study evaluating forest structure and health. 


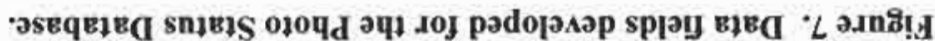

\begin{tabular}{|c|c|c|c|c|}
\hline \multirow[t]{17}{*}{$\sqrt{10}$} & & & & \\
\hline & 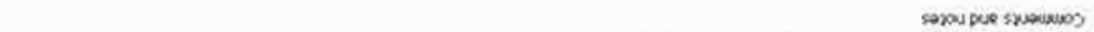 & owew & sexon & 4 \\
\hline & 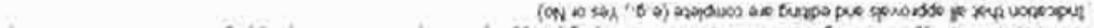 & oavisen & sagapdins & \\
\hline & 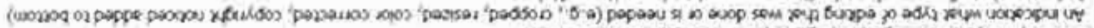 & $2 \times 01$ & boums & \\
\hline & 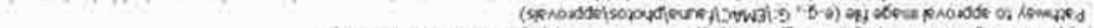 & & 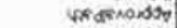 & \\
\hline & 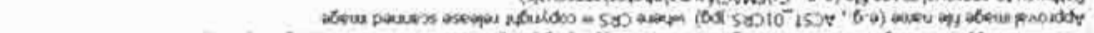 & $\operatorname{pos}_{1}$ & ansinowsty & \\
\hline & 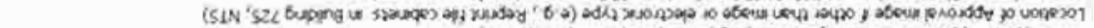 & 200 & sonesardity & \\
\hline & 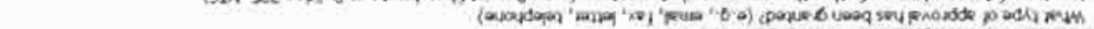 & $\operatorname{lot}_{i}$ & 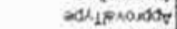 & \\
\hline & 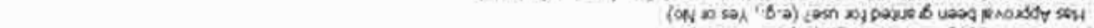 & trot & Henovope & \\
\hline & 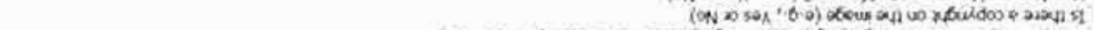 & ral & ingandos & \\
\hline & 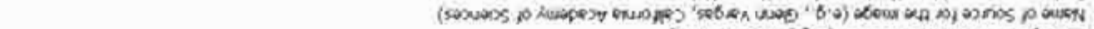 & $\operatorname{xos}_{i}$ & amos & \\
\hline & 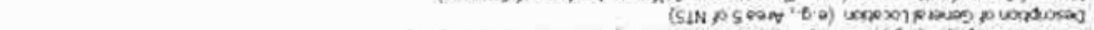 & too & vecoserol & \\
\hline & 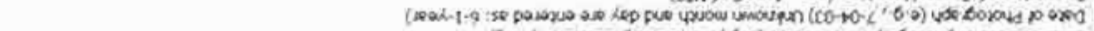 & Tanjexe & seg & \\
\hline & 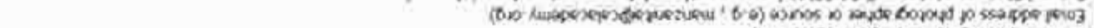 & 201 & mase & \\
\hline & 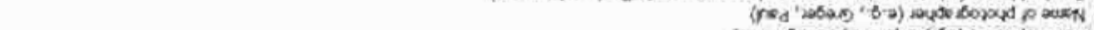 & Di & 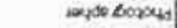 & \\
\hline & 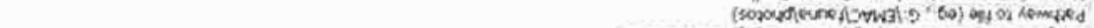 & $m_{1}$ & $4 \times d$ & \\
\hline & 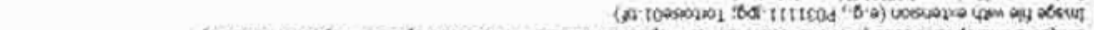 & rail & का & \\
\hline ᄃ & 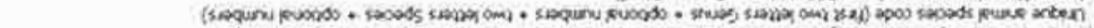 & noi & scojoss & \\
\hline 5 & 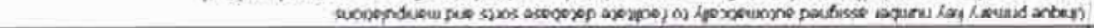 & acuravorivy & d] & 3. \\
\hline 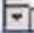 & 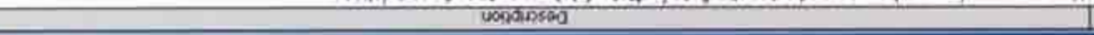 & अवरा जुल्व & KOWN PRP & \\
\hline \multicolumn{3}{|c|}{$\sqrt{\bar{x}}|\overline{0}|^{2}$} & Iger : smpens ojoyd & \\
\hline
\end{tabular}

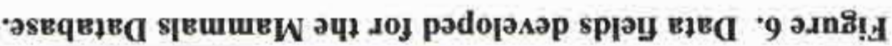

\begin{tabular}{|c|c|c|c|c|}
\hline & 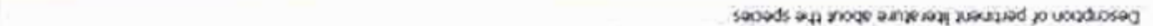 & & & \\
\hline & 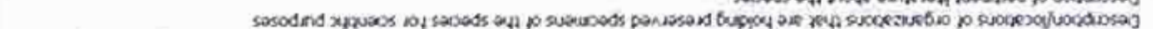 & ondent & 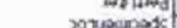 & \\
\hline & 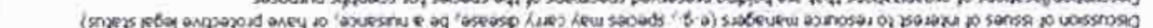 & & soluowiosis & \\
\hline & 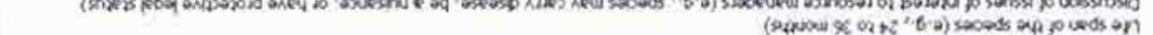 & waw & 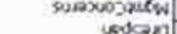 & \\
\hline & 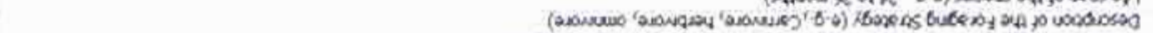 & $x \times 1$ & xescolent & \\
\hline & 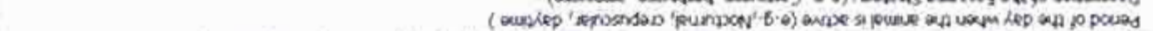 & $x_{1}$ & pouagangont & \\
\hline & 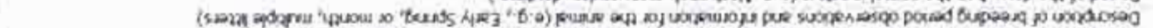 & anew & pouabunasia & \\
\hline & 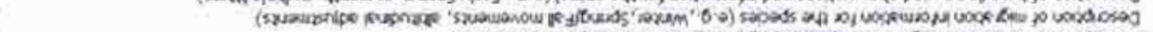 & mol & voce Lw & \\
\hline & 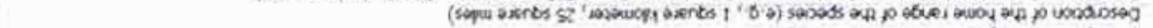 & 201 & obe youph & \\
\hline & 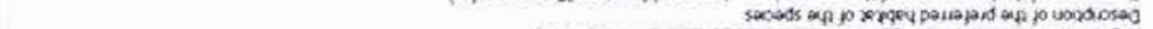 & outw & 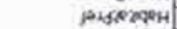 & \\
\hline & 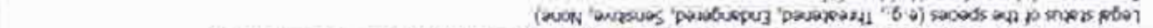 & mol & incerseler & \\
\hline & 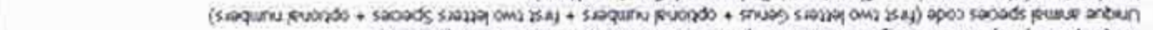 & $\operatorname{mot}$ & $200>0 \mathrm{~d} / 5$ & \\
\hline & 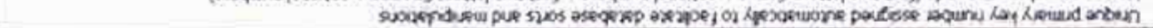 & Dainvorit & & \\
\hline$\nabla$ & 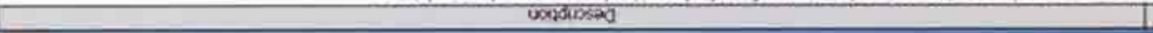 & क्वराजल & 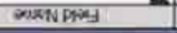 & \\
\hline $\mid \vec{x}$ & $\left.\bar{\square}\right|^{-2}$ & & Mewuins ranads & \\
\hline & 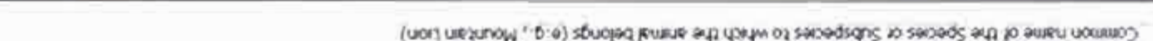 & $\mathrm{x} \times \mathrm{s}$ & wuondset & \\
\hline & 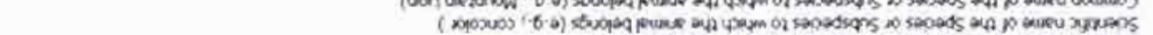 & 201 & osdoransodst & \\
\hline & 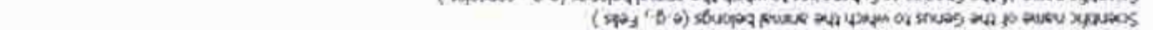 & $x_{2}$ & ossmest & \\
\hline & 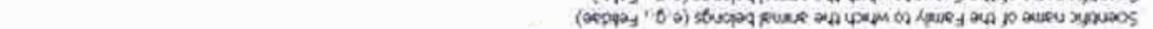 & vai & ospuret & \\
\hline & 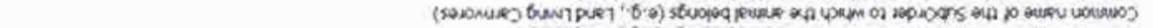 & $2 \times 1$ & 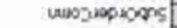 & \\
\hline & 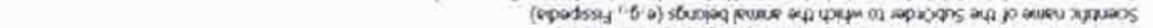 & 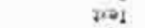 & osmopert & \\
\hline & 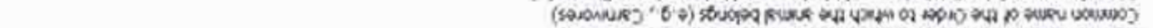 & $x$ & wojespe & \\
\hline & 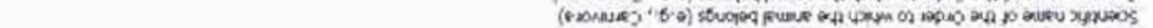 & $x \rightarrow 1$ & 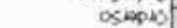 & \\
\hline & 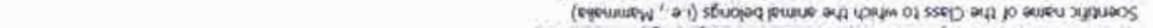 & mat & is sese & \\
\hline & 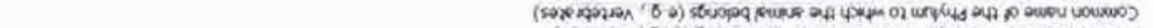 & WaI & 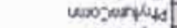 & \\
\hline & 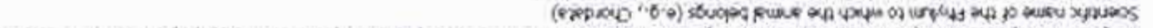 & $x \in 1$ & issurvitat at a & \\
\hline L- & 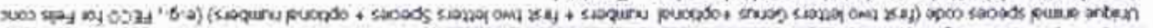 & $2 \times a 1$ & apojosds & \\
\hline & 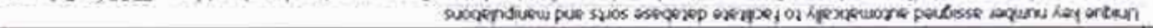 & equarnomy & al & \\
\hline -1 & Wordos 90 & ब्वरण $\times 0$ & क्जातनस & \\
\hline $\mid \bar{x}$ & El= & (2) & etunuewhuabojkyd & \\
\hline$\sqrt{4}$ & 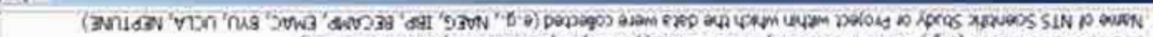 & $2 \times 91$ & Rrussin & \\
\hline & 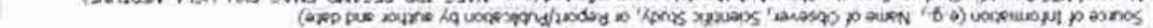 & Hial & mnosolul & \\
\hline & 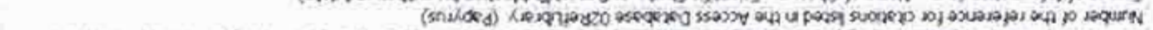 & equirei & urnsonilited & \\
\hline & 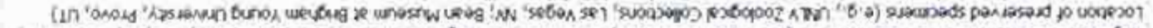 & 201 & sonjourods & \\
\hline & 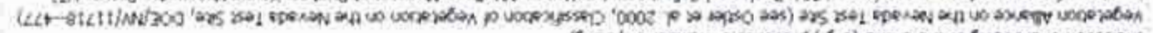 & $\operatorname{rat}$ & 20ur & \\
\hline & 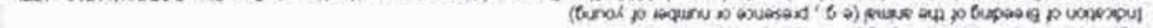 & $m_{1}$ & вupaen 8 & \\
\hline & 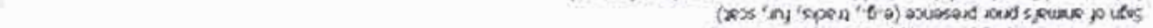 & $2 \times 1$ & cons & \\
\hline & 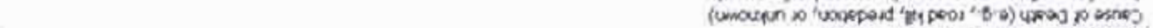 & $m i$ & astrounew & \\
\hline & 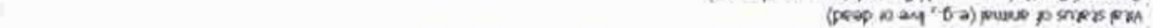 & $\lim _{1}$ & pergavi & \\
\hline & 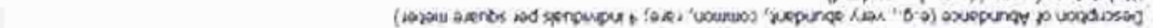 & $\times \infty_{1}$ & exuspungy & \\
\hline & 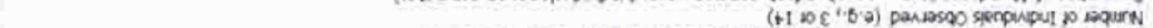 & raquiren & DNPUIuren & \\
\hline & 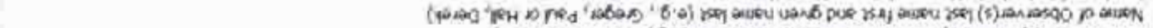 & $\operatorname{mal}$ & andasso & \\
\hline & 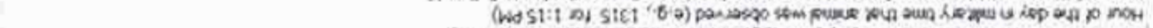 & bogiren & snowpenel & \\
\hline & 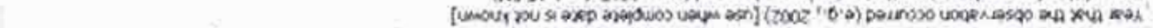 & iequan & Eai & \\
\hline & 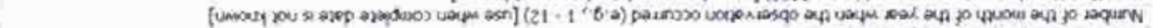 & Iequirn & yoow & \\
\hline & 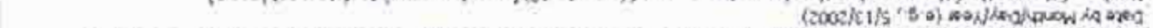 & miliaxig & sateg & \\
\hline & 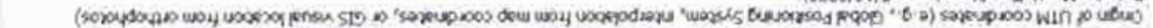 & $\ln 21$ & chow!n & \\
\hline & 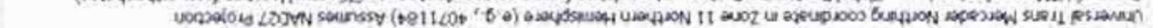 & isquines & Nwin & \\
\hline & 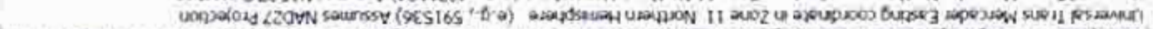 & agurw & 3win & \\
\hline & 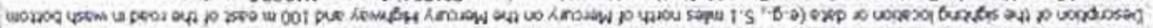 & ousw & $x \rightarrow 0 \times 01$ & \\
\hline [ & 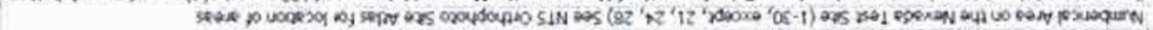 & iscoures & sansis & \\
\hline & 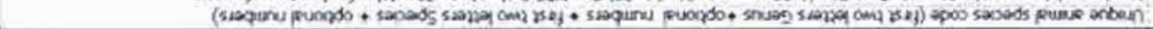 & $x+1$ & apojdds & \\
\hline - & 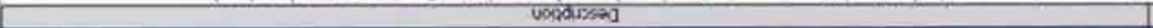 & उस्बलू & 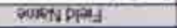 & \\
\hline & 问 & & aqqe1 = spoutuen & \\
\hline
\end{tabular}




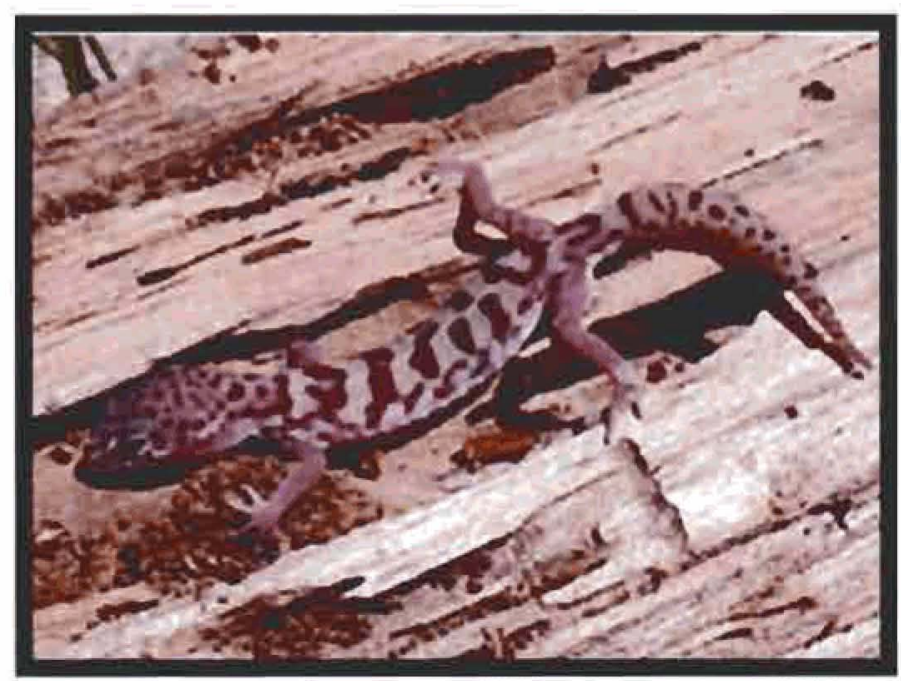

Desert banded gecko, photo by William Flaxington, (C) 2003

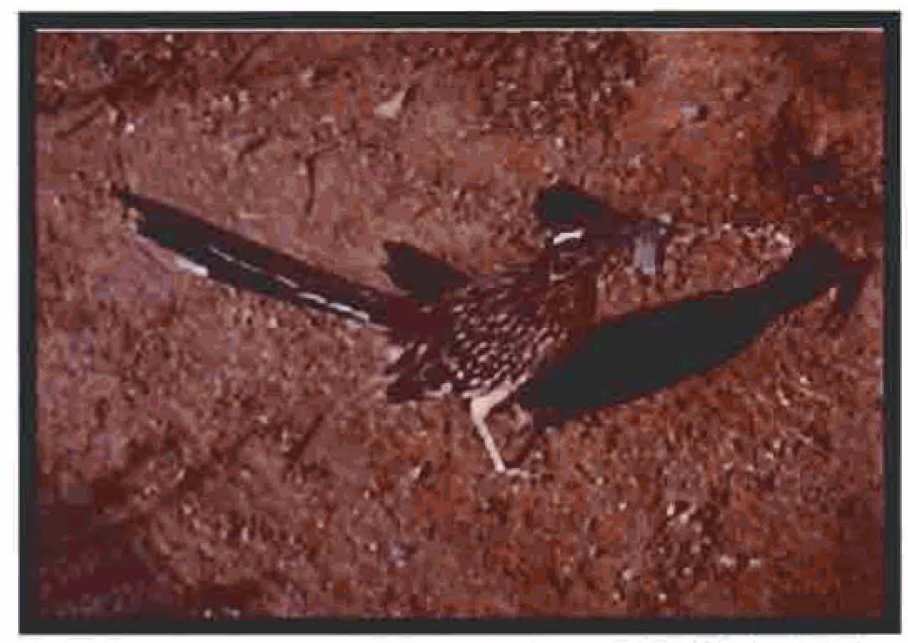

Greater roadrunner, photo by Jules Straus, 1999 California Academy of Sciences

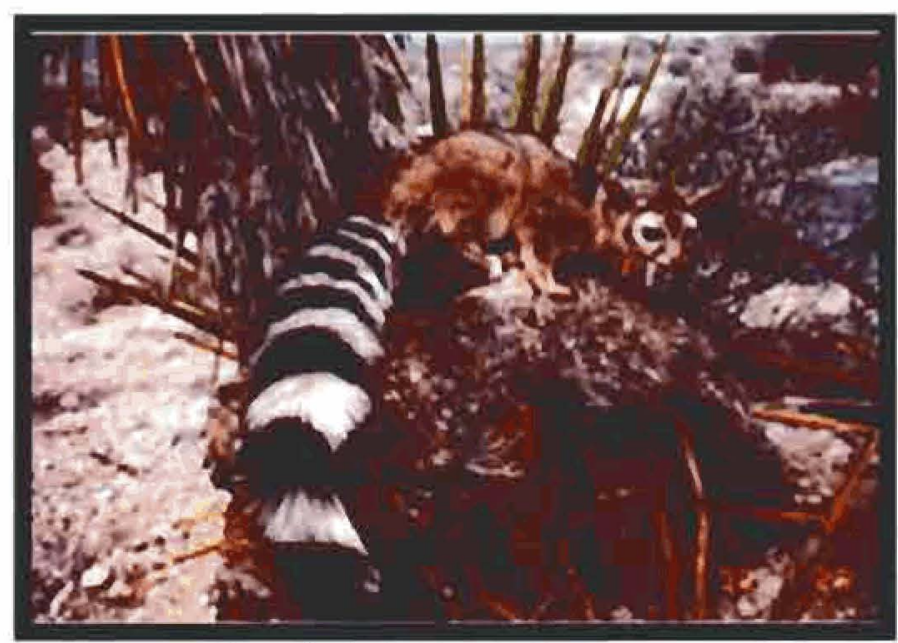

Ringtailed cat, photo by Paul Greger

Figure 8. Examples of digital image files of NTS wildlife collectedfor inclusion in faunal databases. 


\subsection{SENSITIVE SPECIES AND HABITAT MONITORING}

There are 22 plants and 34 animals which occur on the NTS that are considered sensitive because they are either: (a) listed as threatened or endangered under the ESA, (b) current candidates for listing, (c) species of concern to FWS or state agencies, or (d) state-managed species (Table 1). The desert tortoise is the only threatened or endangered species which could be significantly impacted by NNSA/NSO activities. EMAC tasks related to the desert tortoise are addressed in Section 3.0 of this report. As with the desert tortoise, the goal of species and habitat monitoring is to ensure the continued presence of all sensitive plants and animals on the NTS by protecting them from significant impacts due to NNSA/NSO actions. A secondary goal is to gather sufficient information on these species' distribution and abundance on the NTS to determine if further protection/management under state or federal law is necessary. Information on species' distribution and abundance is obtained from field surveys. Frequent monitoring of these species provides information on their current status and identifies actions, if any, that might be necessary to protect them. Natural and man-made water sources on the NTS are rare and unique habitats which are also routinely monitored to assess their use by wildlife and their status.

\subsection{Sensitive Plant Species}

In 1998, NNSA/NSO prepared a Resource Management Plan (RMP) (DOE/NV, 1998) with the objective to protect and conserve sensitive species found on the NTS and to minimize cumulative impacts to those species as a result of NNSA/NSO activities. Pursuant to that document, BN published and distributed an Adaptive Management Plan for Sensitive Plant Species on the Nevada Test Site (BN, 2001). The plan presents the procedures designed to ensure that the RMP goals are met by identifying parameters to be measured during long-term monitoring and outlining management actions that may be taken if significant threats to sensitive species are detected.

\subsubsection{Review of Sensitive Plant Species of the NTS}

The management plan calls for an annual review of those plant species found on the NTS which may require protection because of such factors as rarity, susceptibility to disturbance, or importance. Other agencies are also consulted during this review to determine which species should be protected and monitored. The Nevada Department of Conservation and Natural Resources of the Nevada Natural Heritage Program (NNHP) maintains a detailed list of rare vascular and non-vascular plants. This detailed list includes plants protected by federal agencies, the Division of Forestry of the State of Nevada, and the Nevada Native Plant society. Any species included in their list and known or suspected to occur on the NTS are included in the list of NTS sensitive plant species (Table 1).

The list of sensitive plant species of the NTS was reviewed this year, and no species were added or removed. Of the 17 vascular and 5 non-vascular plants on the list, none are listed by the FWS as endangered or threatened, 1 is listed as a Nevada Threatened species, 11 are considered Species of Concern by the FWS, and all are included on NNHP's plant watch list (Table 1). 


\subsubsection{Long-term Monitoring}

The goal of long-term monitoring of sensitive plant species, as described in the management plan, is to acquire an accurate delineation of their populations on the NTS and to periodically assess their status for conservation and management purposes. Each sensitive plant species is categorized according to its need for active monitoring. They are labeled either Active, Inactive, or Evaluate (A, IA, or E; see Table 1). Species classified as Active are monitored and include those known to occur on the NTS, are on the FWS or NNHP list of sensitive plant species, and have limited distribution either on the NTS or over their entire range. Species classified as Inactive are not included in the long-term monitoring plan and include species that are known to occur on the NTS but for which there is sufficient information to suggest that their distribution is widespread enough on the NTS, in Nevada, or over their entire population range, that protective actions are not needed. Their presence at proposed project sites is still documented during biological surveys. Species classified as Evaluate are those for which there is insufficient information to determine if they occur on the NTS, or if they do occur, whether their distribution or abundance warrants protection and monitoring. The list of sensitive plant species on the NTS (Table 1) includes ten species to be actively monitored, five to be evaluated, and seven that will not be monitored. Six of the ten species that will be monitored are annual forbs, three are perennial forbs, and one is a perennial shrub. All five of the species to be evaluated are bryophytes (mosses).

Field monitoring to assess population status is to be conducted for each Active species at least once every five years. A minimum of two species are selected each year and a representative number of populations are monitored. For most of the sensitive species, population locations and habitat descriptions have been recorded during previous field studies (Blomquist et al. 1992, Blomquist et al. 1995). Other data will be collected during field monitoring to ascertain the current status of the species and may include density of plants, evidence of herbivory, disease, or evidence of direct or indirect disturbance to its habitat.

Two species were selected to be monitored this year: Phacelia beatleyae (Beatley's phacelia), an annual forb, and Astragalus funereus (black woollypod), a perennial forb. Growing conditions this fiscal year were better than last year but annual precipitation was still below normal. Early spring rains were abundant on some parts of the NTS yet absent in others. In those areas receiving rain there was good growth of annual forbs and grasses. However the perennial forbs and shrubs, which are more dependent on fall and winter rains, did not respond as favorably to the spring rains. No evaluations of sensitive bryophytes were conducted this year.

\subsubsection{Phacelia beatleyae}

$P$. beatleyae is a small annual herb $2-4$ inches high with a reddish stem and slightly fleshy, dark green, and entire leaves (Figure 9). It typically flowers and sets seed in late spring. The best time for surveys is in May and June. Typically, populations are found from 4,000 to 5,100 ft elevations in loose, light-colored volcanic tuff on relatively steep slopes (Figure 10). There are three major concentrations of $P$. beatleyae on the NTS (Figure 11). One is on the western slope of Skull Mountain in Area 25. Another is on the slopes of French Peak, and the third area is on the slopes of the Halfpint Range. The goal this fiscal year was to collect density estimates of $P$. beatleyae and to note any conditions that may be impacting the plants (e.g., herbivory, disease, etc.). 


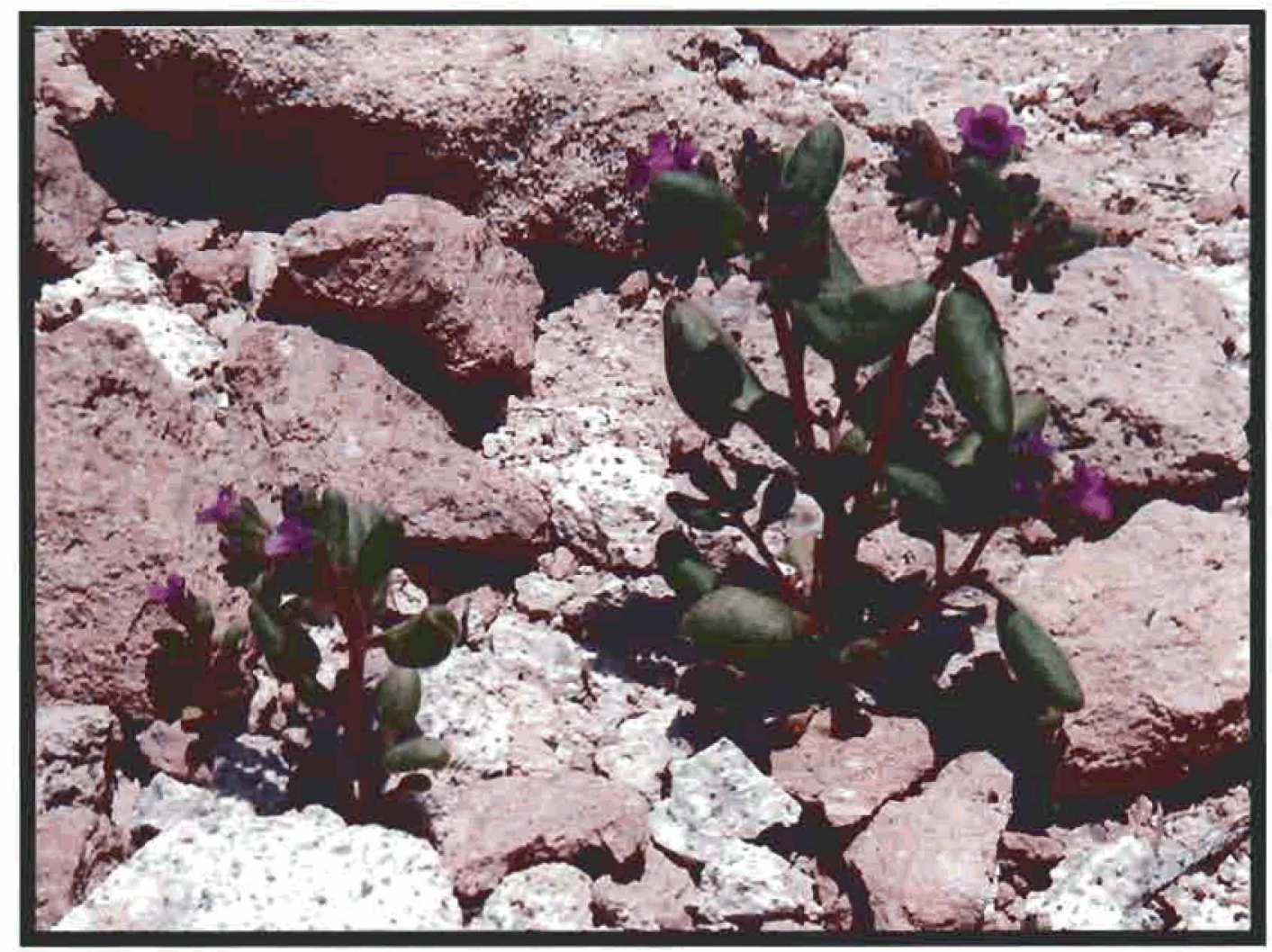

Figure 9. Phacelia beatleyae in flower east of Orange Blossom Road (photo by W. Kent Ostler, May 2003)

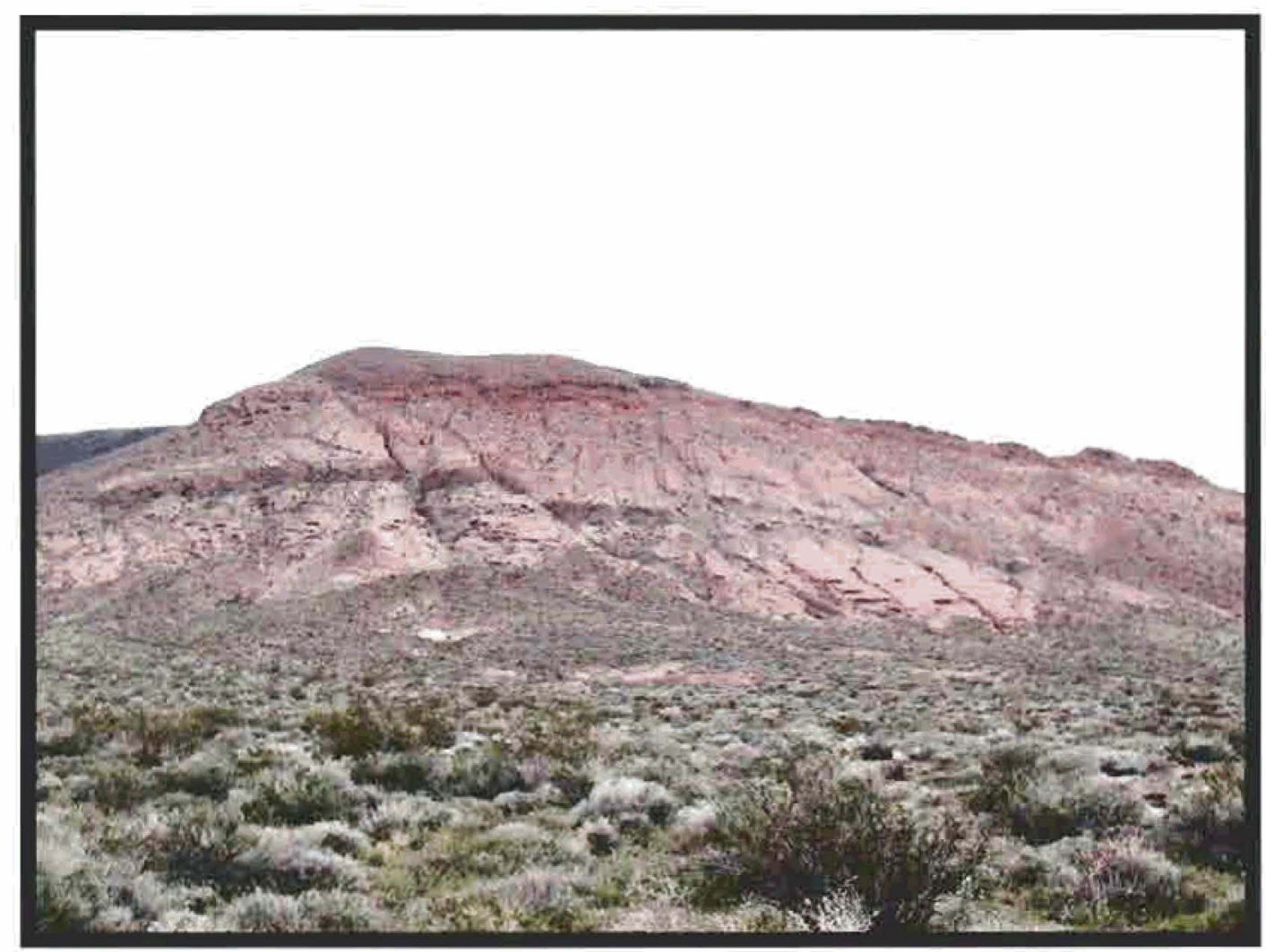

Figure 10. Typical habitat for Phacelia beatleyae on western slope of Skull Mountain in voleanic tuff on mid to upper slopes (photo by Dave Anderson, May 2003) 


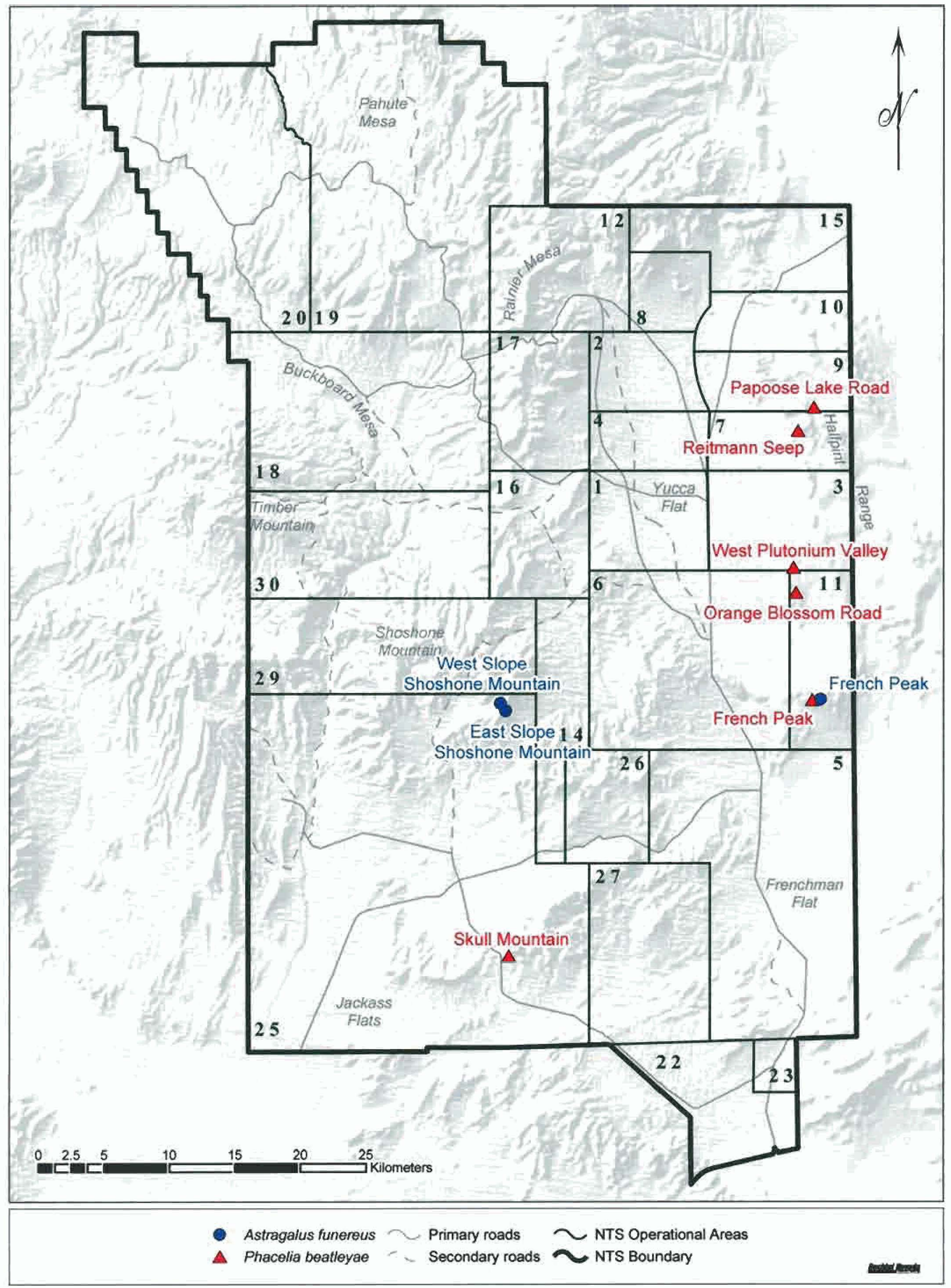

Figure 11. Sensitive plant populations monitored on the NTS during FY 2003 
During preliminary surveys at different locations, numerous individuals of $P$. beatleyae were observed. Based on these preliminary surveys, six areas were selected to be evaluated in 2003. Four were along the slopes of the Halfpint Range. The northern-most site is south of Papoose Lake Road in low foothills on the eastern slopes of Slanted Buttes. A fourth site is further north on the western slopes of Slanted Buttes and north of Reitmann Seep. Two of several reported locations were found on the western slopes of the Halfpint Range and are referred to as the West Plutonium Valley and Orange Blossom Road sites (Figure 11, Table 6). The other two sites are along the upper slopes of French Peak and the western slope of Skull Mountain.

Field sampling involved walking meandering transects through typical $P$. beatleyae habitat. No permanent transects were established, as is done for perennial species that are monitored, because of the more disjointed distribution of annual plants. Habitat location coordinates were recorded and the numbers of plants found in each location were estimated. Habitat characteristics were recorded as well as potential threats to the species, if any were observed. Approximately six person days were spent conducting field surveys for $P$. beatleyae.

Although numerous individuals were found at each of the six sites monitored, numbers were lower than had been reported from previous years (Table 6). For example, at the population near Reitmann Seep, over 400 individuals were found this year. In comparison, in 1992 over 23,000 were estimated to occur at this site. Yet, at another site east of Orange Blossom road and west of Plutonium Valley, over 400 plants were found this year which is only slightly lower than the 500 plants found there in 1993. At the Papoose Lake Road site, about 250 individuals were found in 1992, but this year none were found. It was obvious during the survey that this northern area had not received the moisture that the other sites had received. Soils were dry and not only was there a scaricity of annuals, but the shrubs common to the area showed no signs of growth this year. Numbers of $P$. beatleyae found this year per site seem to be commensurate with the amount of precipitation each site received. This species will continue to be monitored over time and information obtained from this year's survey will be shared and compared with the work of other agencies and groups. 
Table 6. Characteristics of Phacelia beatleyae habitat on the NTS.

\begin{tabular}{|c|c|c|c|c|c|c|}
\hline \multirow[b]{2}{*}{ Habitat Feature } & \multicolumn{6}{|c|}{ Plant Population Location } \\
\hline & French Peak & $\begin{array}{c}\text { Papoose Lake } \\
\text { Road }\end{array}$ & Reitmann Seep & $\begin{array}{l}\text { Orange Blossom } \\
\text { Road }\end{array}$ & $\begin{array}{l}\text { West Plutonium } \\
\text { Valley }\end{array}$ & Skull Mountain \\
\hline Elevation (ft) & $4,300-4,700$ & $5,200-5,500$ & $4,500-5,300$ & $4,100-4,200$ & $4,100-4,300$ & $4,000-4,650$ \\
\hline $\begin{array}{l}\text { Vegetation } \\
\text { Association ' }\end{array}$ & $\begin{array}{c}\text { Blackbrush-Nevada } \\
\text { Jointfir }\end{array}$ & $\begin{array}{c}\text { Blackbrush-Nevada } \\
\text { Jointfir }\end{array}$ & $\begin{array}{c}\text { Blackbrush-Nevada } \\
\text { Jointfir }\end{array}$ & $\begin{array}{l}\text { Shadscale-White } \\
\text { bursage }\end{array}$ & $\begin{array}{l}\text { Shadscale-White } \\
\text { bursage }\end{array}$ & $\begin{array}{c}\text { Shadscale-White } \\
\text { bursage }\end{array}$ \\
\hline Soils & $\begin{array}{l}\text { whitish volcanic } \\
\text { tuff }\end{array}$ & $\begin{array}{l}\text { whitish volcanic } \\
\text { tuff }\end{array}$ & $\begin{array}{l}\text { reddish volcanic } \\
\text { tuff }\end{array}$ & $\begin{array}{l}\text { whitish volcanic } \\
\text { tuff }\end{array}$ & $\begin{array}{l}\text { whitish volcanic } \\
\text { tuff }\end{array}$ & $\begin{array}{l}\text { reddish volcanic } \\
\text { tuff }\end{array}$ \\
\hline Slope (\%) & $30-45$ & 35 & $20-45$ & $10-35$ & $10-35$ & $20-45$ \\
\hline \multicolumn{7}{|l|}{ Plant Abundance $^{2}$} \\
\hline 1991 & & & & & & $130+$ \\
\hline 1992 & $10,000+$ & $250+$ & $23,000+$ & & & \\
\hline 1993 & & & & $500+$ & $2,000+$ & \\
\hline 2003 & $800+$ & 0 & $400+$ & $400+$ & $130+$ & $530+$ \\
\hline
\end{tabular}

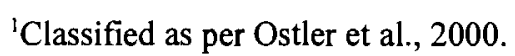

${ }^{2}$ Estimated during site visits. 


\subsubsection{Astragalus funereus}

A. funereus is a perennial forb which forms a mat with prostrate stems up to 4 inches in length (Figure 12). It flowers and sets seed in early spring to early summer. A. funereus is only known from a couple locations on the NTS. One is in the vicinity of French Peak in the Massachusetts Mountains of the Halfpint Range near the eastern border of the NTS. The other sighting of $A$. funereus is along the eastern and western slopes of the southern reaches of Shoshone Mountain. The preferred habitat of $A$. funereus is similar to that of $P$. beatleyae, which is a volcanic tuff on steep upper slopes (Figure 13). Elevation ranges from 4,000 to 5,000 feet near French Peak and from 5,600 to 6,400 feet on Shoshone Mountain.

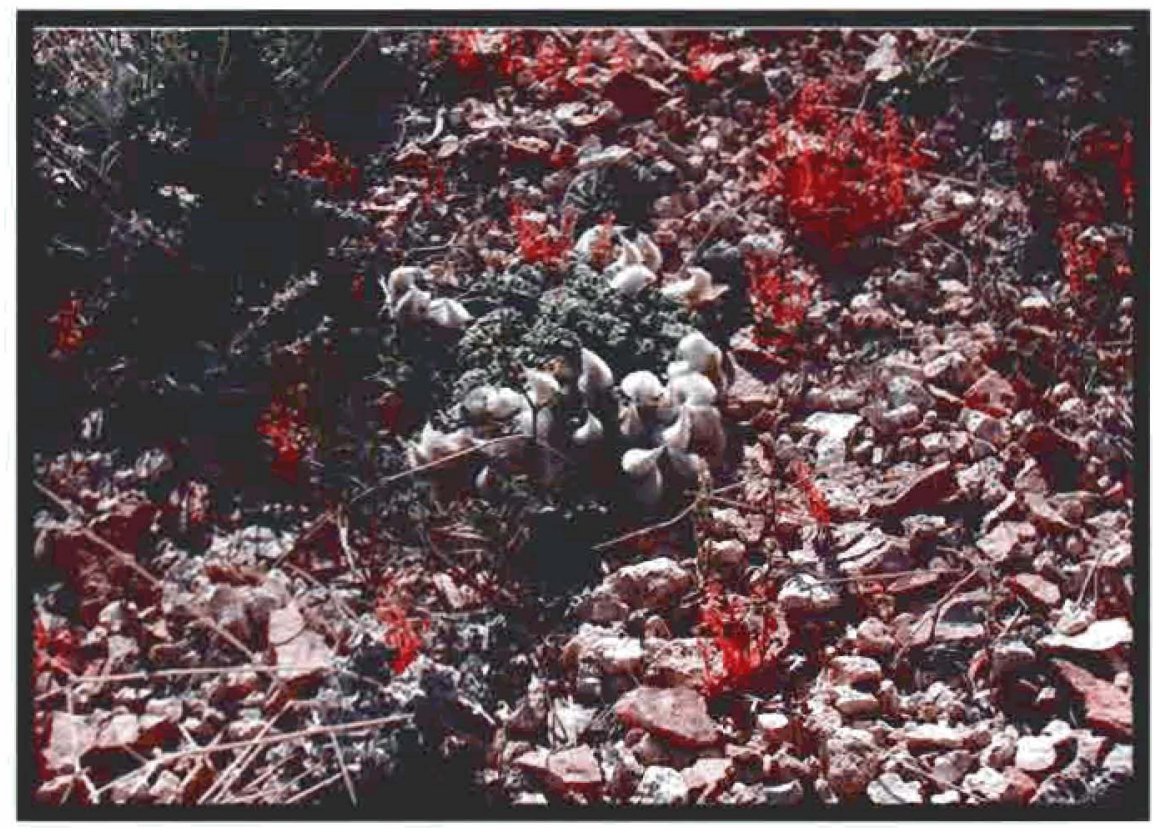

Figure 12. Astragalus funereus with seed pods found on east slope of Shoshone Mountain (photo by Dave Anderson, May 2003)

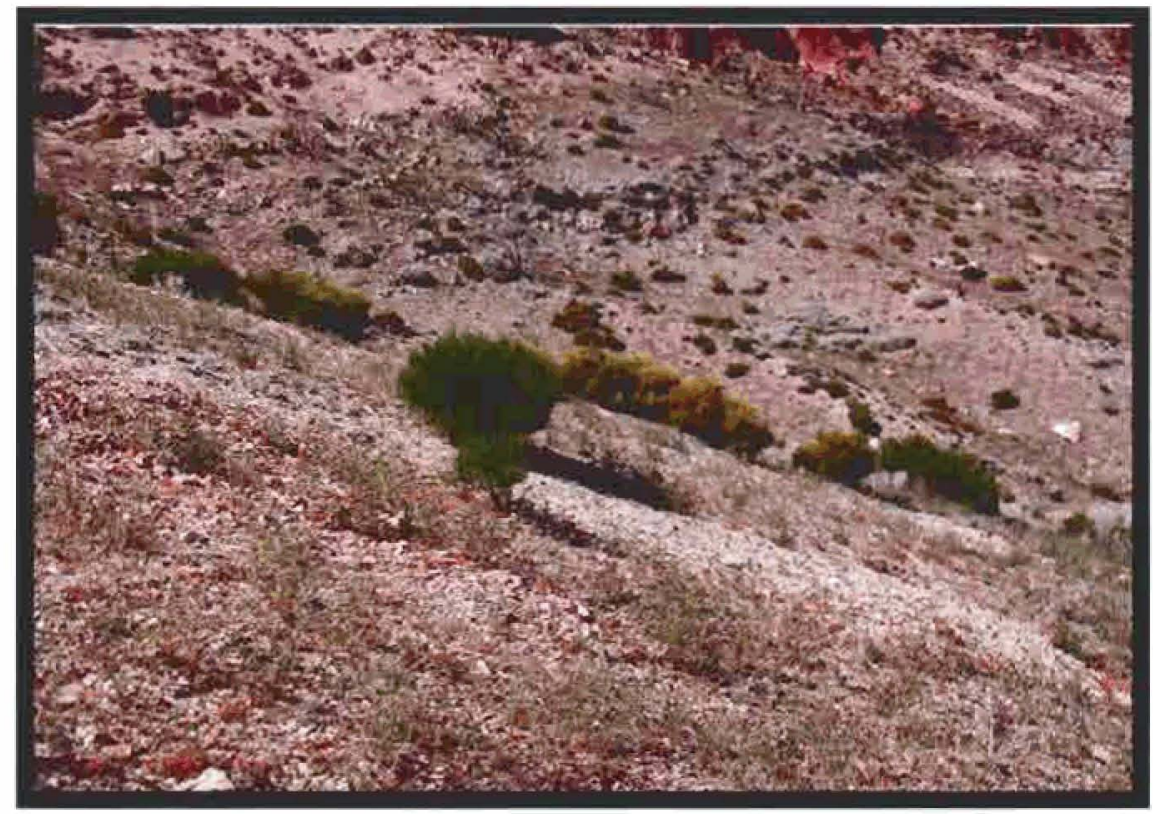

Figure 13. Typical habitat for Astragalus funereus on eastern slope of Shoshone Mountain (photo by Dave Anderson, May 2003) 
Approximately five person-days were spent in mid-May conducting field surveys for $A$. funereus at known population locations (Figure 11). Some habitat data were collected at the sites (Table 7) and added to the sensitive plant database. However, only two flowering plants and one seedling of $A$. funereus were found during the surveys. Two plants had flowered and set seed on the eastern slope of Shoshone Mountain (Figure 12). They were found near the upper slope in a grayish volcanic talus slope in association with Eriogonum microthecum spp. foliosum (Simpson's buckwheat), Atriplex canescens (fourwing saltbush) and Ephedra viridis (mormon tea). During surveys in the French Peak area, only one seedling was encountered and was tentatively identified as $A$. funereus.

The low abundance of $A$. funereus this year does not necessarily indicate a decline of this species on the NTS, but does indicate an effect of the continued drought in the southwest. The spring rains were not of the intensity and duration needed to restore soil moisture to levels needed for $A$. funereus growth and reproduction. There is no current need for corrective action. Climatic conditions should be monitored closely in the future and when conditions favoring $A$. funereus growth and reproduction occur, surveys should be conducted so an accurate assessment of the status of this species can be made. If at that point similar densities are found, consultation with state and federal agencies may be appropriate to determine the overall status of the species and then jointly develop appropriate corrective actions.

Table 7. Characteristics of Astragalus funereus habitat on the NTS

\begin{tabular}{|c|c|c|c|c|}
\hline \multirow{2}{*}{\multicolumn{2}{|c|}{ Habitat Feature }} & \multicolumn{3}{|c|}{ Plant Population Location } \\
\hline & & French Peak & $\begin{array}{l}\text { East Slope Shoshone } \\
\text { Mountain }\end{array}$ & $\begin{array}{c}\text { West Slope Shoshone } \\
\text { Mountain }\end{array}$ \\
\hline Elevation (ft) & & $4,000-5,000$ & $5,600-6,400$ & $5,700-6,300$ \\
\hline $\begin{array}{l}\text { Vegetation } \\
\text { Association }^{1}\end{array}$ & & $\begin{array}{l}\text { Blackbrush-Nevada } \\
\text { Jointfir }\end{array}$ & $\begin{array}{c}\text { Singleleaf Pine - Basin Big } \\
\text { Sagebrush }\end{array}$ & $\begin{array}{c}\text { Singleleaf Pine - Basin Big } \\
\text { Sagebrush }\end{array}$ \\
\hline Soils & & whitish volcanic tuff & whitish volcanic tuff & reddish volcanic tuff \\
\hline Slope (\%) & & $30-40$ & $20-45$ & $20-45$ \\
\hline \multicolumn{5}{|c|}{ Plant A bundance $^{2}$} \\
\hline & 1991 & 16 & 36 & $100-1,000$ \\
\hline & 1992 & & 127 & $23,000+$ \\
\hline & 1993 & $300+$ & & \\
\hline & 2003 & 1 & 2 & 0 \\
\hline
\end{tabular}

'Classified as per Ostler et al., 2000.

${ }^{2}$ Estimated during site visits. 


\subsubsection{Coordination With Natural Resource Agency Botanists}

On April 1, 2003, the NNHP held its annual meeting in Las Vegas, Nevada. Participants included state and federal agencies, academia, land resource managers, and private concerns. This meeting provides an opportunity for resource agencies to coordinate their efforts to protect rare plant species and make recommendations regarding species that may need or no longer need protection under state or federal laws and regulations. A representative from $\mathrm{BN}$ attended this year's meeting. No further action or change of status was proposed for any plant species that occurs on the NTS.

\subsection{Sensitive Animal Species}

Some of the federally protected animals and animal species of concern listed in Table 1 have been sighted on the NTS, however no site-wide surveys to determine their distribution or abundance have been conducted. They include the threatened bald eagle (Haliaeetus leucocephalus), the formerly endangered American peregrine falcon (Falco peregrinus anatum), the candidate mountain plover (Charadrius montanus), and three bird species of concern: the ferruginous hawk (Buteo regalis), western least bittern (Ixobrychus exillis hesperis), and whitefaced ibis (Plegadis chihi). All of these birds are uncommon transients to the NTS and are not expected to be impacted by NTS activities. Records of bird sightings that are made opportunistically by EMAC biologists and other NTS workers are maintained to provide some data on these species' occurrence on the NTS.

Site-wide surveys for eight animal species of concern were initiated in 1996 (Steen et al., 1997). The species included chuckwallas (Sauromalus obesus), western burrowing owls (Athene cunicularia hypugaea), and six species of bats (Table 1). For chuckwallas, presence/absence data were gathered from all potential habitats in the southern portion of the NTS. These data were considered sufficient to identify chuckwalla habitat on the NTS (Steen et al., 1997). NNSA/NSO impacts on chuckwalla will be monitored over time by identifying all historic and new projects that have, or will, disturb chuckwalla habitat.

The collection of baseline data on western burrowing owls was completed last fiscal year, and this year's efforts focused on completing the draft report entitled Ecology of the Western Burrowing Owl on the Nevada Test Site. Field data collection this year was restricted to two animal species: bats and wild horses (Equus caballus). Surveys of tunnels, mine shafts, mine adits, and buildings were conducted to identify bat roost sites, and the annual horse population census was conducted. No field surveys to locate or monitor raptor nests were performed, although raptor mortality records were updated and are reported.

\subsubsection{Western Burrowing OwI}

Two new burrow sites of the western burrowing owl were discovered while reviewing historic preactivity survey data and were added to the computerized owl location database. To date, a total of 119 western burrowing owl locations (30 owl sightings and 89 burrow sites) are known to occur on the NTS (Figure 14). Of these 119 locations, 54 percent occur in the transition ecoregion, 32 percent occur in the Mojave Desert ecoregion, 9 percent occur in the Great Basin Desert ecoregion, and 5 percent are at unspecified locations. 


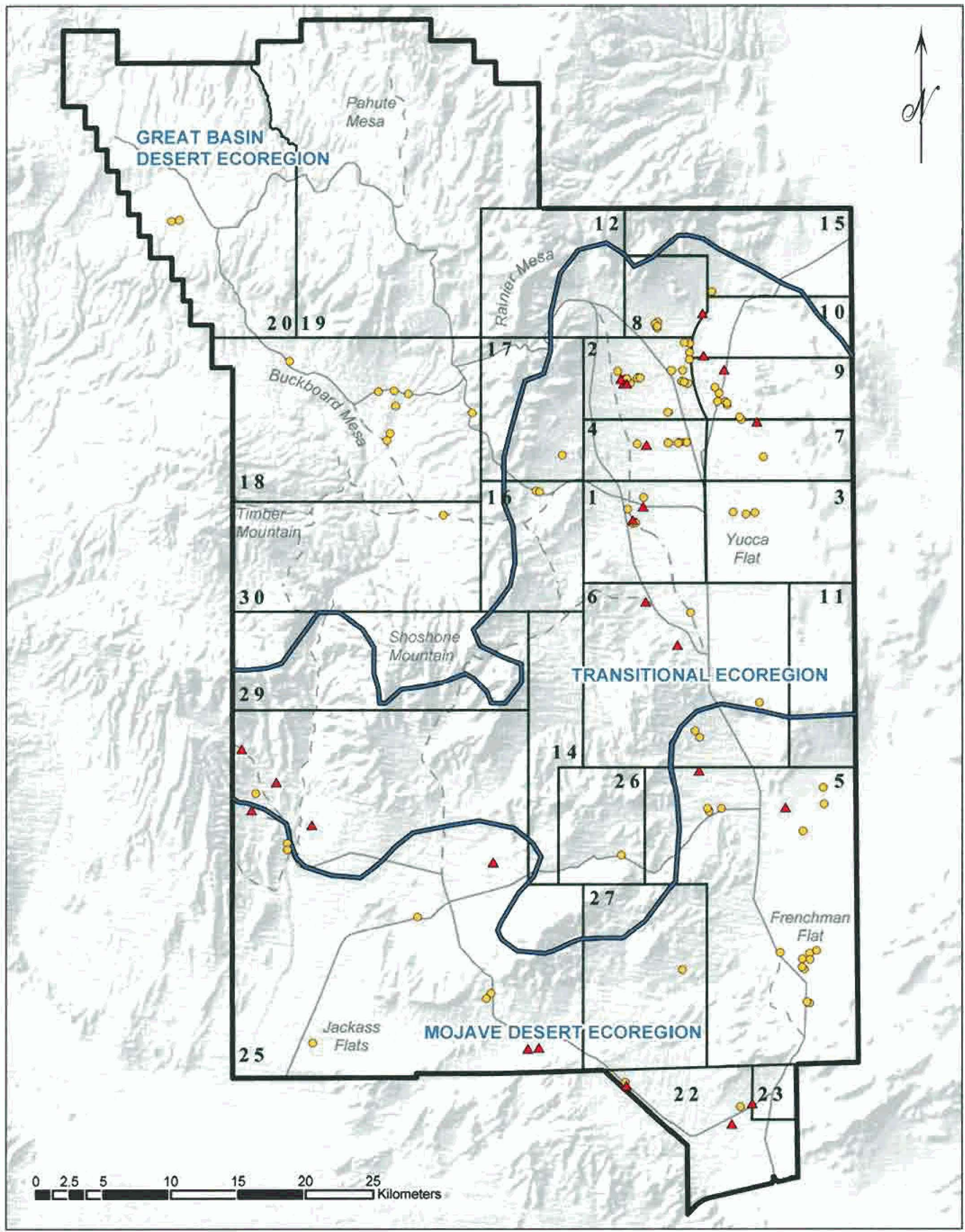
- Burrow Site Ecoregion Boundary
Primary road
$\simeq$ NTS Operational Area
$\sim$ NTS Boundary
$\triangle$ Owl Sighting Secondary road $~$ NTS Boundary 
The document Ecology of the Western Burrowing Owl on the Nevada Test Site

(DOE/NV/11718-701) was completed in fiscal year 2003. The report summarizes the results of more than four years of field data collection pertaining to this species' distribution, burrow use, reproduction and activity patterns, food habits, disturbance effects, and winter burrow temperatures on the NTS. A section of the report addresses current management practices for this species which have been adjusted in response to the ecological information gathered. The document will be distributed in December 2003.

This year the FWS published the document, Status Assessment and Conservation Plan for the Western Burrowing Owl in the United States (Klute et al., 2003). This plan includes a state-by-state summary on this owl. Comments submitted by BN biologists were included in the final publication and contributed significant information to the summary section for Nevada.

\subsubsection{Bat Species of Concern}

This year, 22 sites were monitored for bat use between June 24 and September 3, 2003 (Figures 15 and 16). Four sites were man-made water sources and one was a natural water source. With the exception of E Tunnel Ponds, these water sources had not been previously monitored for bat use. The 17 other sites were potential roost sites. All but one were man-made excavations into rock including vertical shafts and horizontal adits and tunnels. One potential roost site was a cement bunker in Area 6 (CP-11 Bunker), where bat sign was found during biological surveys of buildings scheduled for demolition (see Section 1.0). At most sites, three techniques were used to document bat activity: (1) the use of mistnets set up next to the excavation/structure or water source, (2) recording of ultrasonic echolocation calls of bats flying in or out of excavation/ structure or around water source using the Anabat II system (Titley Electronics, Ballina, Australia), and (3) observing and recording bat activity at each site with a special night vision camera equipped with NightSight ${ }^{\mathrm{TM}}$ technology. Bat use data from the 22 sites expand the known distributions of bats on the NTS and identify man-made structures and excavations which may be critical habitat for bat species of concern.

\subsubsection{Bat Occurrence at Monitored Sites}

Eighteen bats representing five species were captured in mist-nets at seven of the sites monitored (Table 8). A total of nine species were documented as occurring at 21 of the 22 sites monitored based on analysis of recorded files of echolation calls (Table 8). The species captured or detected which were species of concern (Table 1) included the fringed myotis (Myotis thysanodes), longlegged myotis ( $M$. volans), small-footed myotis ( $M$. ciliolabrum), and Townsend's big-eared bat (Corynorhinus townsendii pallescens). Other species detected included the big brown bat (Eptesicus fuscus), the Brazilian free-tailed bat (Tadarida braziliensis), the California myotis (M. californicus), the pallid bat (Antrozous pallidus), and the western pipistrelle bat (Pipistrellus hesperus).

The majority of the bats captured were Townsend's big-eared bats (Figure 17). This species and the fringed myotis have been assigned a status of "high risk" in Nevada based on the Western Bat Species Regional Priority Matrix (Western Bat Working Group, 1998). These species are believed to be imperiled or at high risk of imperilment based on available information about their distributions, population status, ecology, and known threats. 


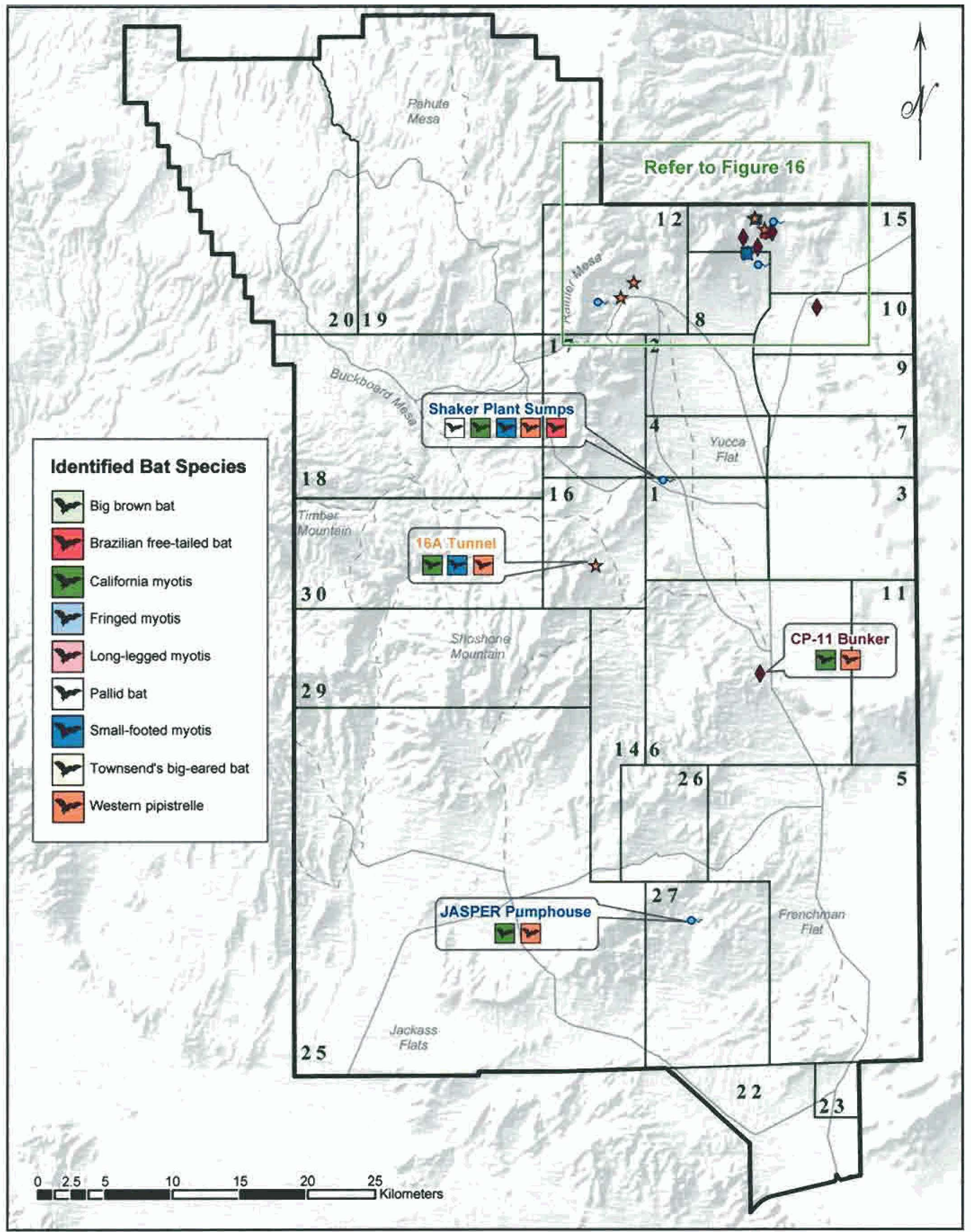

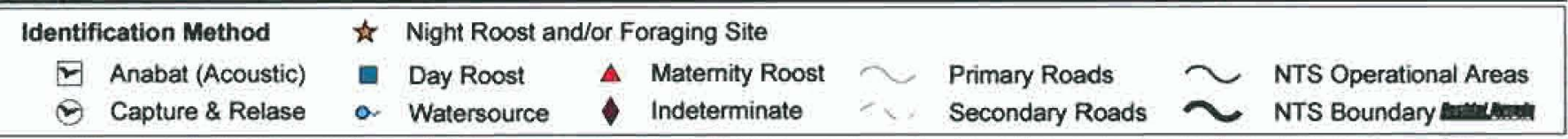

Figure 15. Sites monitored for bat use on the NTS, roost site designations, and species present based on capture and acoustic monitoring data collected during FY 2003 


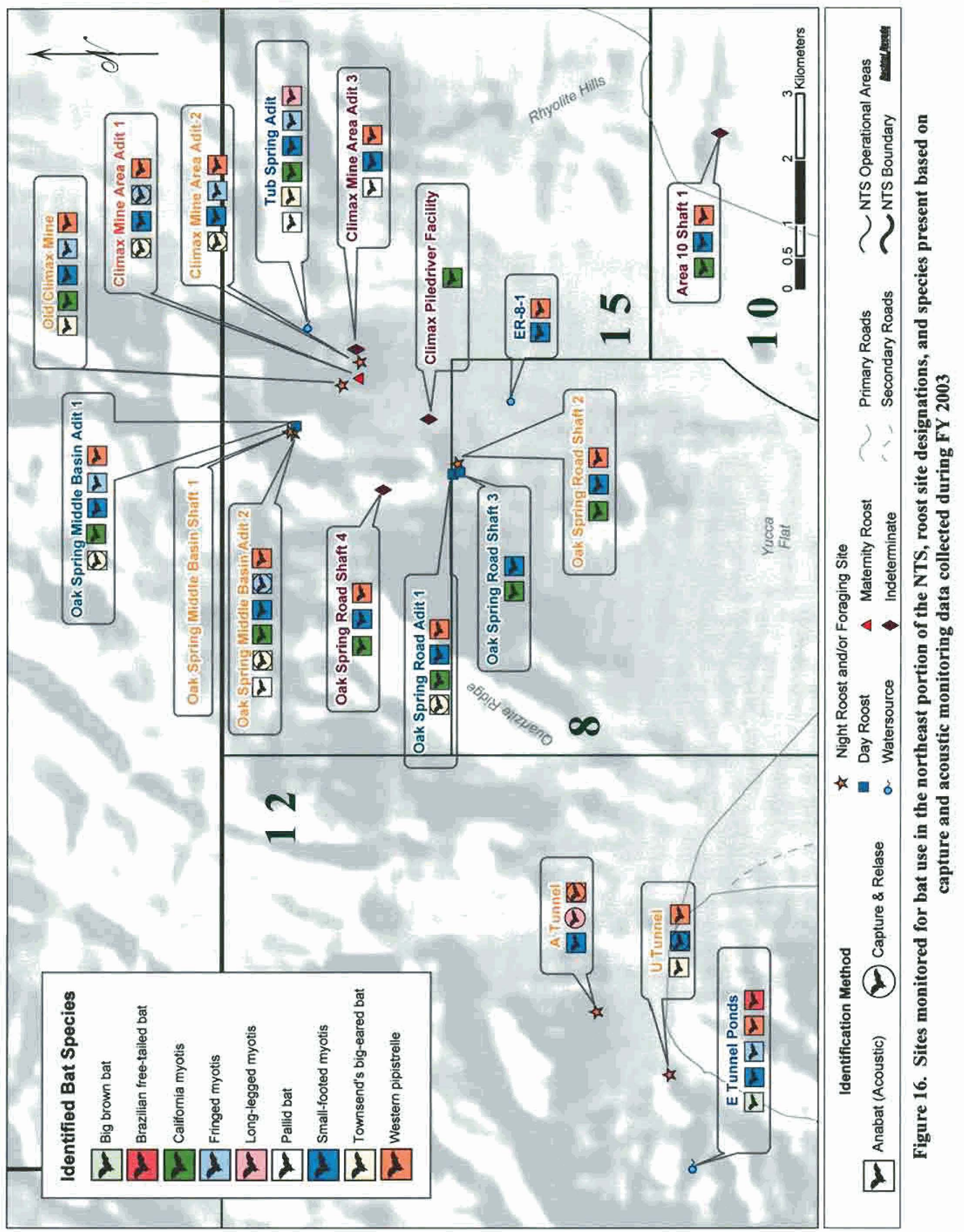


Table 8. Number of bats captured by sex and reproductive condition (in italics) and number of electronic files of bat calls (regular font) at sites monitored in FY 2003

\begin{tabular}{|c|c|c|c|c|c|c|c|c|c|c|}
\hline \multirow[b]{2}{*}{ Location (Monitoring Date[s]) } & \multicolumn{9}{|c|}{ Species } & \multirow[b]{2}{*}{$\begin{array}{c}\text { Total } \\
\text { Number } \\
\text { Electronic } \\
\text { Files } \\
\end{array}$} \\
\hline & $\begin{array}{l}\text { Big } \\
\text { brown } \\
\text { bat }\end{array}$ & $\begin{array}{c}\text { Brazilian } \\
\text { free-tailed } \\
\text { bat }\end{array}$ & $\begin{array}{l}\text { California } \\
\text { myotis }\end{array}$ & $\begin{array}{l}\text { Fringed } \\
\text { myotis** }\end{array}$ & $\begin{array}{l}\text { Long-legged } \\
\text { myotis** }\end{array}$ & $\begin{array}{c}\text { Pallid } \\
\text { bat }\end{array}$ & $\begin{array}{l}\text { Small-footed } \\
\text { myotis** }\end{array}$ & $\begin{array}{c}\text { Townsend's } \\
\text { big-eared } \\
\text { bat** }\end{array}$ & $\begin{array}{c}\text { Western } \\
\text { pipistrelle } \\
\text { bat }\end{array}$ & \\
\hline \multicolumn{11}{|l|}{ Excavations/Structures } \\
\hline 16A Tunnel $(7 / 16)$ & & & 1 & & & & 8 & & 6 & 15 \\
\hline A Tunnel $(7 / 29)$ & & & & & $1 M$ & & 10 & & $1 L F, 13$ & 23 \\
\hline Area 10 Shaft $1(9 / 3)$ & & & 32 & & & & 9 & & 14 & 55 \\
\hline CP-11 Bunker $(7 / 15)$ & & & 3 & & & & & & 6 & 9 \\
\hline Climax Mine Area Adit $1(7 / 23,8 / 4)$ & & & & $I F, 251$ & & & 15 & $\begin{array}{c}4 L F, 2 M \\
43\end{array}$ & 23 & 332 \\
\hline Climax Mine Area Adit $2(8 / 5)$ & & & & 1 & & & 1 & $I M, 12$ & 3 & 17 \\
\hline Climax Mine Area Adit $3(8 / 6)$ & & & & & & 1 & 5 & & 2 & 8 \\
\hline Climax Piledriver Facility $(6 / 24)$ & & & 8 & & & & & & & 8 \\
\hline Oak Spring Middle Basin Adit $1(8 / 26)$ & & & 1 & 7 & & & 3 & $\begin{array}{c}I F, I M, I U \\
10\end{array}$ & 1 & 22 \\
\hline Oak Spring Middle Basin Adit $2(8 / 25)$ & & & 5 & $L L F, 9$ & & 3 & 1 & $I L F, I F, 4$ & 15 & 37 \\
\hline \multicolumn{11}{|l|}{$\begin{array}{l}\text { Oak Spring Middle Basin Shaft } 1 \\
(8 / 26)^{* * *}\end{array}$} \\
\hline Oak Spring Road Adit $1(8 / 18)$ & & & 22 & & & & 1 & $1 F, 2$ & 3 & 28 \\
\hline Oak Spring Road Shaft $2(8 / 20)$ & & & 24 & & & & 3 & & 7 & 34 \\
\hline Oak Spring Road Shaft $3(9 / 2)$ & & & 1 & & & & 2 & & & 3 \\
\hline Oak Spring Road Shaft $4(8 / 27)$ & & & 1 & & & & 3 & & 1 & 5 \\
\hline Old Climax Mine Adit (8/11) & & & 4 & 1 & & & 1 & 2 & 1 & 9 \\
\hline U Tunnel $(7 / 21,7 / 28)$ & & & & & & & $I F, 2$ & 1 & 2 & 5 \\
\hline
\end{tabular}

${ }^{*} \mathrm{~F}=$ Female, $\mathrm{LF}=$ Lactating female, $\mathrm{M}=$ Male, $\mathrm{U}=$ Unknown gender

**species of concern (see Table 1)

***Bats were observed at this site but Anabat II system was not used; no species identifications could be made. 
Table 8. (Continued)

\begin{tabular}{|c|c|c|c|c|c|c|c|c|c|c|}
\hline \multirow[b]{2}{*}{ Location (Monitoring Date[s]) } & \multicolumn{10}{|c|}{ Species } \\
\hline & $\begin{array}{c}\text { Big } \\
\text { brown } \\
\text { bat }\end{array}$ & $\begin{array}{c}\text { Brazilian } \\
\text { free-tailed } \\
\text { bat }\end{array}$ & $\begin{array}{c}\text { California } \\
\text { myotis }\end{array}$ & $\begin{array}{l}\text { Fringed } \\
\text { myotis** }\end{array}$ & $\begin{array}{l}\text { Long-legged } \\
\text { myotis** }\end{array}$ & $\begin{array}{c}\text { Pallid } \\
\text { bat }\end{array}$ & $\begin{array}{l}\text { Small-footed } \\
\text { myotis** }\end{array}$ & $\begin{array}{c}\text { Townsend's } \\
\text { big-eared } \\
\text { bat** }^{* *}\end{array}$ & $\begin{array}{l}\text { Western } \\
\text { pipistrelle }\end{array}$ & $\begin{array}{c}\text { Total } \\
\text { Number } \\
\text { Electronic } \\
\text { Files }\end{array}$ \\
\hline \multicolumn{11}{|l|}{ Water Sources } \\
\hline E Tunnel Ponds (7/28) & 22 & 2 & & 1 & & & 15 & & 31 & 71 \\
\hline ER 8-1 (8/13) & & & & & & & 6 & & 6 & 12 \\
\hline JASPER Pumphouse (7/22) & & & 31 & & & & & & 6 & 37 \\
\hline Shaker Plant Sumps $(8 / 19)$ & & 4 & 1 & & & 1 & 59 & & 142 & 207 \\
\hline Tub Spring/Adit (8/12) & & & 106 & 19 & 6 & 4 & 42 & 7 & & 184 \\
\hline Total Number of Captures & $\mathbf{0}$ & $\mathbf{0}$ & $\mathbf{0}$ & 2 & 1 & $\mathbf{0}$ & 1 & 13 & 1 & \\
\hline Total Number of Electronic Files & 22 & 6 & 240 & 289 & 6 & 9 & 186 & 81 & 282 & 1,121 \\
\hline
\end{tabular}




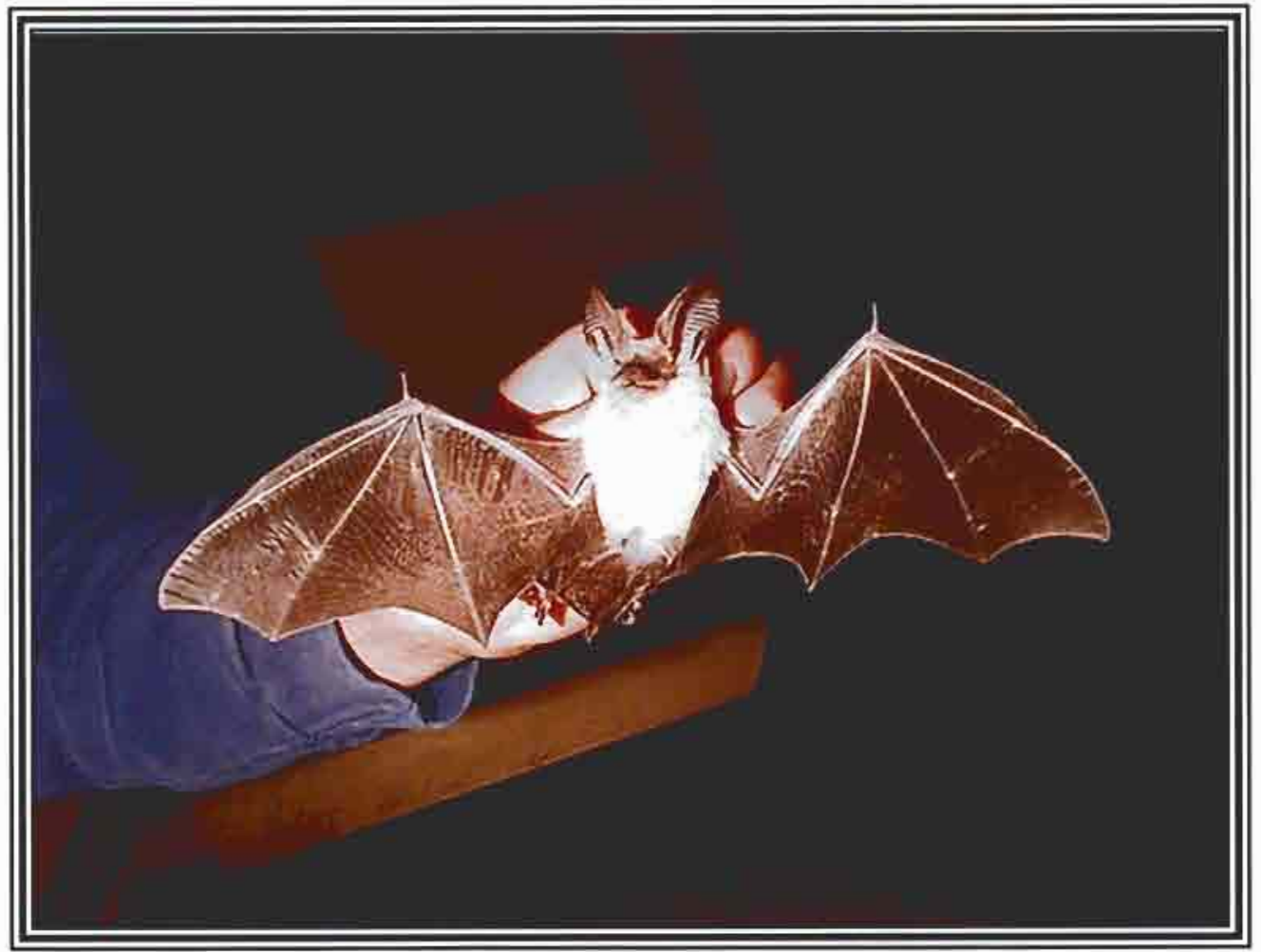

Figure 17. Female Townsend's big-eared bat captured at Oak Spring Middle Basin Adit 2 (photo by W. Kent Ostler, August 25, 2003)

A total of 1,121 electronic files of distinguishable bat ultrasonic calls were collected (Table 8). O'Farrell Biological Consulting analyzed the calls and identified them to species. Nine species were identified. The California myotis, small-footed myotis, and western pipistrelle bat occurred at the most number of sites. More Townsend's big-eared bat call files were collected at more sites than have been collected in previous years. This is due primarily to the fact that previous monitoring focused on water sources only and not potential roost sites. The Townsend's big-eared bat is a cave/mine-roosting obligate. This species has a low intensity call and in order for the Anabat II system to record their calls, the bats must echolocate within $5-10 \mathrm{~m}$ of the Anabat II microphone. Setting up the Anabat II microphone close to excavation openings allowed successful documentation that this sensitive bat species is present in numbers higher than indicated from previous year's monitoring of water sources. Calls were also obtained from 14 hand-released individuals ( 11 Townsend's big-eared bats, 1 small-footed myotis, 1 fringed myotis, and 1 western pipistrelle bat). These files will be added to the existing call library as voucher calls to compare against calls collected in the future.

\subsubsection{Identification of Roost Sites}

Bats are known to have day roosts where they remain from dawn until dusk and night roosts where they rest between foraging forays. Maternity roosts are sites where females give birth and rear their young. Some maternity roosts are communal, containing large colonies of one or more species of bats. The young remain in the roost until they are weaned and lactating females leave the roost only to forage. The location and distribution of maternity roosts on the NTS is valuable information needed to ensure the protection of those species of bats which are sensitive and considered imperiled such as the Townsend's big-eared bat and fringed myotis (Western Bat Working Group, 1998). 
Figure 18 shows bat detection equipment set up outside a mine adit. The mist net captures, visual observations, and Anabat II call data were all examined to determine if the 17 sites (structures/ excavations) are indeed roost sites. Each site was given a bat use designation of M, D, NR/FS, or I according to the following definitions: $\mathrm{M}=$ maternity roost where lactating females were captured in mist nets and bats were seen flying out of the site at dusk, $\mathrm{D}=$ day roost where bats were observed flying out of the site at dusk, NR/FS = night roost and/or foraging site where bats were observed flying in and out of or foraging within the site, and I = of indeterminate use where bats were only observed flying over or around the site and not flying in or out of it. Of the 17 sites, one is a maternity roost, three are day roosts, and eight are night roost/foraging sites (Table 9, Figures 15 and 16).

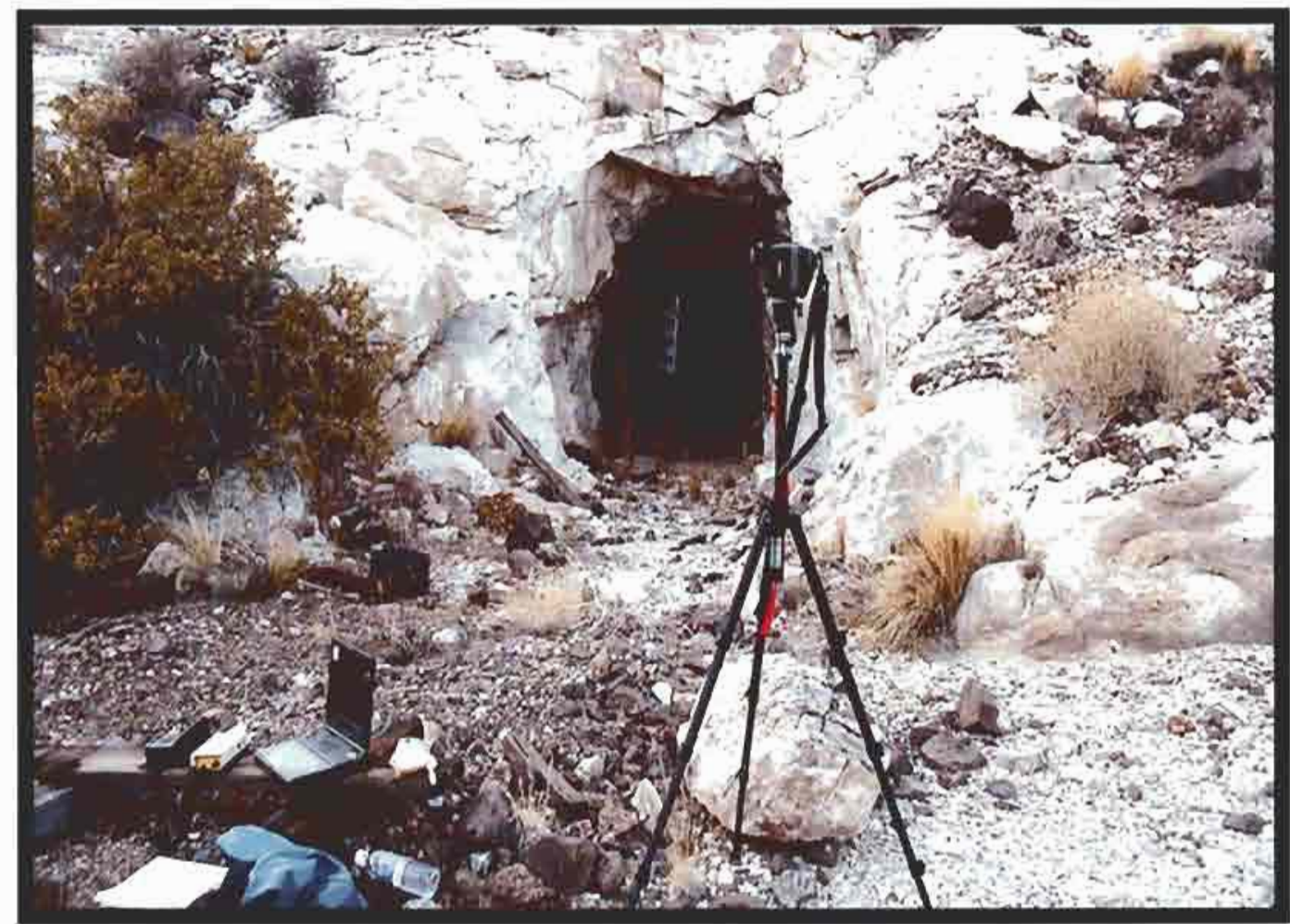

Figure 18. Anabat II system (on ground) and NightSight ${ }^{\mathrm{TM}}$ camera (on tripod) outside the Climax Mine Area Adit 1 (photo by W. Kent Ostler, July 23, 2003)

The Climax Mine Area Adit 1 is a Townsend's big-eared bat maternity roost where four lactating females were captured. Three other species were present at the site, as determined by Anabat II and capture data: the fringed myotis, small-footed myotis, and western pipistrelle (Table 8). This adit may also contain maternity colonies of these species which were not captured, especially the fringed myotis for which 252 calls were recorded. Further sampling is needed over multiple breeding seasons to identify all species using this adit as a maternity roost and to determine roost fidelity.

The Oak Spring Middle Basin Adit 1 was designated as a day roost for Townsend's big-eared bats. At least 65 bats were observed visually and five species were identified as present based on call analysis (Table 8). Three Townsend's big-eared bats were captured late in the breeding season, but none were lactating females. It is possible that this site is also a maternity roost and further monitoring will be done over the next several breeding seasons to verify this. 
Table 9. Bat use designations for all potential roost sites monitored during FY 2003

\begin{tabular}{|c|c|c|c|}
\hline Location & $\begin{array}{c}\text { Use } \\
\text { Designation }^{1}\end{array}$ & Observations $^{2}$ & $\begin{array}{c}\text { Number } \\
\text { of Species } \text { Present }^{3}\end{array}$ \\
\hline 16A Tunnel & $\mathrm{N} / \mathrm{FS}$ & $\begin{array}{l}\text { Bats flying in and out of tunnel and foraging } \\
\text { inside tunnel }\end{array}$ & 3 \\
\hline A Tunnel & N/FS & $\begin{array}{l}\text { Bats flying in and out of tunnel and foraging } \\
\text { inside tunnel, one lactating western pipistrelle } \\
\text { captured but no bats observed exiting at dusk }\end{array}$ & 3 \\
\hline Area 10 Shaft 1 & I & Bats flying over shaft & 3 \\
\hline CP-11 Bunker & I & Bats flying around door & 2 \\
\hline Climax Mine Area Adit 1 & $\mathbf{M}$ & $\begin{array}{l}\text { Four lactating Townsend's big-eared bats } \\
\text { captured, bats exiting adit at dusk }\end{array}$ & 4 \\
\hline Climax Mine Area Adit 2 & N/FS & $\begin{array}{l}\text { Bats flying in and out of adit and foraging } \\
\text { inside adit }\end{array}$ & 4 \\
\hline Climax Mine Area Adit 3 & I & Bats flying over adit & 3 \\
\hline Climax Piledriver Facility & I & Bats flying around tower & 1 \\
\hline Oak Spring Middle Basin Adit 1 & $\mathrm{D}$ & $\begin{array}{l}\text { Three Townsend's big-eared bats captured, } \\
\text { bats exiting adit at dusk }\end{array}$ & 5 \\
\hline Oak Spring Middle Basin Adit 2 & $\mathrm{~N} / \mathrm{FS}$ & $\begin{array}{l}\text { Bats flying in and out of adit and foraging } \\
\text { inside adit, one lactating fringed myotis and } \\
\text { one lactating Townsend's big-eared bat } \\
\text { captured but no bats observed exiting at dusk }\end{array}$ & 6 \\
\hline Oak Spring Middle Basin Shaft 1 & $\mathrm{~N} / \mathrm{FS}$ & $\begin{array}{l}\text { Bats flying in and out of shaft and foraging } \\
\text { inside of shaft }\end{array}$ & $\mathrm{NA}^{4}$ \\
\hline Oak Spring Road Adit 1 & $\mathrm{D}$ & Bats exiting adit at dusk & 4 \\
\hline Oak Spring Road Shaft 2 & $\mathrm{~N} / \mathrm{FS}$ & Bats flying in and out of shaft & 3 \\
\hline Oak Spring Road Shaft 3 & $\mathrm{D}$ & Bats exiting shaft at dusk & 2 \\
\hline Oak Spring Road Shaft 4 & I & Bats flying past shaft & 3 \\
\hline Old Climax Mine Adit & $\mathrm{N} / \mathrm{FS}$ & $\begin{array}{l}\text { Bats flying in and out of adit and foraging } \\
\text { inside adit }\end{array}$ & 5 \\
\hline U Tunnel & $\mathrm{N} / \mathrm{FS}$ & Bat flying into tunnel & 3 \\
\hline
\end{tabular}

${ }^{1} \mathrm{D}=$ day roost, $\mathrm{I}=$ of indeterminate use, $\mathrm{M}=$ maternity roost, $N / F S=$ night roost and/or foraging site

${ }^{2}$ Observations used for designating roost type; based on mist net captures and observations with NightSight ${ }^{\mathrm{TM}}$ camera and night vision goggles

${ }^{3}$ Based on analysis of recorded ultrasonic bat calls with Anabat II system and on captures

${ }^{4} \mathrm{NA}=$ Not applicable, Anabat II system was not used at this site 


\subsubsection{Reported Day Roosts}

Bats in or around buildings were found on two occasions by NTS workers who then contacted Ecological Services biologists. One bat (either a California or small-footed myotis) was found day roosting under the porch at Building 117 in Mercury. It left the next day. A male California myotis was found day roosting in Building 190 in Mercury and was collected as a voucher specimen. Results from biological surveys of buildings and reports by others of bats in buildings enables $\mathrm{BN}$ biologists to increase their knowledge about bat roosting sites on the NTS. Roost site locations will continue to be documented and stored in the EGIS faunal database.

\subsubsection{Installation of Passive Acoustic Monitoring System}

Bat monitoring is scheduled to continue over the next several years to identify roosts and to better define the distribution of bat species on the NTS. There remain many more man-made and natural potential roost sites that need sampling. To increase the speed of "screening" such sites to determine if bats even occur at them, and to keep labor costs of field activities low, a passive acoustic monitoring system is necessary.

This year, a contract was set up with O'Farrell Biological Consulting to design and build two passive acoustic monitoring systems, a portable passive unit and a long-term stationary unit. Both systems were built and delivered to BN biologists in September. The passive portable unit will be used beginning next fiscal year to monitor bat activity at various locations across the NTS. At those sites where the unit is left and later retrieved and where the unit recorded bat calls, a biologist will return with mist nets, NightSight ${ }^{\mathrm{TM}}$ camera, and the Anabat II system to determine how bats use the sites. The long-term stationary unit will be used at a site to examine seasonal patterns of bat use and long-term trends in bat use.

In late September, the long-term unit was set up at Camp 17 Pond with the aid of O'Farrell Biological Consulting. The system is set up so that bat calls are saved to a compact flash card which will be replaced every two to four weeks. Call files will be uploaded from the flash card to a computer and submitted to O'Farrell Biological Consulting for species identification. As of the end of this fiscal year, acoustic data from the unit have not been gathered or analyzed.

\subsubsection{Coordination With Other Wildlife Agencies/Biologists}

A BN biologist attended a meeting of the Nevada Bat Working Group in February 2003. Several state and federal agency personnel were in attendance to discuss issues concerning the Nevada Bat Conservation Plan. The intent of the meeting was to come to a resolution on some language contained in the plan so different agencies would consent to sign the document. The BN biologist provided input as one of the contributing authors to the Nevada Bat Conservation Plan, which was published and distributed in July 2002 (Altenbach et al., 2002). Information from bat monitoring on the NTS was included in the plan.

\subsubsection{Wild Horses}

Horse monitoring continued this year to provide information on the abundance, recruitment (i.e., survival of horses to reproductive age), and distribution of the horse population on the NTS. 
Information on abundance and recruitment during 1990-1998 is summarized in Greger and Romney (1999). In FY 2003, BN biologists determined horse abundance and recorded horse sign along roads. Also, selected natural and man-made water sources were visited in the summer to determine their influence on horse distribution and movements and document the impact horses are having on NTS wetlands.

\subsubsection{Abundance Survey}

A count of individual horses was taken to estimate abundance. The count was conducted during 18 non-consecutive days between May and September. A standard road course was driven to locate and identify horses. Individuals were identified by their unique physical markings. The direct population count in FY 2003 was 30 individuals and does not include foals (Table 9). Six foals were observed with their mares from June-August. Only one of the five foals observed last year survived to yearling age, however it was found dead this year. One old ( $>14$ years of age) male was also found dead this year, and the remains of an additional unidentified adult horse was found at Little Wildhorse Seep in Area 30. One adult male and one adult female that were observed last year were not observed this year.

From 1995 to 1998, the feral horse population declined 31 percent, from 54 to 37 adults (Table 9). Low foal survival continues on the NTS. Only 6 of 40 foals (15 percent) observed from 1998 through 2002 were observed as yearlings. The overall population declines from 1995 is mainly the result of poor foal survival and no immigration of new adults. Also, older male horses have tended to disappear from the population over time, with only eight males presently known in the NTS population (Table 9). It is not known how much of this decline in the population is due to mortality versus emigration.

Poor recruitment of younger horses (if it continues) will lead to an aging horse population, and older horses are more susceptible to death from drought-related stress than young horses. Old horses that are past their prime reproductive age also have lower foal production. Over the past ten years, the causes of mortality among adult horses have included predation (one), collisions with vehicles (two), drowning (one), and unknown (four). Among young horses (1-2 year olds), two have died from unknown causes and one presumably from dehydration at a dried up spring. Many previously identified horses have not been observed for years and are presumed dead.

\subsubsection{Annual Range Survey}

During FY 2003, selected roads were driven within and along the boundaries of the suspected annual horse range and all fresh sign (estimated to be $<1$ year old) located on and adjacent to the roads were recorded. Eight days of effort were expended for the road surveys. Horse sign data collected during the road surveys and horse use at natural and man-made water sources indicate that the FY 2003 NTS horse range includes Gold Meadows, Yucca Flat, Eleana Range, southwest foothills of the Eleana Range, and southeast Pahute Mesa (Figure 19). Overall, the annual horse range appears to be reduced slightly from previous years due to smaller population size. During the summer, horses are dependent on Captain Jack Spring, the only known water source in the Eleana Range (Figure 19). Man-made water sources on Yucca Flat have been removed in past years, and the increased distances horses must travel back and forth to Captain Jack Spring probably limits the herds grazing range to the north and east. In addition, the risk of mountain lion predation is greater for those horses returning to the Eleana Range to drink. 
Table 9. Number of horse individuals observed on the NTS by age class, gender, and year since 1995

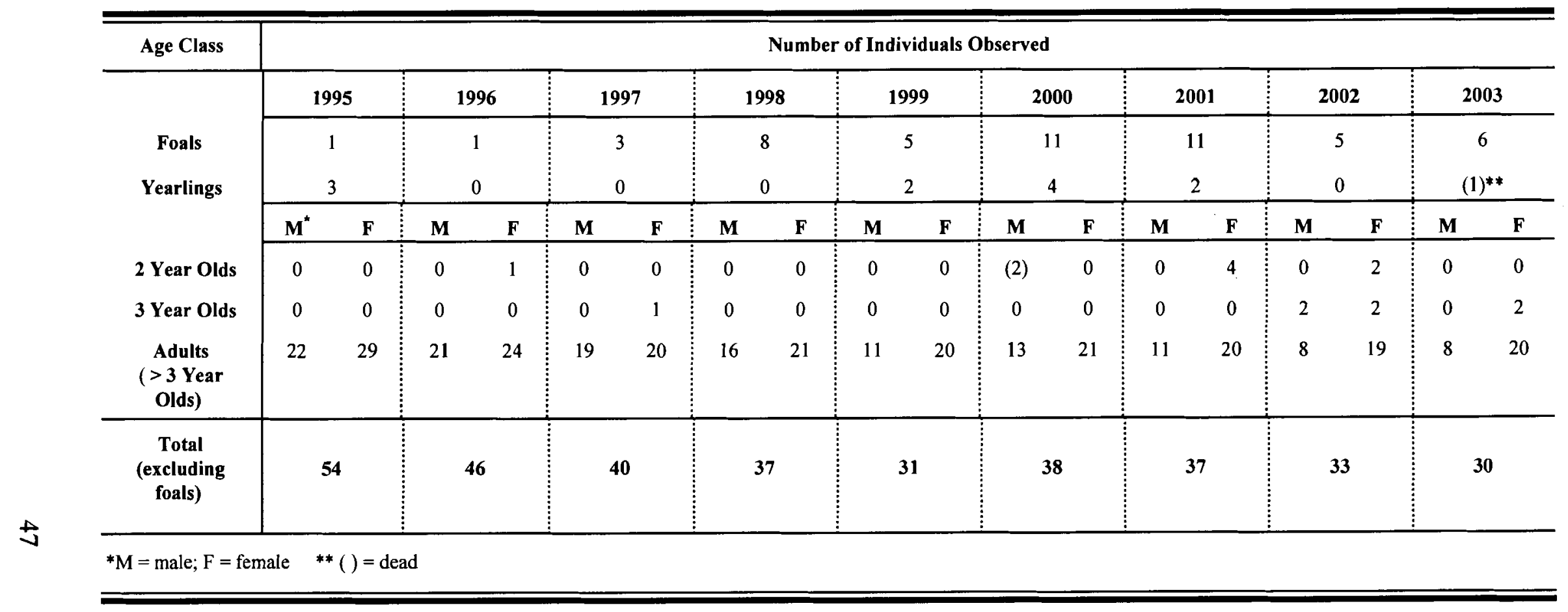




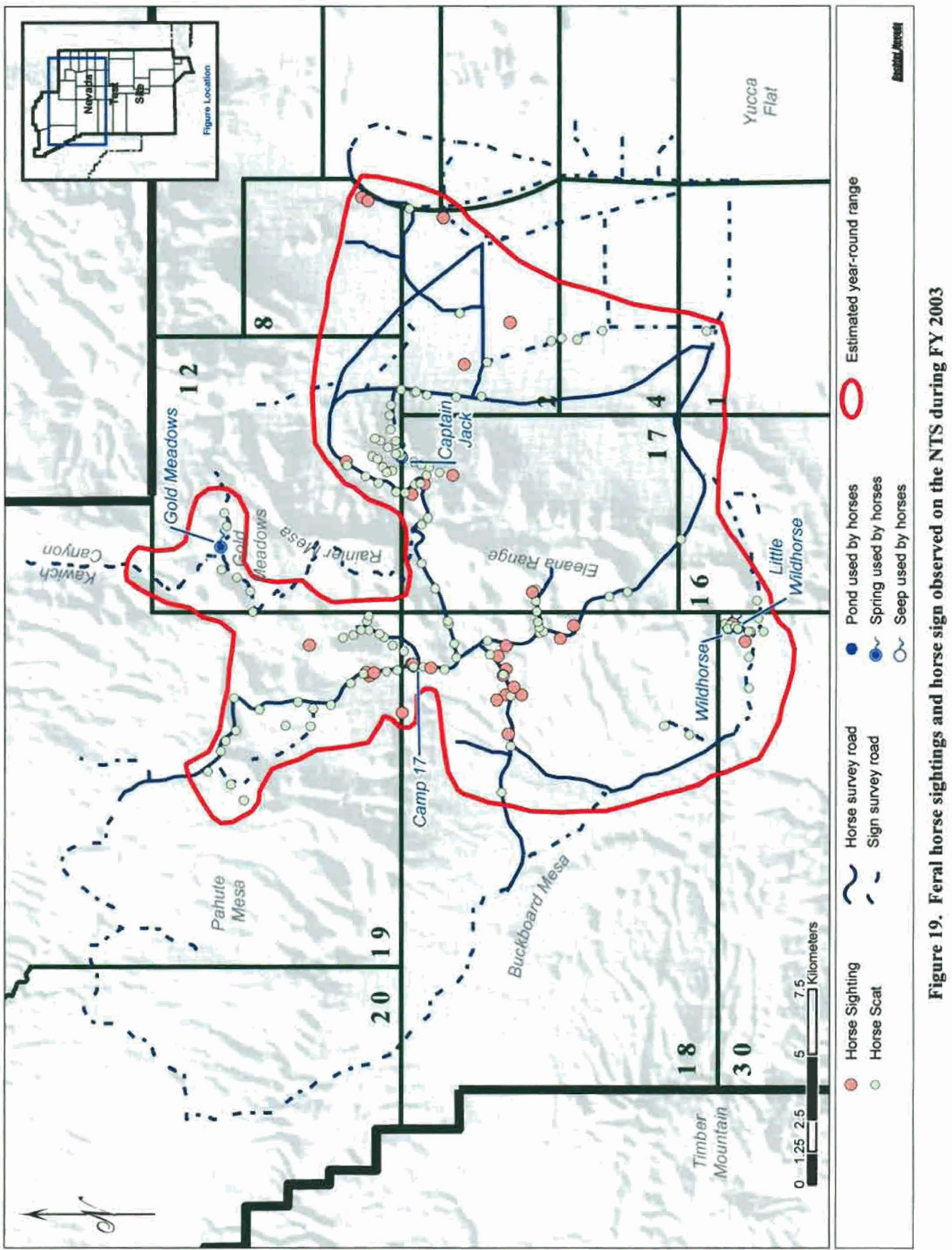


As in previous years, the horse herd appears to consist of two components; one larger group of horses (about 20 individuals) that spends summers west of the Eleana Range and one smaller group (7-10 individuals) that summers east of the Eleana Range on Yucca Flat. These groups of horses probably intermix during the winter in the Eleana Range. Horses were observed in 2001 and 2002 in the Eleana Range during the winter season (December-February) and suggests that horses do not move off the NTS during the winter.

\subsubsection{Use of NTS Water Sources}

The NTS horse population is dependent on several natural and man-made water sources in Areas 18, 12, and 30 (Figure 19) during different seasons. Man-made water source availability has not changed greatly over the last seven years. Wildhorse and Little Wildhorse seeps, both located in Area 30, are important winter-spring water sources. Two other natural water sources (Captain Jack Spring in Area 12, Gold Meadows Spring in Area 12) and one man-made pond (Camp 17 Pond in Area 18) were used by horses this summer, as in past years. Overall, Captain Jack Spring and Camp 17 Pond were the most important summer-fall water sources for horses based on the presence and quantity of horse sign and trampled and grazed vegetation. Horses often use ephemeral water sources in winter such as rock tanks and natural pools that collect water from rain and snowmelt. They appear to be much less dependent on man-made sources in winter.

Wildhorse and Little Wildhorse seeps were used by several bands of horses during the spring of 2003 (as in previous years) when water was available. Horse usage declined during early summer as these springs dried up. Gold Meadows Spring was dry during July - September 2003 due to low summer rainfall in the area. Horses in this region were totally dependent on Camp 17 Pond for the remainder of the summer.

As in past years, none of the man-made ponds or the plastic-lined sumps within or on the edge of the annual horse range (see Section 5.3.2, Figure 21) were used this year. No horse sign have ever been found at these ponds, suggesting that horses do not drink from them.

\subsubsection{Raptors}

Several raptors occur and breed on the NTS which are not protected under the ESA and are not species of concern. They are, however, protected by the federal government under the Migratory Bird Treaty Act and by the state of Nevada. Raptors include all vultures, hawks, kites, eagles, ospreys, falcons, and owls. Because these birds occupy high trophic levels of the food chain, they are regarded as sensitive indicators of ecosystem stability and health. Including the western burrowing owl, there are nine raptors which are known to breed on the NTS (Greger and Romney, 1994).

In FY 2003, no surveys to locate new raptor nests and no monitoring of historical nests were conducted. No active raptor nests were found this year during searches of buildings scheduled for demolition (see Section 2.0). Raptor breeding will be periodically monitored at least once every three years. Three raptor mortalities were documented this year: an electrocuted greathorned owl, an electrocuted red-tailed hawk, and a road-killed western burrowing owl. Over the last 14 years, from 1990 to 2003, 34 incidents of dead raptors have been recorded (Table 10). 
The known causes of death include road-kills, electrocutions, drownings, predation, and entrapment in buildings. Also, seven chicks and seven adult birds have been found dead of unknown causes.

Table 10. Summary of NTS raptor mortality records from 1990-2003

\begin{tabular}{|c|c|c|c|c|c|c|c|c|}
\hline Species & 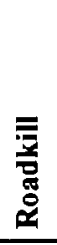 & 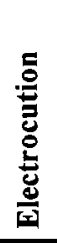 & 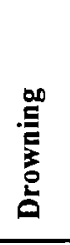 & 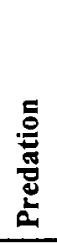 & 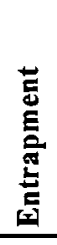 & 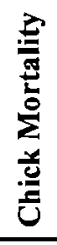 & 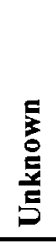 & \\
\hline American kestrel & & & & 1 & 1 & 3 & 2 & 7 \\
\hline Barn owl & 1 & & & 1 & 1 & 3 & 1 & 7 \\
\hline Golden eagle & 1 & 1 & & & & & 1 & 3 \\
\hline Great-horned owl & 3 & 2 & & & & 1 & & 6 \\
\hline Prairie falcon & & & & 1 & & & & 1 \\
\hline Red-tailed hawk & 2 & 2 & 1 & & & & 1 & 6 \\
\hline Sharp-shinned hawk & & & & & & & 1 & 1 \\
\hline Turkey vulture & & & & & & & 1 & 1 \\
\hline Western burrowing owl & 1 & & 1 & & & & & 2 \\
\hline Totals & 8 & 5 & 2 & 3 & 2 & 7 & 7 & 34 \\
\hline
\end{tabular}

\subsection{Wetlands and Wildlife Water Sources}

Natural wetlands and man-made water sources on the NTS provide unique habitats for mesic and aquatic plants and animals and attract a variety of other wildlife. Natural NTS wetlands may qualify as jurisdictional wetlands under the Clean Water Act (CWA). Characterization of these mesic habitats to determine their status under the CWA, and periodic monitoring of their hydrologic and biotic parameters were started in FY 1997 as components of EMAC. Periodic wetland monitoring may help identify annual fluctuations in measured parameters that are natural and unrelated to NNSA/NSO activities. Also, if a spring classified as a jurisdictional wetland were to be unavoidably impacted by an NNSA/NSO project, mitigation for the loss of wetland habitat would be required under the CWA. Under these circumstances, wetland hydrology, habitat quality, and wildlife usage data collected at the impacted spring over several previous years can help to develop a viable mitigation plan and demonstrate successful wetland mitigation.

Man-made excavations constructed to contain water occur on the NTS and also attract wildlife. Along with natural water sources, these man-made sources can affect the movement patterns of some species (e.g., wild horses). However, they can also cause accidental wildlife mortalities from entrapment and drowning if not properly constructed or maintained. Quarterly visits to these water sources were conducted in FY 2003 to document wildlife use and mortality. 


\subsubsection{Wetlands Monitoring}

Monitoring of selected wetlands continued this fiscal year to characterize seasonal baselines and trends in physical and biological parameters. Thirteen wetlands were visited at least once during the year to record the presence/absence of land disturbance, water flow rates, and surface area of standing water (Table 11, Figure 20). Wildlife use data collected at these water sources are shown in Table 12. Due to increased rainfall received this summer, a larger number of bird species (17) and a greater number of total birds ( $>556)$ were observed this year compared to the number of bird species (10) and total numbers of birds (92) observed last year.

Table 11. Seasonal data from selected natural water sources on the NTS collected during FY 2003

\begin{tabular}{|c|c|c|c|c|}
\hline Water Source & Date & $\begin{array}{c}\text { Surface Area } \\
\text { of Water }\left(\mathrm{m}^{2}\right)^{a}\end{array}$ & $\begin{array}{l}\text { Surface Flow } \\
\text { Rate (L/Min) } \\
\end{array}$ & Disturbance at Spring \\
\hline Cane Spring & $06 / 06$ & 6 & 0.2 & None \\
\hline Captain Jack Spring & $08 / 05$ & 20 & 0.9 & Horse grazing and trampling \\
\hline Gold Meadows Spring & $05 / 29$ & 0 & 0 & Horse grazing and trampling \\
\hline Little Wildhorse Seep & $05 / 28$ & 0.3 & 0 & Horse grazing and trampling \\
\hline Pahute Pond & $09 / 04$ & 0 & 0 & None \\
\hline Reitmann Seep & $07 / 29$ & 0.2 & 0 & None \\
\hline Tippipah Spring & $06 / 05$ & 195 & $\mathrm{NM}^{\mathrm{c}}$ & None \\
\hline Tippipah Spring & $09 / 03$ & 165 & NM & None \\
\hline Tub Spring & $06 / 19$ & 0.1 & NM & None \\
\hline Wahmonie Seep No. 1 & $09 / 03$ & 0 & 0 & None \\
\hline Wahmonie Seep No. 4 & $09 / 03$ & 0 & 0 & None \\
\hline Whiterock Spring & $07 / 29$ & 2 & 1.9 & None \\
\hline Wildhorse Seep & $05 / 28$ & 3.0 & 0 & Horse grazing and trampling \\
\hline Yucca Playa Pond & $09 / 03$ & 11,500 & $N^{d}{ }^{d}$ & None \\
\hline $\begin{array}{ll}{ }^{a} \mathrm{~m}^{2}- & \text { Square meters } \\
{ }^{b} \mathrm{~L} / \mathrm{min}- & \text { Liters per minute } \\
{ }^{\mathrm{c}} \mathrm{NM}- & \text { Not measurable d } \\
{ }^{\mathrm{d}} \mathrm{NA}- & \text { Not applicable }\end{array}$ & diffuse & & & \\
\hline
\end{tabular}




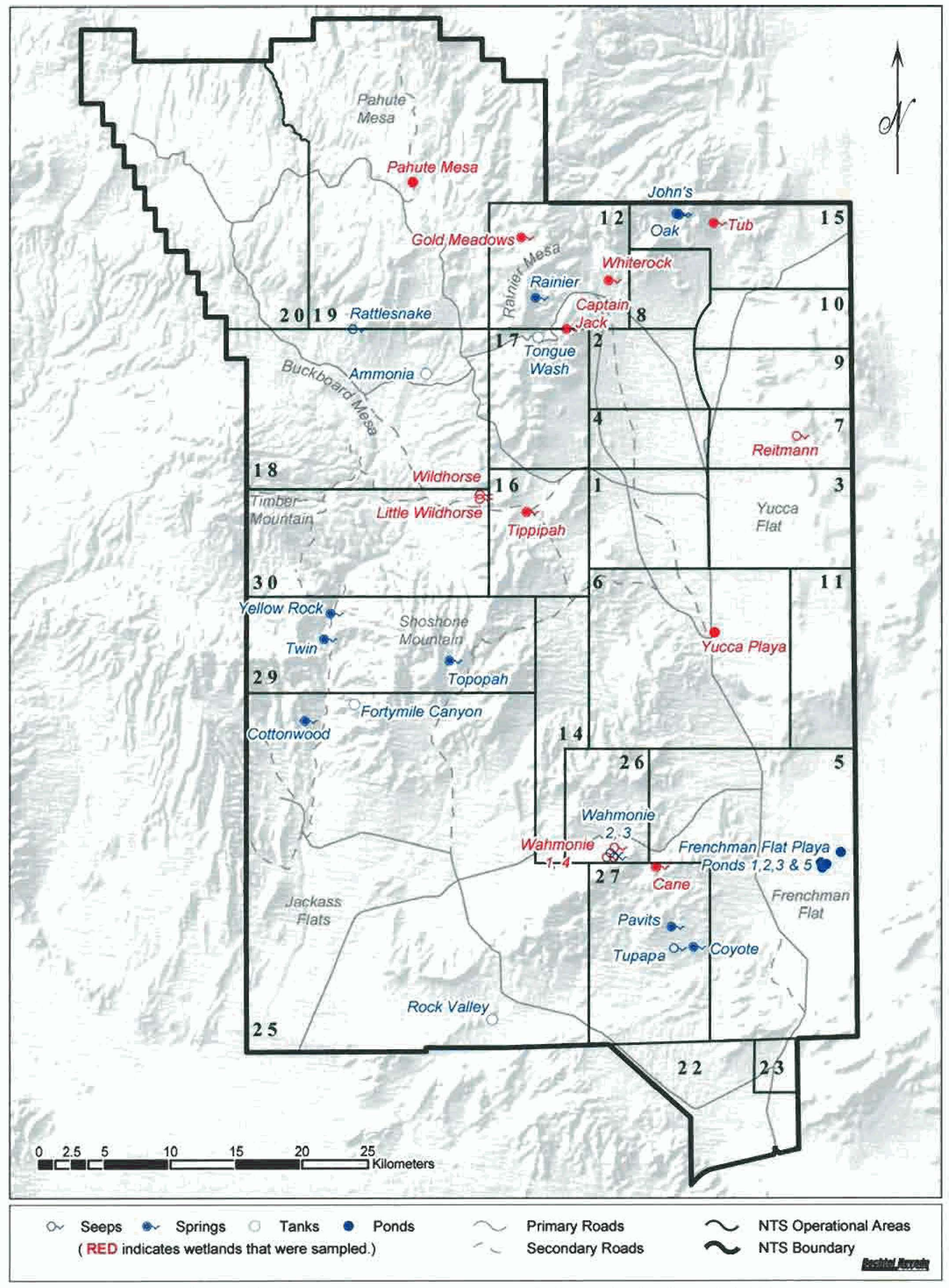

Figure 20. Natural water sources on the NTS sampled during FY 2003 
Table 12. Wildlife observed at selected NTS natural water sources* (date of observations shown below name of water source) during FY 2003

\begin{tabular}{|c|c|c|c|c|c|c|c|c|c|c|c|c|}
\hline & 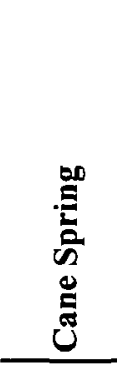 & 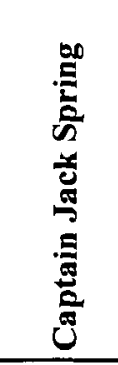 & 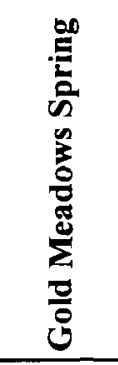 & 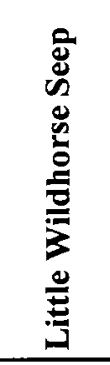 & 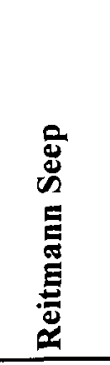 & 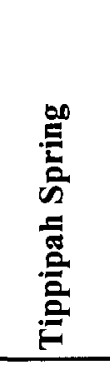 & 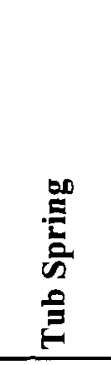 & 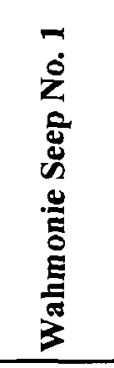 & 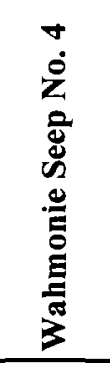 & 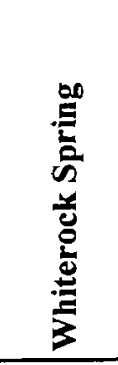 & 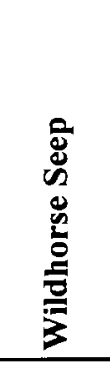 & 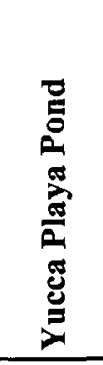 \\
\hline Species Observed & $06 / 16$ & $08 / 05$ & $05 / 29$ & $05 / 28$ & $07 / 29$ & $06 / 05$ & $06 / 19$ & $09 / 03$ & $09 / 03$ & $07 / 29$ & $05 / 28$ & 09/04 \\
\hline \multicolumn{13}{|l|}{ Mammals } \\
\hline Coyote (Canus latrans) & $\mathrm{P}^{* *}$ & $\mathrm{P}$ & $P$ & $\mathbf{P}$ & $\mathbf{P}$ & $\mathbf{P}$ & & $P$ & $P$ & $\mathbf{P}$ & $\mathbf{P}$ & $P$ \\
\hline Feral horse (Equus caballus) & & $P$ & $P$ & $1^{* * *}$ & & & & & & & $\mathbf{P}$ & \\
\hline Mule deer (Odocoileus hemionus) & $P$ & $P$ & $P$ & $\mathrm{P}$ & & $P$ & $P$ & $P$ & $P$ & $\mathbf{P}$ & $\mathbf{P}$ & $\mathbf{P}$ \\
\hline \multicolumn{13}{|l|}{ Birds } \\
\hline American avocet (Recurvirostra americana) & & & & & & & & & & & & 6 \\
\hline Ash-throated flycatcher (Myriachis cinerascens) & & & & & & 1 & & & & & & \\
\hline Black-throated sparrow (Amphispiza bilineata) & $>2$ & 20 & & $>2$ & 1 & 3 & 4 & & & 3 & & \\
\hline Blue winged teal (Anas discors) & & & & & & & & & & & & 5 \\
\hline Brewer's sparrow (Spizella breweri) & & 3 & & & & & & & & & & \\
\hline Bullock's Oriole (Icterus bullockii) & & 2 & & & & & & & & & & \\
\hline Chukar (Alectoris chukar) & & 50 & & & & & & & $P$ & & & \\
\hline Common bushtit (Psaltriparus minimus) & & 3 & & & & & & & & & & \\
\hline Gambel's quail (Calipepla gambelii) & 2 & & & & & & & & & $>80$ & & \\
\hline Greater yellowlegs (Tringa melanoleuca) & & & & & & & & & & & & 1 \\
\hline House Finch (Carpodacus mexicanus) & & 3 & 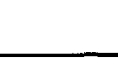 & 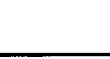 & & & & & & & & \\
\hline
\end{tabular}


Table 12. (Continued)

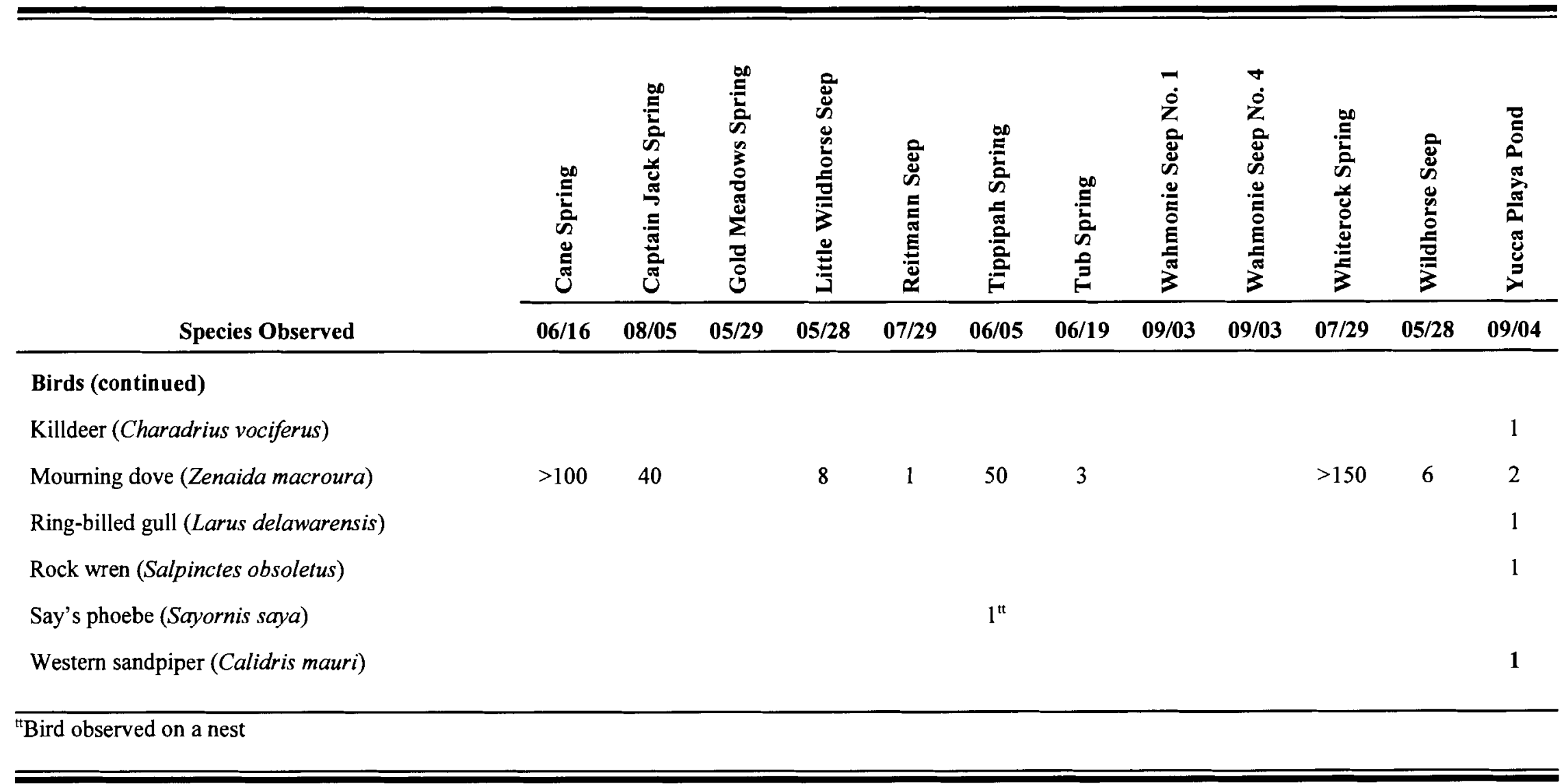




\subsubsection{Monitoring of Man-made Water Sources}

BN biologists conducted quarterly monitoring of man-made water sources. These sources, located throughout the NTS (Figure 21), include 35 plastic-lined sumps, 9 sewage treatment ponds, 8 unlined well ponds, and 2 radioactive containment ponds. Several ponds or sumps are located next to each other at the same project site. Many animals rely on these man-made structures as sources of free water. Wildlife and migratory birds may drown in steep-sided or plastic-lined sumps as a result of entrapment, or ingest contaminants in drill-fluid sumps or evaporative ponds. Ponds are monitored to assess their use by wildlife and to develop and implement mitigation measures to prevent them from causing significant harm to wildlife.

Man-made water sources were visited during four quarterly sampling periods: December 2002, March, June, and September 2003. Sewage ponds and well reservoirs were visited once annually in June. At each site, a BN biologist recorded the presence or absence of standing water and the presence of animals or their sign around the water source. Dirt ramps or plastic ladders, which allow animals to escape if they fall in, have been installed at many plastic-lined sumps, and the presence, absence, and condition of these structures were also noted. All dead animals (or any remains of an animal) in or adjacent to a man-made water source are recorded.

During FY 2003, use of unlined sumps and ponds by waterfowl (ducks, shorebirds), doves, passerine birds (ravens, horned larks, house finches), was increased over last year. Mourning doves were particularly high in number at many water sources during spring-summer. Birds were observed much less at the plastic-lined sumps compared to the unlined ponds.

About 25 dead doves were detected at water sources this year. About one third of these birds appeared to be killed by predators and the other two thirds appeared to die from trichomoniasis (a disease caused by a microscopic protozoan parasite found in bird saliva and crop milk). The disease, which occurs mainly in doves and pigeons, causes abnormal tissue growths in the throats and crops of birds infected with the protozoan. These growths gradually increase in size, causing complete blockage of the esophagus and throat which prevents normal foraging and swallowing, resulting in death by starvation and/or dehydration. The disease is rapidly spread to well birds via water which has been infected with the protozoan when sick birds drink. Dove die-offs during the hot summer months are reported often in southern Nevada when densities of birds are high around limited water sources (e.g., backyard bird baths).

Fifteen dead doves at a water puddle adjacent to an Area 27 pumphouse were reported in June to BN biologists by NTS workers. Dove carcasses at the water puddle were examined by biologists but were too decomposed to identify throat lesions typical of trichomoniasis. However, two dove carcasses, one found at the Mercury Sewage Pond and one at the Well 5B Pond during the same time period, were examined and found to have signs of trichomoniasis. BN biologists consulted with the Nevada Division of Wildlife and the USGS National Wildlife Health Center. Based on consultation and literature review, it was determined that the water puddle was infected with the protozoan. No bird autopsies were performed, however, to confirm this.

No dead animals were recorded in any plastic-lined sumps during FY 2003. Dirt ramps, where installed, appear to be functioning well allowing large mammals to use plastic sumps without becoming entrapped. 


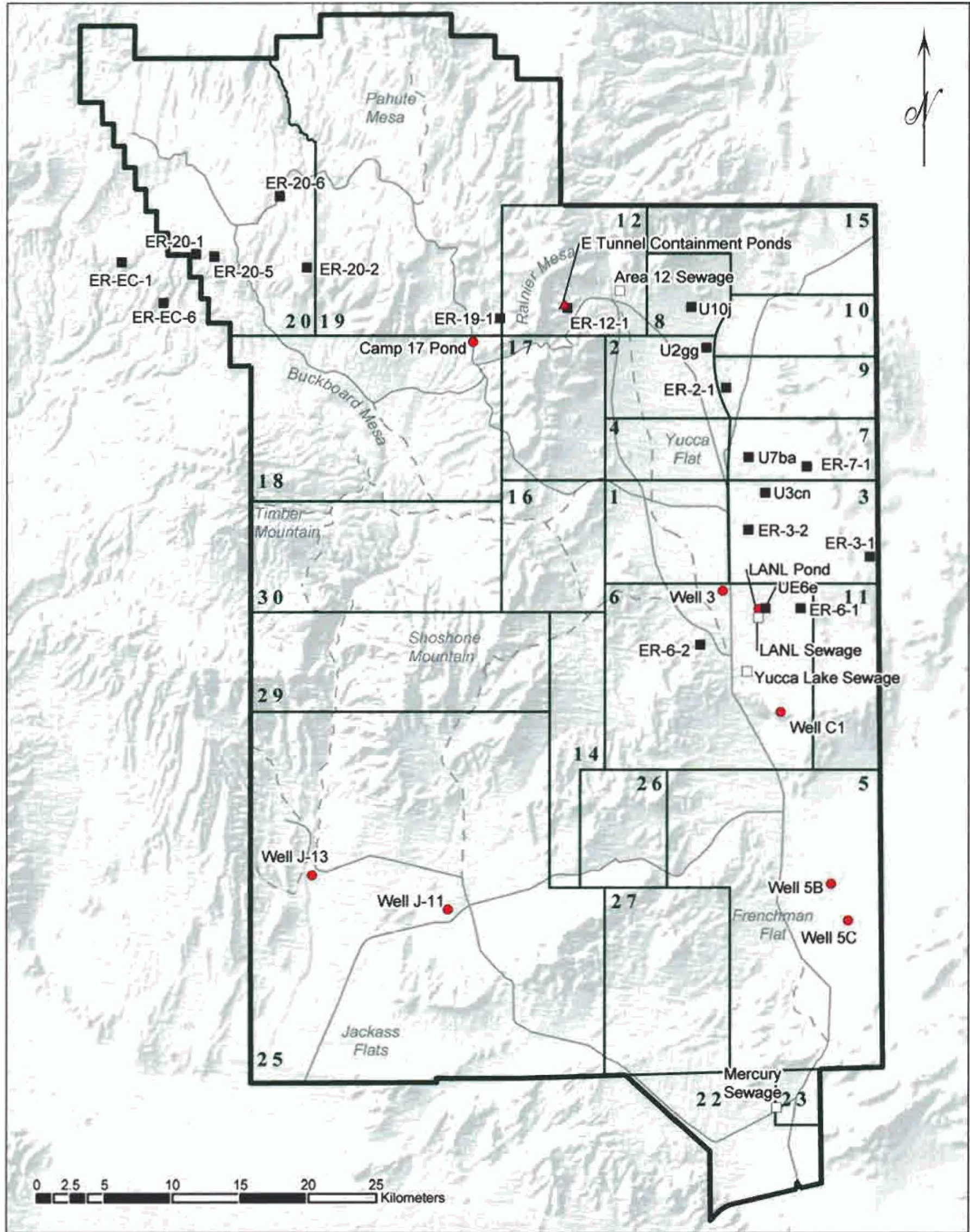

Sewage treatment pond

- Plastic-lined sump
A Radioactive containment pond

- Unlined well pond
Primary Roads

Secondary Roads $\frown$ NTS Operational Areas

NTS Boundary

Figure 21. Man-made water sources monitored for wildlife use and mortality on the NTS during FY 2003 


\subsection{HABITAT RESTORATION MONITORING}

Over the past several decades, some efforts have been made to revegetate disturbed areas on the NTS with native plants (Hunter et al., 1980; 1987; Romney et al., 1989; Wallace and Romney, $1977 ; 1980$; Wallace et al., 1977; 1980). These efforts have been driven by the need to develop viable reclamation techniques in the Mojave Desert which could then be applied to NTS project sites where soil stabilization or habitat reclamation is needed. NNSA/NSO evaluates revegetation as a potential mitigation measure for disturbance to soils on a site-specific basis based on site size, future use, nature of soils, annual precipitation, slope, aspect, and site location (DOE/NV, 1996). To date, the majority of projects for which revegetation has been pursued and funded are abandoned industrial or nuclear test support sites that have been characterized and remediated under the Environmental Restoration (ER) Program. Also, the ER Program has funded revegetation for some soil cover caps to protect against soil erosion and water percolation to buried waste. Revegetation test plots were established in Area 11 to test alternate field methods under scenarios where topsoil would be removed during cleanup of plutonium contaminated sites on and off the NTS. This year funds were provided to revegetate a wildland fire area on the NTS.

Although these efforts were all funded by other programs, one goal of EMAC is to monitor the long-term outcome of both natural vegetation succession and succession by revegetation at disturbed sites throughout the NTS. As opportunities arise, periodic monitoring is conducted to help develop a site-wide habitat restoration plan and better evaluate criteria which influence revegetation success. This year, EMAC supported monitoring of two revegetated areas; a recent (2002) wildland fire burn site and a historical (1993) revegetation test plot site in Area 11.

\subsection{Egg Point Fire Burn Site}

A wildfire of unknown origin burned approximately 300 acres in Area 12 on August 16, 2002 (Figure 22). The fire, named Egg Point, encompassed vegetation within the following three vegetation associations, as per Ostler et al. (2000): Blackbrush-Nevada Jointfir, Singleleaf Pinyon-Black Sagebrush, and Rubber Rabbitbrush-Nevada Jointfir. The majority of plant cover was lost but there did not appear to be any significant impacts to wildlife or to any sensitive plant or animal species. The Nevada Test Site Wildland Fire Management Plan (BN, 2002) prescribes the rehabilitation of land after a fire, mainly for the prevention of future wildland fires, and secondarily for erosion control. Non-EMAC funds were provided by BN to Ecological Services for the procurement of materials and labor needed to meet these rehabilitation goals and to encourage the establishment of native plant species. Rehabilitation efforts included dispersing seeds, planting transplants, and applying a chemical soil stabilizer.

Seeding of the site began in November 2002 and was completed in January 2003. A total of 3,705 pounds of bulk native seed was distributed over the site. Rocky steep areas with little, if any, soil were not seeded. The total area seeded is estimated to be between 230 and 250 acres. Two different seed mixes were used to reseed the burn area. One was developed for the steep upper slopes and the other for the drainages and bottom areas. About 5,000 transplants of native shrubs were planted along drainages in March, 2003. Following seeding, a soil stabilizer was applied to the soil surface at a rate of 150 gallons/acre on the upper slopes, which are more 
susceptible to soil erosion, and at a rate of 100 gallons/acre on the lower, less steep slopes. Fencing to protect new seedlings and transplants from herbivory was not feasible.

Vegetation monitoring of the burn site was conducted in June 2003 to determine if restoration actions were effective in promoting a plant community less prone to future wildland fires. Monitoring focused on assessing the success of seed germination and plant establishment on the steep upper slopes and the lower slopes and bottoms. Line sample transects were randomly located in these areas and plant density was recorded (Figure 23).

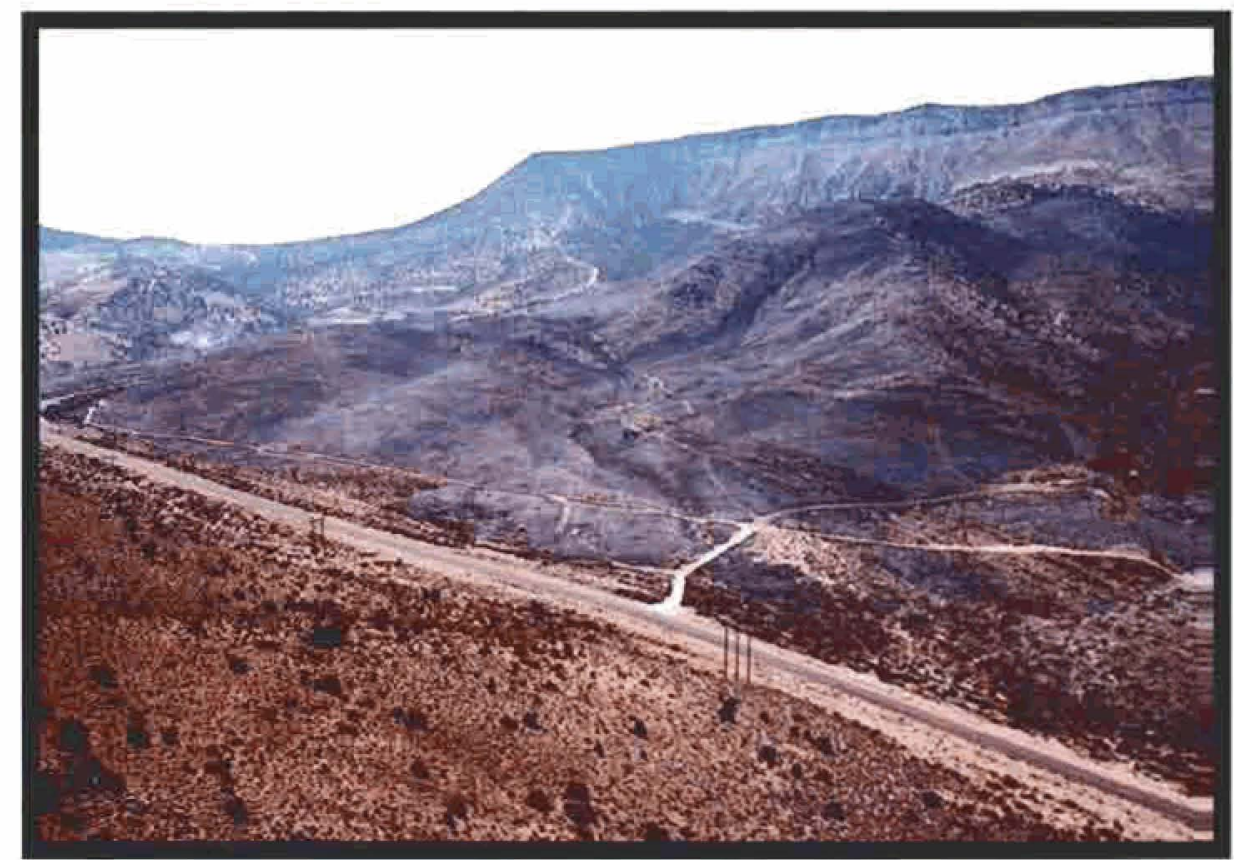

Figure 22. Aerial view of Egg Point Fire site on the lower east-facing slopes of Rainier Mesa (photo by Remote Sensing Laboratory, August 2002)

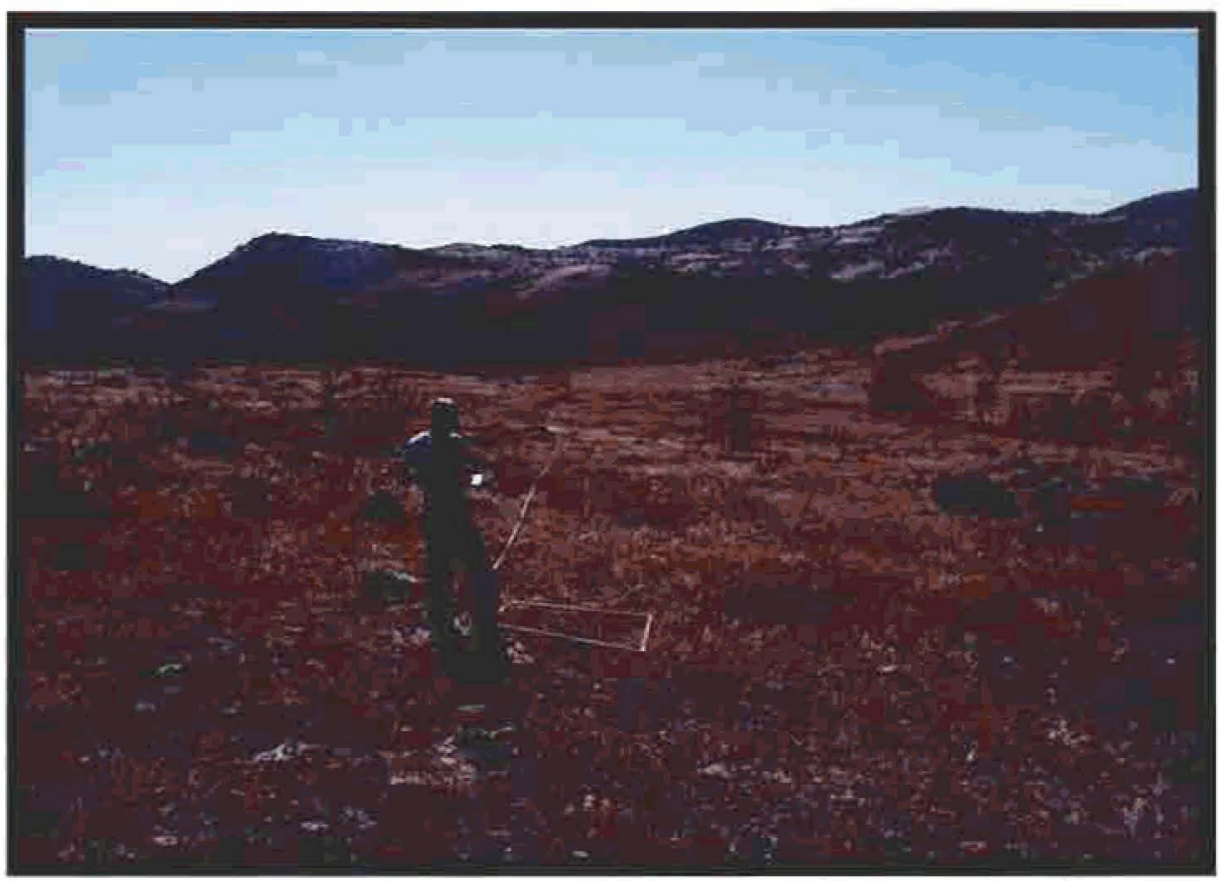

Figure 23. Line transect sampling for plant density of seeded species along lower slopes of Egg Point Fire burn site (photo by W. Kent Ostler, June 2003) 


\subsubsection{Plant Density of Seeded Species}

Plant density on the burn site was low. The continued drought conditions on the NTS and throughout the southwest have not been favorable for seed germination and plant growth. Some areas of the NTS received some early spring precipitation but it was erratic and insufficient. On the upper and lower slopes, total plant density was 8.08 and 5.73 plants $/ \mathrm{m}^{2}$ (plants per square meter), respectively. However, only 0.85 and 1.13 plants $/ \mathrm{m}^{2}$, respectively, were seeded species (Table 13). The other plants were invasive annuals, primarily Bromus rubens (red brome) and B. tectorum (cheatgrass). On the upper slopes, Coleogyne ramosissima (blackbrush) (Figure 24) and Poa secunda (Sandberg's bluegrass) were the most common perennial seeded species, and Eschscholzia californica (California poppy) was the most common annual seeded species. Sphaeralcea grossulariifolia (gooseberryleaf globemallow) is establishing naturally on the site. On the lower slopes, Ericameria nauseosa (rubber rabbitbrush) was the most abundant shrub, and E. californica was the most abundant forb. On both upper and lower slope transects, no Chrysothamnus viscidiflorus (rabbitbrush), Ephedra viridis (mormon tea), or Penstemon seedlings were observed (Table 13). It is expected that seeded species will emerge over the next several growing seasons as soil moisture is replenished in years of higher precipitation.

\subsubsection{Survival of Transplants}

About 5,000 transplants of species native to the burn site were planted in March 2003. Approximately 4,075 of these were "bare root" plants. These are plants that have been commercially grown outside for one to two growing seasons and are then pulled from the soil just prior to shipment. Their root systems are well developed and generally exceed 12 inches in depth and 4 inches in width. The bare root plants included 3,300 Purshia stansburiana (Stansbury cliffrose), 500 Atriplex canescens, and 275 Ephedra viridis (mormon tea). An additional 900 "container-grown" plants were planted. These have been grown in a greenhouse for usually one year in small cylinders of soil (approximately $1 \mathrm{inch}$ in diameter and 10 inches long). Their root systems are much less developed than those of bare root plants. The containergrown plants included 500 Artemisia nova (black sagebrush) and 400 P. stansburiana.

Transplant areas at the burn site were sampled to determine transplant survival and vigor. A representative number of plants of each species was sampled. Plant survival and vigor were recorded for each plant found. Vigor was recorded on a scale from 1 (poor) to 5 (excellent), where 1 indicated the transplant was barely surviving (e.g., no growth, most of its leaves dropped, appeared dessicated) and 5 indicated the transplant was thriving (e.g., new seasonal growth, lush in appearance). Data were summarized by species and by method of propagation (bare root or container-grown). A total of 846 plants were sampled (Table 14) which represents about 17 percent of the total number planted.

After five months, the overall survival of all transplants regardless of propagation method was 75 percent, and overall vigor was 2.1. The highest percentage survival was for bareroot $E$. viridis. Bare root $P$. stansburiana survival was almost double the percentage survival for container- grown $P$. stansburiana. The percentage survival across all species for container grown plants was 64 percent compared to 81 percent for bare root stock. The container-grown A. nova (black sagebrush) (Figure 25) appeared to survive just as well as the other species of bare root plants. Plants will be monitored again next spring or summer to determine how well they survived the hot, dry summer. 
Table 13. Plant densities on the upper and lower slopes of the Egg Point Fire restoration site

\begin{tabular}{|c|c|c|c|}
\hline Seeded Species & Common Name & $\begin{array}{c}\text { Upper Slopes } \\
\text { Density (plants/m²) } \\
\end{array}$ & $\begin{array}{c}\text { Lower Slopes } \\
\text { Density (plants } / \mathbf{m}^{2} \text { ) }\end{array}$ \\
\hline \multicolumn{4}{|l|}{ Shrubs } \\
\hline Artemisia nova & Black sagebrush & 0 & Not Seeded \\
\hline Atriplex canescens & Fourwing saltbush & Not Seeded & 0.06 \\
\hline Chrysothamnus viscidiflorus & Green rabbitbrush & 0 & 0 \\
\hline Coleogyne ramosissima & Blackbrush & 0.11 & 0.05 \\
\hline Ephedra viridis & Mormon tea & 0 & 0 \\
\hline Ericameria nauseosa & Rubber rabbitbrush & 0.05 & 0.31 \\
\hline \multicolumn{4}{|l|}{ Grasses } \\
\hline Achnatherum hymenoides & Indian ricegrass & 0.01 & 0.01 \\
\hline Elymus elymoides & Bottlebrush squirreltail & 0.03 & 0.03 \\
\hline Poa secunda & Sandberg's bluegrass & 0.48 & 0.04 \\
\hline Pleuraphis jamesii & Galleta grass & Not Seeded & 0.06 \\
\hline \multicolumn{4}{|l|}{ Forbs } \\
\hline Linum lewisii & Blue flax & 0.05 & 0.15 \\
\hline Eschscholzia californica & California poppy & 0.17 & 0.42 \\
\hline Penstemon eatonii & Eaton's penstemon & 0 & 0 \\
\hline Penstemon palmeri & Palmer's penstemon & Not Seeded & 0 \\
\hline \multicolumn{2}{|l|}{ Total } & 0.90 & 1.13 \\
\hline \multicolumn{4}{|l|}{ Non-seeded Species } \\
\hline \multicolumn{4}{|l|}{ Forbs } \\
\hline Sphaeralcea grossulariifolia & $\begin{array}{l}\text { Gooseberryleaf } \\
\text { globemallow }\end{array}$ & 0.20 & 0.04 \\
\hline \multicolumn{4}{|l|}{ Grasses } \\
\hline Bromus rubens & Red brome & 5.70 & 2.78 \\
\hline \multirow[t]{2}{*}{ Bromus tectorum } & Cheatgrass & 1.29 & 1.72 \\
\hline & & & 0.06 \\
\hline Total & & 7.19 & 4.60 \\
\hline Grand Total & & 8.09 & 5.73 \\
\hline
\end{tabular}




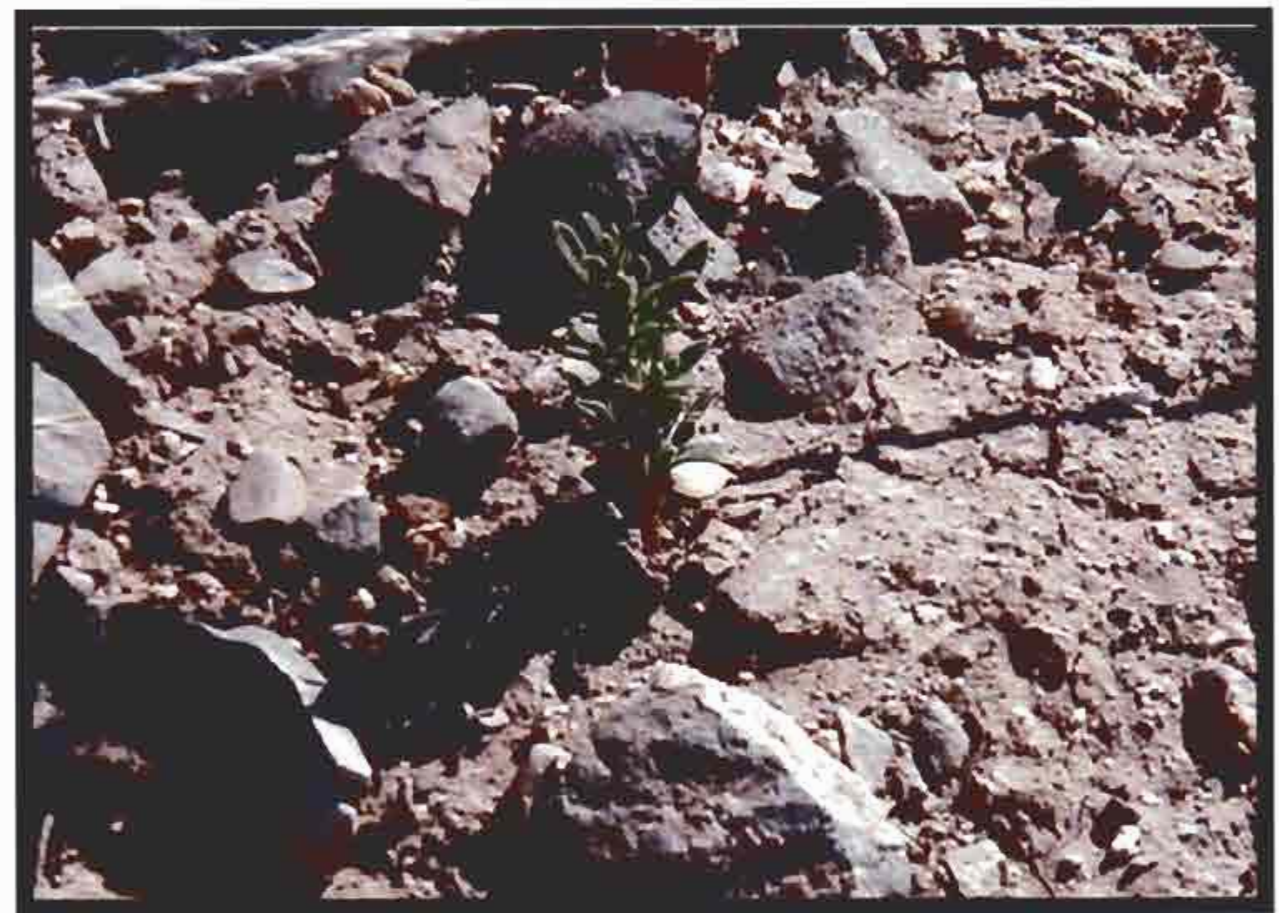

Figure 24. Coleogyne ramosissima seedling observed during line transect surveys at the Egg Point Fire burn site (photo by Derek Hall, June 2003)

Table 14. Survival of transplants planted on the Egg Point Fire restoration site

\begin{tabular}{|c|c|c|c|c|c|}
\hline Species & $\begin{array}{c}\text { Propagation } \\
\text { Method }\end{array}$ & $\begin{array}{l}\text { Number } \\
\text { Sampled }\end{array}$ & $\begin{array}{c}\text { Number } \\
\text { Alive }\end{array}$ & $\begin{array}{l}\text { Percent } \\
\text { Survival }\end{array}$ & $\begin{array}{c}\text { Average } \\
\text { Vigor }^{1}\end{array}$ \\
\hline $\begin{array}{l}\text { Purshia stansburiana } \\
\text { (Stansbury cliffrose) }\end{array}$ & container-grown & 95 & 22 & 23 & 1.7 \\
\hline $\begin{array}{l}\text { Artemisia nova } \\
\text { (black sagebrush) }\end{array}$ & container-grown & 186 & 158 & 85 & 2.2 \\
\hline Total & & 281 & 180 & 64 & 1.8 \\
\hline $\begin{array}{l}\text { Purshia stansburiana } \\
\text { (Stansbury cliffrose) }\end{array}$ & bare root & 451 & 366 & 81 & 2.1 \\
\hline $\begin{array}{l}\text { Ephedra viridis } \\
\text { (mormon tea) }\end{array}$ & bare root & 50 & 48 & 96 & 1.9 \\
\hline $\begin{array}{l}\text { Atriplex canescens } \\
\text { (fourwing saltbush) }\end{array}$ & bare root & 64 & 41 & 64 & 1.9 \\
\hline Total & & 565 & 455 & 81 & 2.1 \\
\hline Grand Total & & 846 & 635 & 75 & 2.1 \\
\hline
\end{tabular}




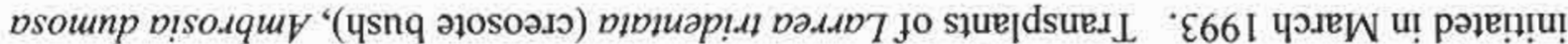

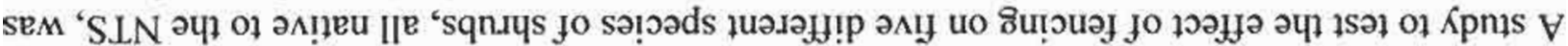

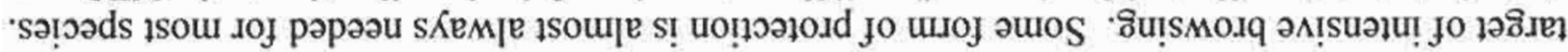

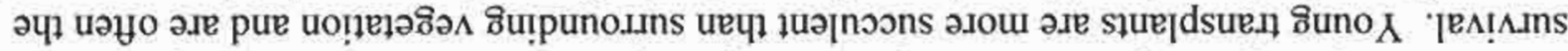

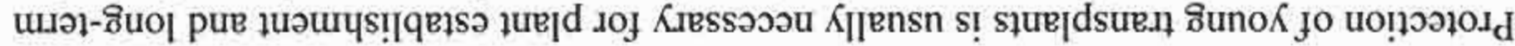

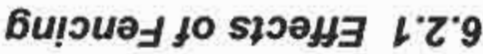

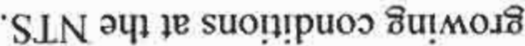

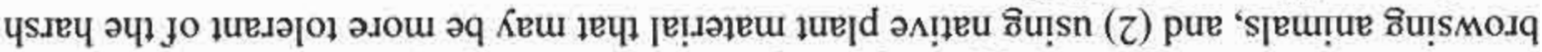

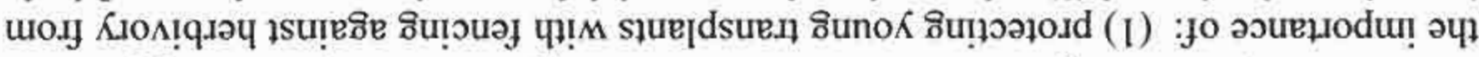

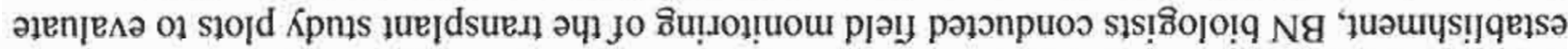

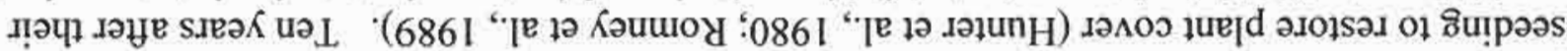

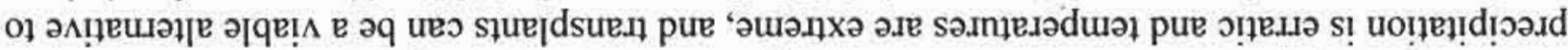
әәәчм цәэә

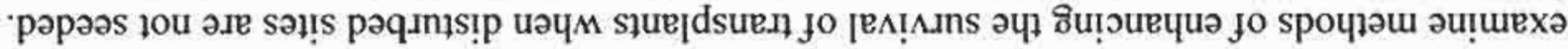

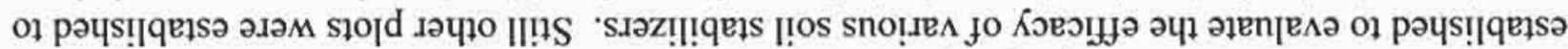

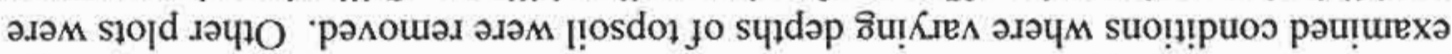

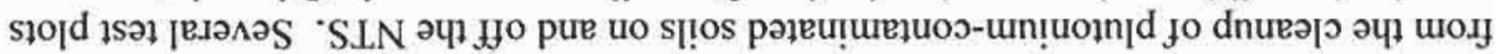

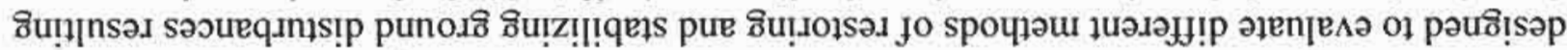

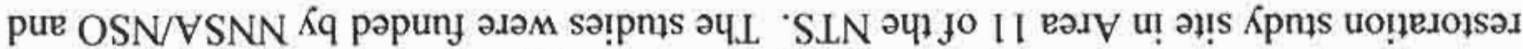

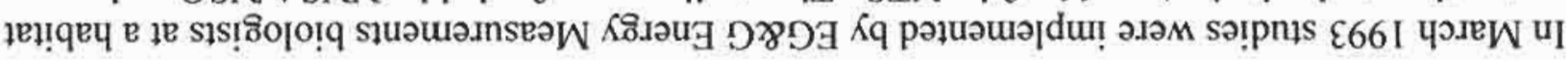

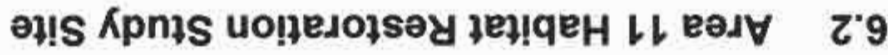

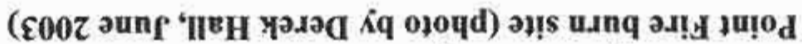

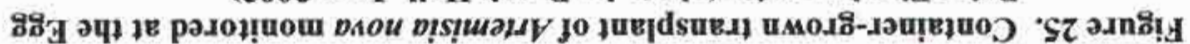

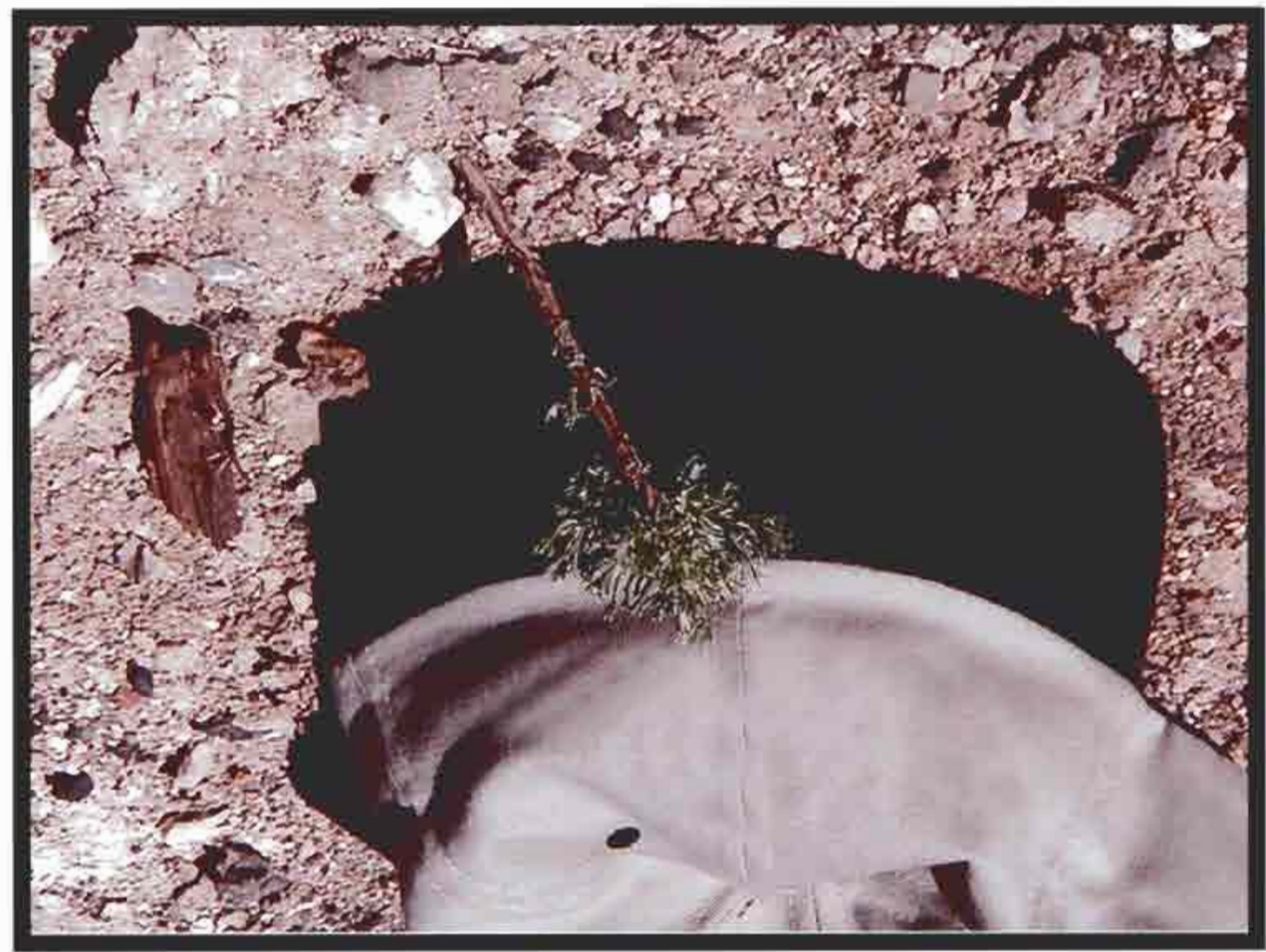


(white bursage), Hymenoclea salsola (white burrobrush), Lycium andersonii (Anderson's wolfberry) and Atriplex canescens (fourwing saltbush) were planted in blocks of ten plants per block with each block being replicated five times for a total of 50 transplants of each species. The blocks of ten transplants were randomly located alongside the fence which encloses the habitat restoration study site. Fifty transplants of each species were planted on the inside of the fence and 50 transplants on the outside. The fence was a poultry wire fence 24 inches high with the bottom 10-12 inches buried below ground. Survival and growth of transplants were evaluated four months after planting, one year after planting, and four years after planting. This year's monitoring examines the effect of fencing ten years after planting. As in past years, plant survival was recorded as was volumetric measurements (height and two widths) of each plant.

After ten years, $L$. tridentata and $L$. andersonii had the highest overall plant survival (Figure 26). $A$. dumosa experienced just less than 50 percent survival. Only one out of five $A$. canescens plants survived and $H$. salsola experienced 98 percent mortality. Fencing appears to provide some protection for $A$. canescens. Percent survival of $A$. dumosa transplants was also higher in the fenced areas but the difference was not as great as it was for $A$. canescens. The greatest mortality for $A$. canescens occurred during the first growing season in the unfenced area. Almost 75 percent of the plants died the first year. Other species only experienced a 5-10 percent rate of mortality the first year. H. salsola appears to be unaffected by fencing. Transplants, whether protected or not, had almost 80 percent mortality by the fourth year and 98 percent by the tenth year. Percent survival for the other three species was about the same inside and outside the fence. Plant growth, as measured by volumetric measurements, reflects slightly different results. Shrub volumes were higher for $A$. dumosa, $A$. canescens, and $L$. andersonii in the fenced area (Figure 27). H. salsola volumes were actually higher where transplants were unprotected.

L. tridentata didn't appear to be affected by fencing as shrub volumes inside and outside the fence were similar.

The use of fencing to protect young transplants from the often fatal effects of herbivory appears to be necessary for $A$. cancescens. This species is very palatable and frequently suffers from overbrowsing. As noted in the percent survival from 1997 to 2003 (Figure 26), there was some resprouting after plants appeared to be dead, but percent survival was still less than plants inside the fence. Those plants that did survive outside the fence were smaller by several orders of magnitude (Figure 27). Although there was some indication that $L$. andersonii benefitted from fencing, the effort to protect transplants by fencing may not be justified for this species.

\subsubsection{Effects of Using Native Plant Material}

It is often argued that native plant material should be used if successful reclamation is to be achieved. These are seeds or transplants collected from an area having the same environmental conditions as the site to be restored and therefore better adapted to those conditions than seeds or transplants collected elsewhere. At the Area 11 habitat restoration study site, two seed sources for L. tridentata, A. dumosa and A. canescens were planted. One source was from the NTS and the other sources were from commercial vendors outside of Nevada. Seeds from both sources were planted in a greenhouse and seedlings were hardened outdoors prior to being planted at the study site. These seedlings were then randomly planted in blocks of ten plants over the Area 11 study site in March 1993. Each treatment was replicated nine times for a total of 540 plants, 90 of each species and seed source. Plant survival and growth were monitored the first few months after 


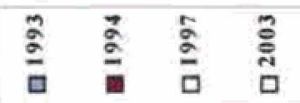

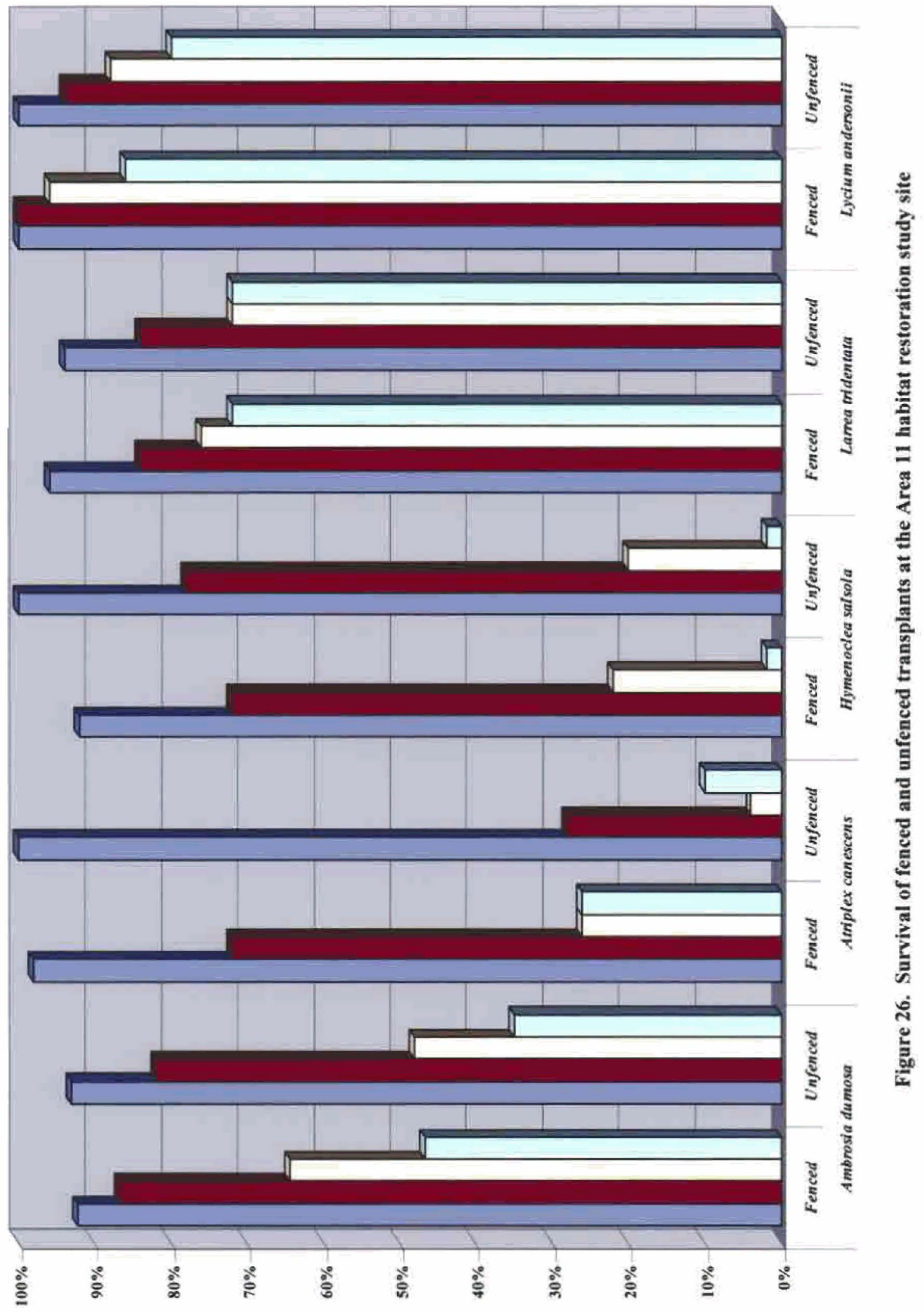


言蓄产言

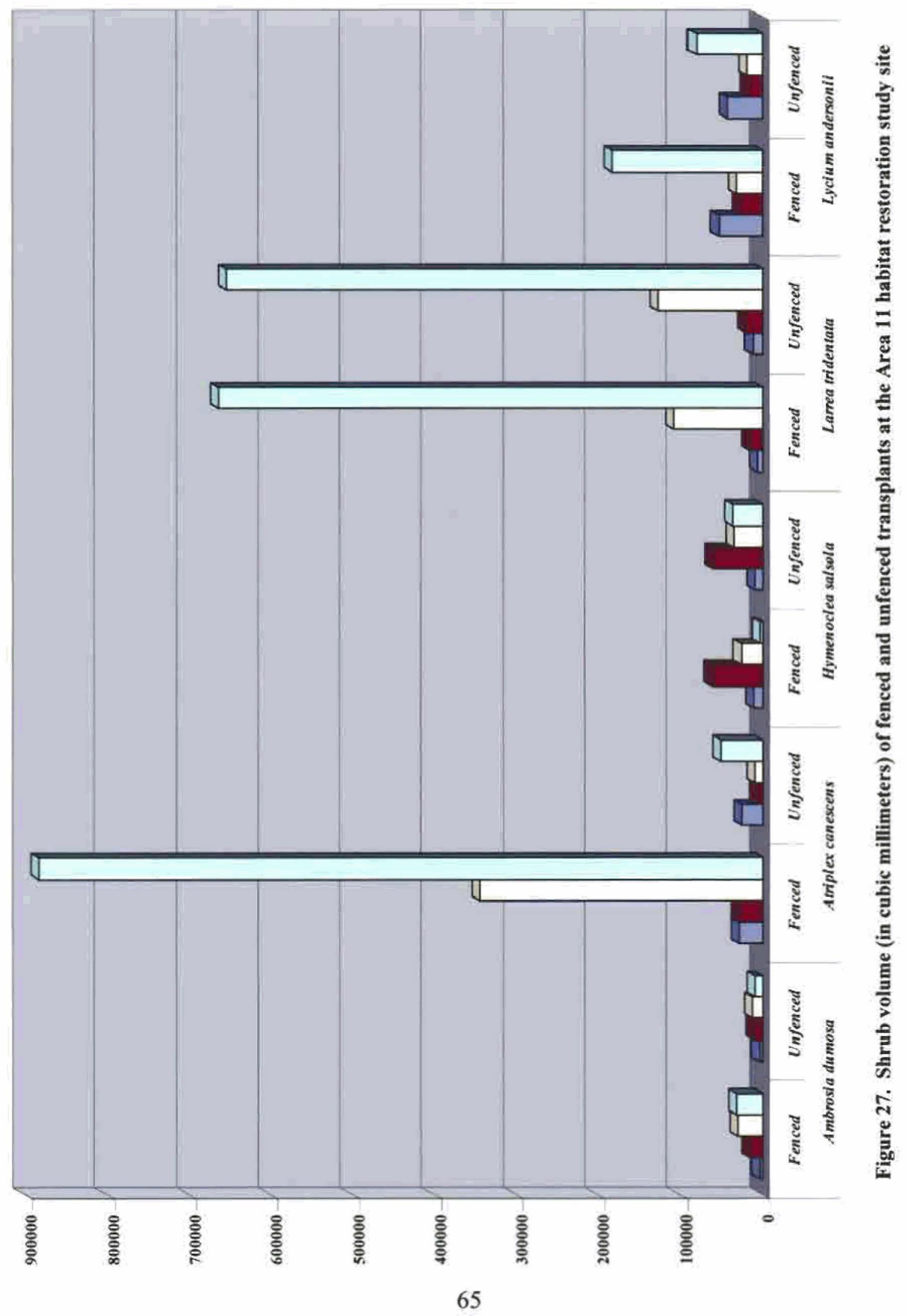


planting in July 1993 and again in 1994 and 1997. This year's monitoring examines the effect of native seed sources ten years after planting. As in past years, plant survival was recorded and volumetric measurements were taken to monitor growth.

The origin of the plant material appears to be an important factor for the survival of $A$. canescens. Percent survival was almost three times greater for transplants of $A$. canescens grown from seed collected on the NTS (Figure 28). Survival for the other species was about the same regardless of seed source. Volumetric data suggests that plant growth may also be affected by origin of seed. Plant growth for $A$. dumosa was about the same for all plants, regardless of seed source.

However, both $A$. cancescens and L. tridentata plants grown from seed collected on the NTS were larger than their counterparts (Figure 29). A. canescens grown from NTS seeds were twice as large as those grown from seed collected in New Mexico, and L. tridentata plants grown from NTS seeds were almost 50 percent larger than plants grown from seed collected in southern Arizona.

It appears that using local seed sources can improve the survival of $A$. canescens transplants and the growth of both $L$. tridentata and $A$. cancescens transplants. Transplants at the Area 11 study site will be monitored in the future in an effort to learn how these species respond to environmental changes such as the recent drought. The information gleaned from these studies will prove to be valuable in developing site-specific reclamation procedures for disturbances on the NTS selected for reclamation. 


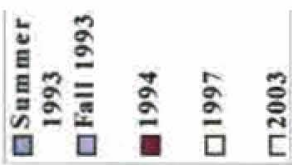

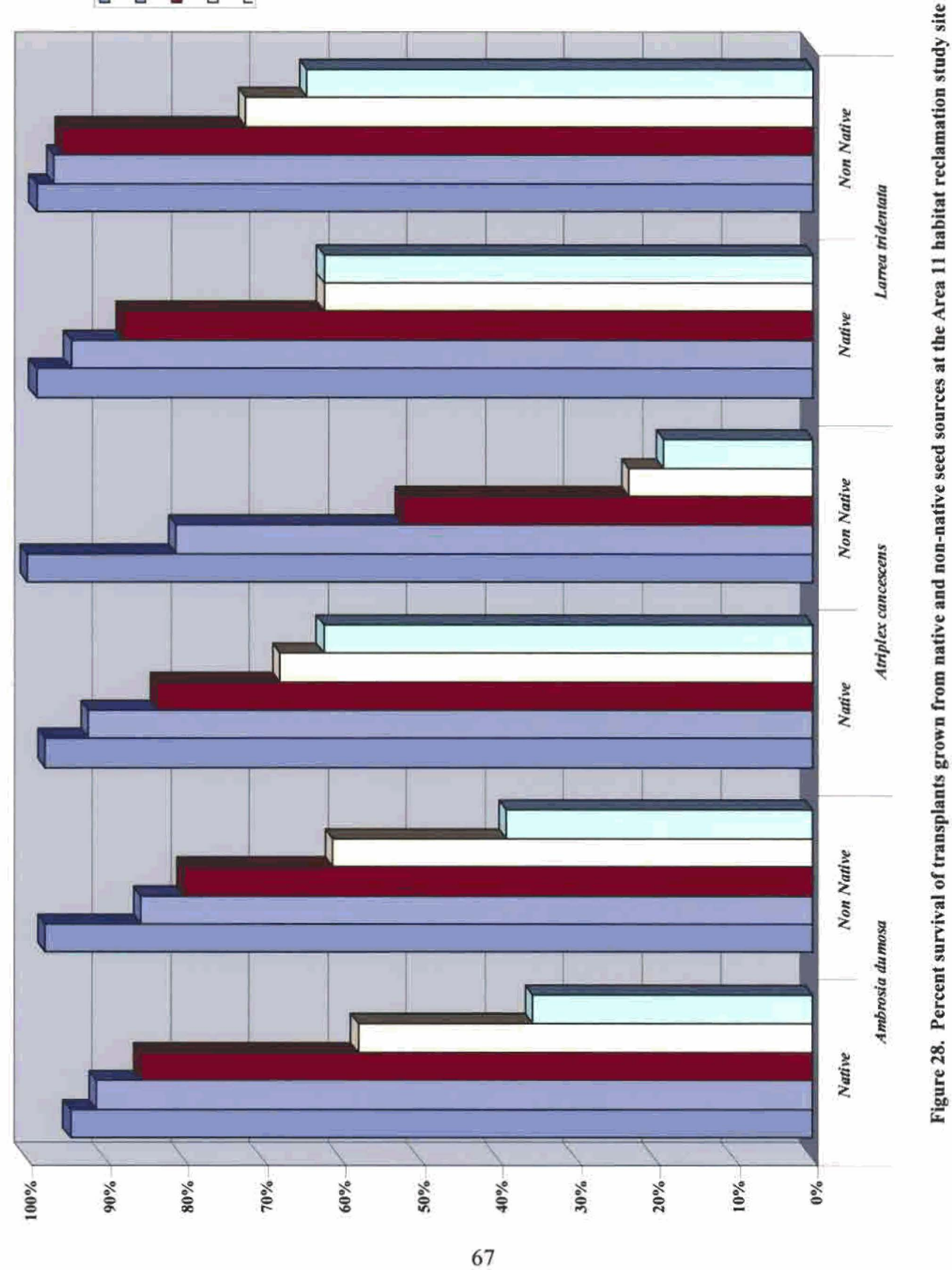




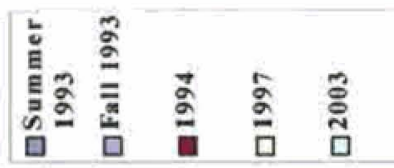

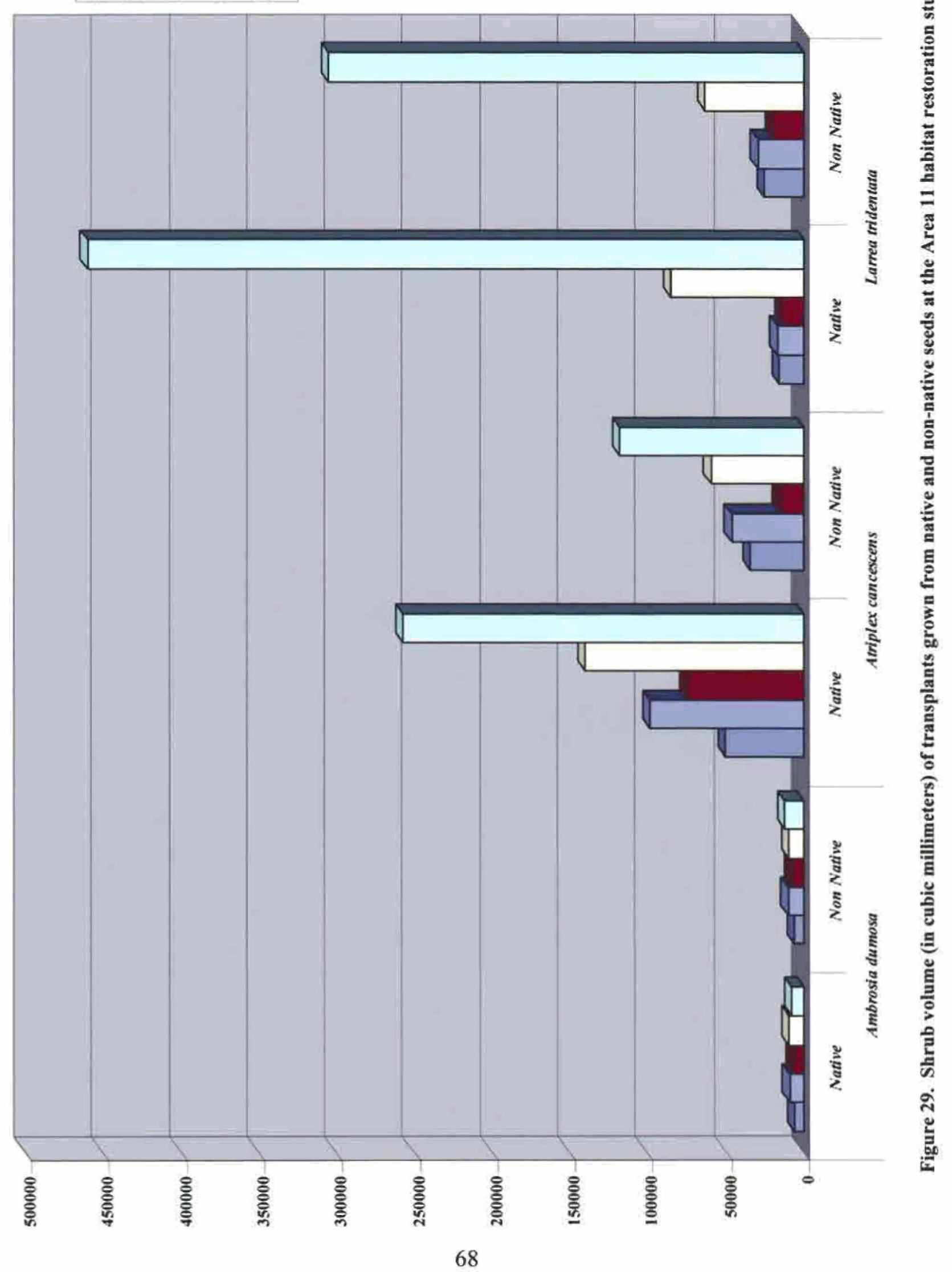




\subsection{MONITORING OF THE HAZMAT SPILL CENTER}

\subsection{Task Description}

Biological monitoring at the HAZMAT Spill Center on the playa of Frenchman Lake in Area 5 will be performed, if necessary, for certain types of chemical releases as per the center's programmatic Environmental Assessment. In addition, ESHD has requested that BN monitor any test which may impact plants or animals downwind which are off the playa. A document titled Biological Monitoring Plan for Hazardous Materials Testing at the Liquefied Gaseous Fuels Spill Test Facility on the Nevada Test Site was prepared in FY 1996 (BN, 1996). It describes how field surveys will be conducted to determine test impacts on plants and animals and to verify that the center's program complies with pertinent state and federal environmental protection legislation. The design of the monitoring plan calls for the establishment of three control transects and three treatment transects at three distances from the chemical release point. The control and treatment transects have similar environmental and vegetational characteristics.

$\mathrm{BN}$ biologists are tasked to review chemical release test plans to determine if field monitoring along the treatment transects is required for each test as per the monitoring plan criteria. All test-specific field monitoring is funded through the HAZMAT Spill Center. Since 1996, the majority of chemical releases being studied at the center use such small quantities that downwind test-specific monitoring has not been necessary.

\subsection{Task Progress Summary}

BN reviewed chemical spill test plans for the following five activities this year: Ground Truth Engineering Tests, Divine Invader, DuPont Fuming Acids Mitigation Workshop, Quail, and Roadrunner II. Chemicals were released at such low volumes or low toxicity that there was no need to monitor downwind transects for biological impacts. Baseline monitoring was conducted at established control-treatment transects near the HAZMAT Spill Center in February and August. This sampling noted the condition of plants and the presence of wildlife sign during the period of vegetative dormancy. No differences in biota were noted along downwind (treatment) versus upwind (control) transects. Baseline monitoring data are collected to document any cumulative impacts over time of test center activities on biota downwind of the facility. These data are made available to neighboring land managers upon request. Noticeable cumulative impacts on biota are not expected. 
THIS PAGE IS INTENTIONALLY LEFT BLANK 


\subsection{LITERATURE CITED}

Altenbach, J. S., W. Amy, P. V. Bradley, P. E. Brown, K. Dewberry, D. B. Hall, J. Jeffers, B. Lund, J. E. Newmark, M. J. O'Farrell, M. Rahn, R. E. Sherwin, C. R. Tomlinson, and J. A. Williams, 2002. Nevada Bat Conservation Plan. Nevada Bat Working Group, Austin, NV. 188 pp.

Bechtel Nevada, 1996. Biological Monitoring Plan for Hazardous Materials Testing at the Liquefied Gaseous Fuels Spill Test Facility on the Nevada Test Site. Submitted to U.S. Department of Energy, Nevada Operations Office, Letter from J. R. Kannard to R. C. Furlow, Correspondence No. E100-JRK-96-004, January 25, 1996.

- 2001. Adaptive Management Plan for Sensitive Plant Species on the Nevada Test Site. DOE/NV/11718-507, Bechtel Nevada, Las Vegas, NV, March 2001.

—, 2002. Nevada Test Site Wildland Fire Management Plan, Revision 0, March 11, 2002. Submitted by letter to T. Wallace, NNSA/NSO from T. Habermas, BN, Correspondence No. A400-TH-02-0005, March 27, 2002.

Berry, K. H., and L. L. Nicholson, 1984. The distribution and density of desert tortoise populations in California in the 1970s. Pages 26-60. In: K. H. Berry (ed.), The Status of the Desert Tortoise (Gopherus agassizii) in the United States. Desert Tortoise Council Report to U.S. Fish and Wildlife Service, Order No. 11310-0083-81, Portland, Oregon.

Blomquist, K. W., C. A. Wills, W. K. Ostler, K. R. Rautenstrauch and T. P. O'Farrell, 1992. Distribution, Life History, Management, and Current Status of Astraglaus beatleyae on the U.S. Department of Energy's Nevada Test Site. EGG10617-2187, EG\&G Energy Measurements, Santa Barbara Operations, Goleta, CA, November 1992.

Blomquist, K. W., T. A. Lindemann, G. E. Lyon, D. C. Steen, C. A. Wills, S. A. Flick, and W. K. Ostler, 1995. Current Distribution, Habitat, and Status of Category 2 Candidate Plant Species on and Near the U.S. Department of Energy's Nevada Test Site. EGG11265-1149, EG\&G Energy Measurements, Las Vegas, NV, December 1995.

BN, see Bechtel Nevada.

DOE/NV, see U.S. Department of Energy Nevada Operations Office.

FWS, see U.S. Fish and Wildlife Service.

Greger, P. D. and E. M. Romney, 1994. Trends in Wildlife Utilization of Water Source and Adjacent Habitats at the Nevada Test Site 1989-91. In: Status of the Flora and Fauna on the Nevada Test Site 1989-91. Compiled by R. B. Hunter, DOE/NV/11432-57, Reynolds Electrical \& Engineering Co., Inc., Las Vegas, NV. 
Greger, P. D. and E. M. Romney, 1999. High foal mortality limits growth of a desert feral horse population in Nevada. Great Basin Naturalist 59:374-379.

Hunter, R. B., E. M. Romney, and A. Wallace, 1980. Fencing enhances srub survival and growth for Mojave Desert revegetation. Great Basin Naturalist Memoirs No. 4:212-215.

Hunter, R. B., E. M. Romney, and A. Wallace, 1987. Revegetation on disturbed desert land at NUWAX and SEDAN. In: The Dynamics of Transuranics and Other Radionuclides in Natural Environments. Howard, W. A., and R. G. Fuller (Eds.). U.S. Department of Energy, Nevada Operations Office, Las Vegas, NV. NVO-272, pp. 79-97.

Klute, D.S, L.W. Ayers, M.T. Green, W.H. Howe, S.L. Jones, J.A. Shaffer, S.R. Sheffield, and T.S. Zimmerman, 2003. Status Assessment and Conservation Plan for the Western Burrowing Owl in the United States. U.S. Department of Interior, Fish and Wildlife Service, Biological Technical Publication FWS/BTP-R6001-2003, Washington, D.C.

NNSA/NV, see U.S. Department of Energy, National Nuclear Security Administration Nevada Operations Office.

Ostler, W.K., D. J. Hansen, D.C. Anderson and D.B. Hall, 2000. Classification of Vegetation on the Nevada Test Site. DOE/NV/11718--477, Bechtel Nevada Ecological Services, Las Vegas, NV.

Peterson, F.F., 1981. Landforms of the Basin \& Range Province Defined for Soil Survey. Technical Bulletin 28, Nevada Agricultural Experiment Station, University of Nevada Reno, January 1981.

Romney, E. M., A. Wallace, and R. B. Hunter, 1989. Transplanting of native shrubs on disturbed land in the Mojave Desert, pp. 50-53. In: Proceedings of the Symposium on Shrub Ecophysiology and Biotechnology; 1987 June 30 - July 2: Logan, UT. Wallace, A., E. D. NcArther, and M. R. Haferkamp (Compilers). General Technical Report INT-256, U.S. Department of Agriculture, Forest Service, Intermountain Research Station, Ogden, UT

Steen, D. C., D. B. Hall, P. D. Greger, and C. A. Wills, 1997. Distribution of the Chuckwalla, Western Burrowing Owl, and Six Bat Species on the Nevada Test Site. DOE/NV/11718-149, Bechtel Nevada, Las Vegas, NV, May 1, 1997.

U.S. Department of Energy, National Nuclear Security Administration Nevada Operations Office, 2002. Nevada Test Site Orthophoto Site Atlas. DOE/NV/11718-604. Geographic Information Systems Section, Remote Sensing Department, Bechtel Nevada, Las Vegas, Nevada.

U.S. Department of Energy Nevada Operations Office, 1996. Final Environmental Impact Statement for the Nevada Test Site and Off-Site Locations in the State of Nevada, Volume 1, Chapters 1-9. DOE/EIS 0243, Las Vegas, NV, August 1996. 
- 1998. Nevada Test Site Resource Management Plan, DOE/NV-518, Las Vegas, NV, December 1998.

, Undated (about 1996). Nevada Test Site Grid Map. ER\&NP Division, EG\&G, Las Vegas, Nevada.

U.S. Fish and Wildlife Service, 1996. Final Programmatic Biological Opinion for Nevada Test Site Activities. File No. 1-5-96-F-33, August 22, 1996, Reno, NV.

Wallace, A. and E. M. Romney, 1977. Initial land reclamation procedures related to possible $\mathrm{Pu}-$ cleanup activities at the Tonopah Test Range. In: Environmental Plutonium on the Nevada Test Site and Environs. White, M. G., P. B. Dunaway, and W. A. Howard (Eds.). NVO-171, Nevada Applied Ecology Group, U.S. Energy Research \& Development Administration, Las Vegas, NV, pp. 65-77.

Wallace, A and E. M. Romney, 1980. The role of pioneer species in revegetation of disturbed desert areas. Great Basin Naturalist Memoirs 4:31-33.

Wallace, A., E. M. Romney, and R. B. Hunter, 1980. The challenge of a desert: revegetation of disturbed desert lands. Great Basin Naturalist Memoirs 4:216-225.

Western Bat Working Group. 1998. Species accounts: ecology, conservation, and management of western bat species. Western Bat Working Group Workshop, February 9-13, 1998, Reno, Nevada 
THIS PAGE IS INTENTIONALLY LEFT BLANK 


\section{DISTRIBUTION}

U.S. Department of Energy, National Nuclear Security Administration Nevada Site Office

Las Vegas, Nevada

Michael Childers, OMD

Carl Gertz, AMEM

Kennith Hoar, ESHD

Deborah Monette, AMNS

Darwin Morgan, OPA

Jay Norman, O/Mgr

Michael Skougard, ESHD (6)

Terry Wallace, AMSSP

Public Reading Facility (1)

Technical Library (1)

\section{U.S. Department of Energy,}

Yucca Mountain Site Characterization Office

Las Vegas, Nevada

Scott Wade

U.S. Bureau of Land Management Las Vegas

Field Office

Las Vegas, Nevada

Mark Morse

U.S. Fish and Wildlife Service, Southern Nevada

Field Office

Las Vegas, Nevada

Cynthia Martinez

Michael Burroughs

Phil Medica

Bechtel Nevada

Environmental Technical Services

Mercury, Nevada

Don Van Etten (8)

Defense Threat Reduction Agency

Mercury, Nevada

Paul Loomis

Desert National Wildlife Range

Las Vegas, Nevada

Richard Birger (3)
Desert Research Institute

Las Vegas, Nevada

David Shafer (3)

DOE Office of Scientific and Technical

Information

Oak Ridge, Tennessee (1 - electronic)

Lawrence Livermore National Laboratory

Las Vegas, Nevada

Rick Higgs

Los Alamos National Laboratory

Las Vegas, Nevada

Jeff Lewis

The Nature Conservancy

Las Vegas, Nevada

Sue Wainscott

Nellis Air Force Base

Las Vegas, Nevada

Deborah Stockdale (2)

Nevada Department of Wildlife, Southern

Region

Las Vegas, Nevada

Sandy Shavinsky

Nevada Division of Forestry

Las Vegas, Nevada

John Jones

Nevada Natural Heritage Program

Carson City, Nevada

Glenn Clemmer

Sandia National Laboratories

Las Vegas, Nevada

Dan Bozman 